\title{
AVALIAÇÃO DOS EFEITOS DA DERIVA GENÉTICA EM DUAS GERAÇÕES DE AMOSTRAGENS NAS POPULAÇÕES DE MILHO BR-105 E BR-106
}

\author{
ROSÂNGELA MARIA PINTO MOREIRA
}

Engenheira Agrônoma

Orientador: Prof. Dr. CLÁUDIO LOPES DE SOUZA JÚNIOR

Tese apresentada à Escola Superior de Agricultura "Luiz de Queiroz", Universidade de São Paulo, para obtenção do título de Doutor em Agronomia, Área de Concentração: Genética e Melhoramento de Plantas

PIRACICABA

Estado de São Paulo - Brasil

Junho -1999 


\section{Dados Internacionais de Catalogação na Publicação (CIP) DIVISÃO DE BIBLIOTECA E DOCUMENTAÇĀO - Campus "Luiz de Queiroz"/USP}

\section{Moreira, Rosângela Maria Pinto}

Avaliação dos efeitos da deriva genética em duas geraçōes de amostragens nas populaçōes de milho BR-105 e BR-106 / Rosângela Maria Pinto Moreira. - -

Piracicaba, 1999.

$120 \mathrm{p}$.

Tese (doutorado) - - Escola Superior de Agricultura Luiz de Queiroz, 1999. Bibliografia.

1. Deriva genética 2. Endogamia 3. Genética de população 4. Melhoramento genético vegetal 5 . Milho $\mathbf{l}$. Título 
A Deus.

Meu esposo Mario David.

Meus filhos Hugo e Bernardo.

Meus familiares

DEDICO 


\section{AGRADECIMENTOS}

À Escola Superior de Agricultura "Luiz de Queiroz" (ESALQ/USP), pela oportunidade concedida.

À Universidade Estadual de Londrina pela oportunidade de realização do doutorado com auxílio do programa PICDT/CAPES.

Ao Professor Dr. Cláudio Lopes de Souza Júnior, que em sua sábia orientação soube conciliar capacidade, dedicação, confiança e amizade.

À todos os membros da comissão julgadora, pela disponibilidade e pelas valiosas contribuições transmitidas.

À todos os professores da ESALQ/USP, que durante este aprendizado contribuíram para o meu crescimento profissional.

À todos os colegas do Curso de Genética e Melhoramento de Plantas, pelo grande companheirismo e convívio diário e em especial aos amigos Juliana Bernardi Ogliari e Derly José Henriques da Silva, pela sincera amizade e estímulo durante o decorrer do curso.

Aos colegas Carlos Alberto Arrabal Arias e Maria Elizabeth Costa Vasconcelos pela colaboração nas análises estatísticas e pela atenção e presteza.

À todos os funcionários do Departamento de Genética, pelo convívio e atenção. Particularmente a Antônio Juscelino Desidério, Ariberto de Oliveira e a José Modualdo Cucolo pelo apoio e indispensável colaboração na condução dos experimentos.

À Eliana M. G. Sabino pela atenção e correção das referências bibliográficas. 
Aos companheiros da Universidade Estadual de Londrina pelo apoio e amizade dedicados para que este trabalho fosse concluído com êxito.

Aos meus familiares, pela terna atenção manifestada.

Ao meu esposo Mario David Moreira, que mesmo nos momentos mais difíceis dedicou-se integralmente à conquisa deste ideal.

Aos demais que, embora não mencionados, contribuíram para a realização deste estudo.

Finalmente, a Deus, que tudo permitiu. 


\section{SUMÁRIO}

Página

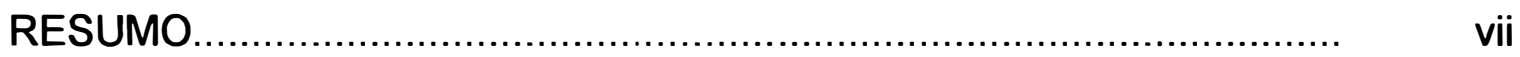

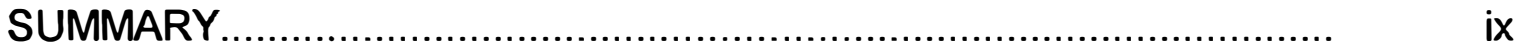

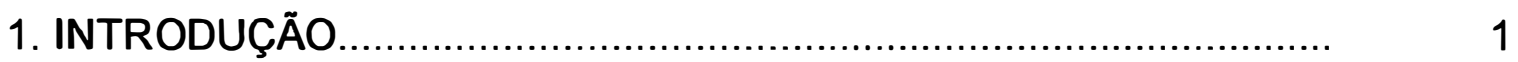

2. REVISÃO DE LITERATURA ...................................................... 3

2.1. Propriedades de populações finitas............................................... 3

2.1.1.Deriva genética................................................................. 5

2.1.2. Endogamia devido ao tamanho reduzido da população............... 11

2.2. Estudos sobre deriva genética................................................... 16

3. MATERIAL E MÉTODOS........................................................ 31

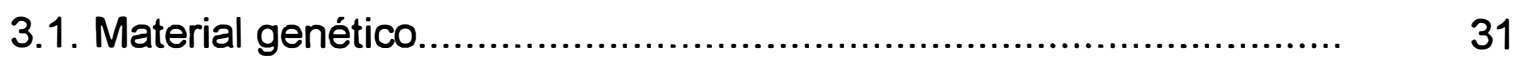

3.2. Procedimentos experimentais................................................... 33

3.3. Análises estatísticas e genéticas............................................. 35

3.3.1. Análises de variâncias..............................................................

3.3.2. Avaliação. da deriva genética................................................. 37

3.3.3. Estimativas de variabilidade fenotípica....................................... 41

4. RESULTADOS E DISCUSSÃO..................................................... 44

4.1. Análises de variâncias............................................................ 45

4.2. Efeitos da deriva genética sobre as médias dos caracteres........... 47

4.3.Estimativas dos efeitos da deriva genética................................... 52

4.4. Efeitos da deriva genética na variabilidade fenotípica das subpopulações. 


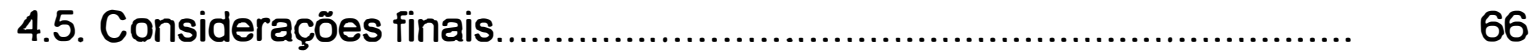

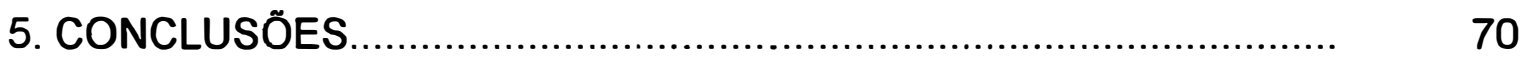

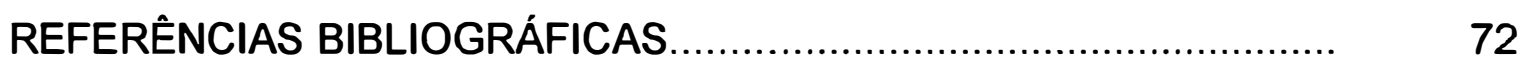

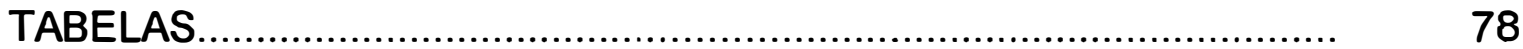

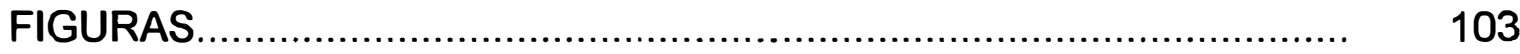




\title{
AVALIAÇÃO DOS EFEITOS DA DERIVA GENÉTICA EM DUAS GERAÇÕES DE AMOSTRAGENS NAS POPULAÇÕES DE MILHO BR-105 E BR-106
}

\author{
Autor: ROSÂNGELA MARIA PINTO MOREIRA \\ Orientador: Prof. Dr. CLÁUDIO LOPES DE SOUZA JÚNIOR
}

\section{RESUMO}

Os objetivos dessa pesquisa foram avaliar os efeitos da deriva genética em milho. Para isso foram obtidas 20 subpopulações em duas gerações sucessivas de amostragem em duas populações -BR-105 e BR-106que possuem estruturas genéticas diferentes. Cada subpopulação em cada geração de amostragem foram formadas com tamanho efetivo populacional $(\mathrm{Ne})$ igual a 5.

Os tratamentos foram constituídos das populações originais BR105 e BR-106, das 20 subpopulações da primeira geração de amostragem, das 20 subpopulações da segunda geração de amostragem e de 7 híbridos comerciais, totalizando 49 entradas. Esses tratamentos foram avaliados em 5 ambientes em látices $7 \times 7$ com oito repetições por ambiente e por não ter havido eficiência na análise em látice, os experimentos foram analisados em blocos casualizados completos.

Os caracteres avaliados foram produção de grãos, altura da planta, altura da espiga, posição relativa da espiga na planta e prolificidade. 
Esses caracteres foram tomados ao nivel de parcelas para se estimar os efeitos da deriva genética sobre as médias dos caracteres. Também, foram avaliados os caracteres produção de grãos, altura da planta e altura da espiga ao nível de plantas para se estimar os efeitos da deriva genética sobre a variabilidade fenotípica e a distribuição de freqüências desses caracteres. Os efeitos da deriva genética sobre as médias foram obtidos através de contrastes entre as médias das subpopulações entre gerações e entre as gerações e as populações de origem.

Efeitos significativos da deriva genética foram detectados para todos os caracteres analisados, sendo observado um maior número de subpopulações com efeitos significativos da deriva genética para o caráter produção de grãos. Isso ocorreu devido ao fato de esse caráter ter um grau médio de dominância superior aos demais caracteres e a deriva genética ser diretamente proporcional ao nível de dominância do caráter.

As populações BR-105 e BR-106 por terem estruturas genéticas diferentes apresentaram comportamentos diferentes em relação aos efeitos da deriva sobre as médias dos caracteres. Sendo que a população BR-105 apresentou maiores amplitudes de variação para o caráter produção de grãos, nas duas gerações de amostragens, em relação a população BR-106.

A deriva genética afetou significativamente, também, a variabilidade fenotípica das subpopulações para os três caracteres avaliados, embora a normalidade das distribuições tenham se mantido. Desta forma, através da amostragem de tamanho efetivo reduzido, pode-se obter subpopulações diferentes da população original. Como a deriva não mantêm a integridade genética das populações, é importante considerar seus efeitos na coleta, manutenção de bancos germoplasma e nos programas de. melhoramento genético. 


\title{
ASSESSMENT OF THE EFFECTS OF GENETIC DRIFT IN TWO SAMPLE GENERATION IN THE BR-105 AND BR-106 MAIZE POPPULATIONS
}

\author{
Author: Rosângela Maria Pinto Moreira \\ Advisor: Prof. Dr. Cláudio Lopes de Souza Júnior
}

\section{ABSTRACT}

The effects of genetic drift were assessed in two maize populations. Twenty subpopulations were obtained in two successive sample generations in populations $\mathrm{BR}-105$ and $\mathrm{Br}-106$ which have different genetic structures. Each subpopulation in each sample generation had an effective populational size $(\mathrm{Ne})$ equal to 5 .

The treatments consisted of the original BR 105 and BR-106 populations, the 20 subpopulations of the first sample generation, the 20 subpopulations of the second sample generation and 7 commercial hybrids, totaling 49 entries. These treatments were assessed in five environments in $7 \mathrm{x}$ 7 lattices with eight replications per environment but because the analysis in lattice was not efficient, the experiments were analyzed as complete randomized blocks.

The grain yield, plant height, ear height, relative position of the ear on the plant and prolificacy were assessed. These traits were taken at plot level to estimate the effects of the genetic drift on their means. The grain yield, 
plant height and height of the ear at plant level traits were also assessed to estimate the effects of the genetic drift on phenotypic variability and the distribution of frequencies of these traits. The effects of the genetic drift on the means were obtained using contrasts among the means of the subpopulations among generations and among the generations and the populations of origin.

Significant genetic drift effects were detected for the traits analyzed. A larger number of subpopulations with significant genetic drift effects were observed for the grain yield trait. This is probably due to a higher mean dominace observed for yield than for the other traits, since the genetic drift is directly proportional to the level of dominance of the trait.

The BR-105 and BR-106 populations showed different behavior from the genetic drift effects on the means of the characters because they have different genetic structures. Population BR-105 showed greater variability range for grain yield, in the two sample generations, comparatively to the population BR-106.

The genetic drift also significantly affected the phenotypic variability of the subpopulations for the three traits assessed, although the normality of the distributions was maintained. Thus, using sampling with reduced effective size caused sub-populations to be different from the original population. As the drift did not maintain the genetic integrity of the populations, it is important to consider their effects on sampling and maintaining germplasm and in breeding programs. 


\section{INTRODUÇÃO}

O nivel de diversidade genética nas espécies cultivadas é função das características biológicas da espécie e dos programas de melhoramento. E para a conservação e manutenção da variabilidade deve-se contar com coleções de germoplasmas representativas de cada espécie. Entretanto, dentro das populações, a variabilidade genética é freqüentemente reduzida ou aumentada em função do tamanho das amostras.

Naturalmente, as espécies cultivadas mostram ter baixo nivel de variabilidade genética em conseqüência das limitações de espaço, tempo, recursos financeiros e esforços, pois nestes casos é sempre interessante utilizar tamanho mínimo de amostra. Assim, em muitas espécies cultivadas, a variação genética da população base é muito limitada ao pequeno tamanho populacional ou a fenótipos distintos que são selecionados. Conseqüentemente, as populações apresentam pequeno número de indivíduos ou pequeno tamanho efetivo, mostrando níveis reduzidos de diversidade e levando a ocorrência da deriva genética.

A deriva genética refere-se as alterações aleatórias das freqüências alélicas de uma população devido ao tamanho da amostra, levando eventualmente, a fixaçaō ou a perda_do alelo À medida_que as subpopulações se distanciam em freqüências alélicas, tornam-se também diferentes pelas freqüências genotípicas, tendo em geral importantes conseqüências. Ocorre redução da variação genética dentro de uma pequena população, pode ocorrer uma diferenciação entre as subpopulações. Mas a diferenciação não é o único aspecto da mudança pois há um aumento na freqüência dos homozigotos, às 
custas de um decréscimo dos heterozigotos que conjugada a tendência geral dos alelos deletérios serem recessivos, é a base da perda da fertilidade e viabilidade (depressão) o que quase sempre resulta da endogamia. De maneira que uma amostra em particular pode não ser representativa da população de origem.. A essa falta de representatividade genética pode se tornar importante em situações onde possam existir alta freqüência de alelos raros (Crow \& Kimura, 1970).

As conseqüências das mudanças aleatórias nas freqüências alélicas são bem conhecidas em populações subdivididas ou em populações pequenas e isoladas (Falconer \& Mackay, 1996). Há contudo, outras causas possiveis: as condições de ambiente provavelmente diferem de uma localidade para outra e de uma estação climática para outra, de tal forma que a intensidade, e a direção da seleção, pode variar de um local para outro e de ano para ano, e as diferenças observadas poderiam ser atribuídas à variação da pressão de seleção (Mettler e Gregg, 1969; Futuyma, 1992). Deve-se ressaltar, então, que o efeito da mudança aleatória nas freqüências alélicas devido a deriva genética, por si só, não é o único fator a provocar alterações na variabilidade. $O$ efeito da seleção também afeta estes parâmetros, devido à reprodução diferencial de genótipos.

Relatos de efeitos da deriva genética em vegetais são raros, especialmente aqueles envolvendo caracteres quantitativos. Estimativas desses efeitos tem sido obtidas em populações de milho sob seleção recorrente (Smith, 1983; Helms et al., 1989; Keeratinijakal \& Lamkey, 1993; Rezende, 1997). Entretanto, essas estimativas estão confundidas com efeitos da seleção e, provalvelmente, não refletem os reais efeitos da deriva genética.

Devido à importância da deriva genética para a coleta, manutenção de coleções de bancos de germoplasma e para os programas de melhoramento, realizou-se esta pesquisa cujo objetivo é a avaliação dos efeitos desse fenômeno em caracteres quantitativos em duas populações de milho. 


\section{REVISÃO DE LITERATURA}

\subsection{Propriedades de populações finitas}

O princípio de Hardy-Weinberg é um dos fundamentos da genética de populações e, em essência, postula que na ausência de seleção, mutação e migração, as freqüências alélicas e genotípicas permanencem constantes, geração após geração para populações de tamanho infinito, e acasalamento aleatório. Na realidade, entretanto, as populações têm tamanho finito e o acasalamento pode ocorrer, de modo não aleatório.

Toda população é uma entidade finita, por maior que seja; dessa forma, portanto, o máximo que se pode ter, em condições naturais, são estados próximos ao equilíbrio. Ademais os indivíduos de uma dada geração são formados de $2 \mathrm{~N}$ gametas da geração precedente, e esses somente representam exatamente o reservatório gênico da população quando $\mathrm{N}$ é infinito. Conclui-se, pois, que os gametas carregam apenas uma amostra do reservatório gênico de uma população $e$, por isso, estão sujeitos a erros de amostragem quando $\mathrm{N}$ é finito. Os gametas, que transmitem genes para a geração seguinte, carregam a amostra de genes da geração parental, 
e șe a amostra não for suficientemente grande, as freqüências alélicas estarão sujeitas a modificações entre esta geração e a seguinte. Quanto menor o tạmanho da população e, portanto, o tamanho da amostra de gametas, maior fica sendo a influência da variação devida à amostragem.

O termo "acasalamentos ao acaso", se considerado com rigor, só pode ser aplicado a sistemas de acasalamentos onde cada membro da população tem a mesma probabilidade de produzir descendentes e que cada gameta feminino deve ter igual probabilidade de ser fertilizado por qualquer gameta masculino (Allard, 1971). Entretanto, dificilmente isto deve ocorrer em condições naturais, pois sempre existe alguma forma de seleção ocorrendo. $E$ um desvio comum do acasalamento ao acaso ocorre quando este é mais provável entre indivíduos aparentados que entre aqueles que não o são. Uma das principais razões para que isto ocorra é que a capacidade de dispersão é limitada na maioria das espécies, de modo que os acasalamentos têm maior probabilidade de se realizarem entre genótipos com algum grau de parentesco.

Assim, essa propriedade de estabilidade das freqüências alélicas não se mantém em uma pequena população e essas freqüências são sujeitas a flutuações (aumento ou redução) ao acaso, originadas pela amostragem de gametas. Essa mudança ao acaso das freqüências alélicas é denominado de processo dispersivo, ou deriva genética, por meio dos quais a freqüência alélica pode ser mudada, mas difere dos processos sistemáticos (mutação, seleção e migração) por ser ao acaso em direção e predito somente em quantidade (Falconer \& Mackay, 1996).

Esse processo dispersivo tem, de modo geral, três importantes conseqüências. A primeira é a diferenciação entre subpopulações. Na natureza os habitantes de uma grande área constituem raramente uma grande e única população, porque os acasalamentos ocorrem, mais freqüentemente, entre habitantes da mesma região. Populações naturais são, portanto, mais ou menos subdivididas em grupos locais ou subpopulações, e o processo amostral tende a causar diferenças genéticas entre elas, se o número de indivíduos do 
grupo é pequeno. Populações domesticadas, ou de laboratório, do mesmo modo, são muitas vezes subdivididas, como, por exemplo entre rebanhos ou linhagens e nelas a subdivisão e a diferenciação resultante é frequentemente, mais marcante. A segunda conseqüência é reduzir a variação genética dentro de uma pequena população. Os indivíduos da população tornam-se, gradualmente, mais semelhantes, e a uniformidade genética é a razão do uso difundido de linhagens endogâmicas de animais e plantas. A terceira conseqüência do processo dispersivo é o aumento na freqüência de homozigotos, às custas de um decréscimo de heterozigotos. Essa última , conjugada com a tendência geral de alelos deletérios serem recessivos, é a base genética da perda da fertilidade e viabilidade (depressão), o que quase sempre resulta da endogamia (Falconer \& Mackay, 1996; Futuyma, 1992).

\subsubsection{Deriva genética}

Deriva genética refere-se às alterações nas freqüências alélicas de uma população devido ao tamanho da amostra. Desde que a essas alterações da freqüência alélica é acumulativa e relativamente permanente, a deriva pode ocorrer não somente em populações permanentemente pequenas mas também naquelas que ficam pequenas só periodicamente ("efeito de afunilamento"), e pode também ocorrer naquelas que são pequenas desde seu princípio, isto é, as constituídas por poucos imigrantes, ou fundadores, e que carregam uma pequena porção de variação genética de uma população maior ("princípio dos fundadores") (Metter \& Gregg, 1973). Assim, se for utilizada uma amostra pequena de uma população alguns genótipos podem não ser amostrados e, consequentemente, alguns alelos podem ser perdidos durante 0 processo amostral, principalmente aqueles cujas freqüências são baixas. 
A subdivisão de uma população pode ser provocada, por causas geográficas ou ecológiças, sob condições naturais, ou por condições experimentais utilizando-se de acasalamentos controlados. Todas as subpopulações, em conjunto, constituem a população completa e cada subpopulação é uma "pequena população", na qual as freqüências alélicas estão sujeitas a deriva genética. $O$ que acontece aos alelos de um loco, entre subpopulações, ocorre também, aos alelos em um número de locos em uma subpopulação, mas, para isso é necessário que os locos se iniciem com a mesma freqüência alélica e não estejam ligados. Então, as conseqüências da deriva aplicam-se igualmente a uma subpopulação somente, desde que sejam considerados muitos locos nela.

Para melhor entender a deriva genética, pode ser considerada como exemplo uma população em equilíbrio de Hardy-Weinberg sendo essa população subdividida em um grande número de subpopulações, cada uma com $N$ indivíduos reprodutores ( $2 N$ genes). $O$ valor $N$ corresponde ao número de individuos que participam da reprodução genética na população, incluindo, assim, somente aqueles indivíduos que efetivamente contribuem com genes para a próxima geração. Este conceito define o número efetivo de indivíduos genéticos ou tamanho efetivo da população ( $\mathrm{Ne}$ ). O tamanho efetivo é diferente, geralmente menor que o tamanho físico (número de sementes, número de mudas, número de plantas, número de animais). $\mathrm{O}$ conceito de tamanho efetivo populacional foi introduzido por Wright (1931) e seu cálculo e importância foi discutido por diversos autores, (Cabalero, 1994; Crow \& Kimura, 1970; Nei \& Tajima, 1981).

Considerando um loco qualquer com alelos $A$ e $A^{\prime}$ cujas freqüências são $p$ e $q$, respectivamente, e que são retiradas diversas subpopulações de tamanhos iguais, a variância (deriva) das freqüências. alélicas destas subpopulações é dado por (Falconer \& Mackay, 1996): 


$$
\sigma_{\delta \mathrm{p}}^{2}=\frac{p_{0} q_{0}}{2 N e}
$$

Essa variância expressa a mudança esperada em qualquer subpopulação, ou a variância da freqüência alélica que seria encontrada entre muitas subpopulações que tornaram-se diferentes em freqüências alélicas, embora a média permaneça inalterada . Portanto, a deriva genética é um processo dispersivo, onde em cada subpopulação, a freqüência de um determinado alelo é igual a freqüência deste na população de origem distribuídas em torno dessa média de acordo com sua dispersão, isto é, $p \pm \sqrt{\frac{p q}{2 N e}}$.

Observa-se, que a deriva genética é inversamente proporcional ao tamanho da subpopulação ( $\mathrm{Ne}$ ); portanto, quanto maior o tamanho, menor será a magnitude de $\sigma_{\delta p}^{2}$. Isso significa que quanto maior o tamanho da subpopulação, maior é a probabilidade das freqüências alélicas da amostra estarem próximas da população de origem, $e$ as perdas de alelos, principalmente aqueles cujas freqüências são baixas, são minimizadas.

À medida que ocorre deriva genética, a variação entre as subpopulações aumenta de geração a geração. Entre as subpopulações, algumas irão ter sua freqüência alélica aumentada $e$, outras, diminuída, havendo, portanto, uma expansão na gama de freqüências alélicas . A variância na freqüência alélica entre as subpopulações em qualquer geração $t$ será : (Crow, 1954)

$$
\sigma_{\delta \mathrm{p}_{\mathrm{t}}}^{2}=p_{0} q_{0}\left[1-\left(1-\frac{1}{2 N e}\right)^{t}\right]
$$

O efeito da amostragem continuada, por meio de gerações sucessivas, faz com que cada subpopulação flutue irregularmente em termos 
das freqüências alélicas, tornando-se progressivamente diferenciada das demais, o que caracteriza a deriva genética (Wrigth, 1931).

Após algum tempo, a distribuição das freqüências alélicas poderá ser tão ampla que todas as freqüências alélicas possiveis entre 0 e 1 estarão igualmente representadas entre as subpopulações e algumas dessas poderão atingir as freqüências 0 e 1 . Quando $p=1$, diz-se que o alelo $A$ está fixado e a população é monomórfica, $A A$. Quando $p=0$, o alelo $A^{\prime}$ está fixado. Entretanto, se um dos alelos foi fixado, o outro alelo somente estará presente novamente quando ocorrerem mutações ou através do fluxo gênico de outras populações. As populações polimórficas remanescentes continuam a variar no intervalo de 0 e 1 e, em cada geração, $1 / 2 N$ indivíduos em cada subpopulação terá fixado $A$ ou $A^{\prime}$. Eventualmente, todas as subpopulações irão fixar um ou outro alelo e a variância na freqüência alélica torna-se $p g$. Claramente, o alelo com maior freqüência no início tem maior chance de se fixar, pois a probabilidade de que um alelo seja fixado é precisamente sua freqüência inicial, $p$. Assim, uma fração $p$ das subpopulações torna-se-á monomórfica $A A$ e uma fração $q=1-p$, monomórfica $A^{\prime} A^{\prime}$. A proporção entre o número de subpopulações em que há fixação e o número em que há perda, está diretamente relacionado com a proporção entre $p$ e $q$. Os heterozigotos estarão ausentes ao se completar a fixação (Futuyma, 1992).

Robertson (1952) mostrou para o caso de um alelo favorável e recessivo, que a medida que as gerações de amostragens se sucedem, a variância genética dentro das amostras aumenta até atingir o máximo quando o coeficiente de endogamia $F=0,5$ e tende a zero e é nula quando $F=1,0$. Neste ponto, uma proporção $p$ das amostras terão fixado o alelo favorável e uma proporção $q$ terão fixado o alelo correspondente.

Quando se está interessado na obtenção da uniformidade genética, deseja-se saber quanto tempo é necessário para que se processe a fixação e qual a probabilidade de um loco particular estar fixado, ou qual a proporção de todos os locos fixados em uma subpopulação, depois de certo 
número de gerações. A consideração da natureza progressiva da dispersão, mostra que a fixação pode não se iniciar imediatamente e alguma dispersão das freqüências alélicas deve ocorrer antes que qualquer subpopulação tenha probabilidade de atingir a fixação. Existem duas fases no processo dispersivo. Durante a fase inicial, as freqüências alélicas estão se distanciando do valor inicial. Isso conduz a uma segunda fase, estacionária, que ocorre quando as freqüências alélicas $p$ e $q$ estão dispersas entre os dois limites 0 (zero) e 1, e todas as freqüências alélicas, exceto os 2 limites, são igualmente prováveis (Falconer \& Mackay, 1996).

A probabilidade de fixação, em qualquer momento, durante a fase inicial da deriva genética é muito complexa, e não convém aos objetivos do presente trabalho, mas são apresentadas por Kimura $(1954,1955)$ e Crow \& Kimura (1970). O tempo médio para perda de alelos, outra informação muito importante, é apresentada por Holdem \& Williams (1994).

O processo da deriva genética pode ser visto como uma flutuação aleatória na freqüência alélica, levando, eventualmente, a fixação ou à perda do alelo. À medida que as subpopulaçōes se distanciam em freqüências alélicas, tornam-se também diferentes pelas freqüências genotipicas. Mas diferenciação não é o único aspecto da mudança, pois a direção geral da alteração é para um aumento na freqüência de homozigotos e um decréscimo de genótipos heterozigotos. A razão disso é a dispersão das freqüências alélicas, afastando-se dos valores intermediários, em direção aos extremos. Os heterozigotos são mais freqüentes quando as freqüências alelicas são intermediárias. Portanto, o afastamento das freqüências alélicas, em direção aos extremos, conduz, em média, a um descréscimo na freqüência de heterozigotos.

As freqüências genotipicas na população total podem ser obtidas a partir do conhecimento da variância das freqüências alélicas. E para um loco com 2 alelos é (Falconer \& Mackay, 1996) (Tabela 1): 


\begin{tabular}{|c|c|}
\hline Genótipo & Freqüênciana_população.toda \\
\hline AA & $p_{0}^{2}+\sigma_{\delta \mathrm{p}}^{2}$ \\
\hline$A^{\prime} A^{\prime}$ & $2 p_{0} q_{o}-2 \sigma_{\delta \mathrm{p}}^{2}$ \\
\hline$A^{\prime} A^{\prime}$ & $q_{0}^{2}+\sigma_{\delta p}^{2}$ \\
\hline
\end{tabular}

Essas freqüências genotípicas não são mais as freqüências esperadas em uma população em equilíbrio de Hardy-Weinberg. Esse fato ocasiona alguma dificuldade, quando se relacionam freqüências alélicas e genotipicas em populaçōes naturais, porque elas são, muitas vezes, mais ou menos subdivididas e o grau de subdivisão é raramente conhecido (Falconer \& Mackay, 1996; Futuyma, 1992).

A consideração que se fez sobre as freqüências genotipicas descreve a situação em termos de um loco em muitas subpopulações. Pode ser vista do mesmo modo como se referindo a muitos locos, em uma subpopulação. Assim, a modificação dentro de uma subpopulação qualquer ou pequena população é um incremento no número de locos em homozigose, e um decréscimo correspondente no número de locos em heterozigose. Essa mudança nas freqüências genotípicas, resultante do processo dispersivo, é a base genética do fenômeno da depressão atribuída à endogamia.

O processo ocorre em toda população finita, mas é tanto mais rápido quanto menor a população. A deriva genética apresenta numerosas conseqüências, três das quais merecem ênfase especial: a deriva genética resulta na perda de variação genética dentro das populações (uniformidade genética); há uma redução geral dos heterozigotos, simplesmente porque nas freqüências alélicas extremas, resultantes das variações aleatórias, a proporção de heterozigotos é menor que nas freqüências alélicas 
intermédiárias; e uma divergência genética entre elas, dependendo do alelo que se torna mais raro ou mais frequente em cada uma (diferenciação de subpopulações), inteiramente ao acaso (Futuyma, 1992).

\subsubsection{Endogamia devido ao tamanho reduzido da população}

A endogamia é causada pelo acasalamento entre indivíduos aparentados. Assim ela pode ocorrer de duas formas, pelos melhoristas ou não, intencionalmente causada pelo tamanho reduzido da população. Neste caso, os indivíduos da população tornam-se aparentados o que acarreta o desenvolvimento da endogamia.

A endogamia resulta do acasalamento de indivíduos que são relacionados por ascendência. Os acasalamentos em pequenas subpopulações, por serem restritos, resultam na união de indivíduos aparentados entre si devido ao fato do maior grau de parentesco entre os genitores do que nas grandes populações, apesar de os acasalamentos serem ao acaso. Devido a isso, as populações de tamanho efetivo pequeno tendem a ser endogâmicas.

Indivíduos endogâmicos podem carregar, em um loco, dois alelos que são réplicas de um mesmo alelo de alguma geração anterior. A consideração dessa conseqüência da endogamia mostra que existem dois tipos de identidade entre alelos e dois tipos de homozigotos. Se estes dois alelos são idênticos por descêndencia, ou seja, derivados por replicação do DNA de um único alelo na população ancestral que originou o indivíduo endógamo, então o indivíduo é denominado autozigótico para este loco. Se os dois alelos são cópias de um mesmo alelo (porém não são replicação do DNA de um único alelo) da geração ancestral, eles são denominados alelos independentes e o indivíduo seria alozigótico para aquele loco. A identidade por ascêndencia 
proporciona base para mensuração do processo dispersivo, mediante 0 grau de parentesco entre os pares acasalados. A medida é o "coeficiente de endogamia", que é a probabilidade de dois alelos em qualquer loco, num individuo, serem idênticos por descêndencia. Isso se refere a um individuo e expressa o grau de parentesco entre os pais desse indivíduo. Se os genitores se acasalaram ao acaso, o coeficiente de endogamia da progênie é a probabilidade de dois gametas da geração paterna, tomados ao acaso, portarem genes idênticos em um loco.

Deve-se mencionar que este conceito somente é válido quando existe especificação de algum ponto no passado, no qual todos os alelos presentes na população são considerados independentes, ou seja, não idênticos por descendência. Este ponto representa a população de origem, e, por definição, tem um coeficiente de endogamia igual a zero. Em determinada geração subsequente, o coeficiente de endogamia expressa a magnitude total do processo dispersivo que vem ocorrendo, desde a população de origem. Para se deduzir o coeficiente de endogamia em gerações sucessivas, parte-se da população de origem (geração zero) e de sua progênie (geração 1).

Todos os alelos de um loco na população de origem têm de ser considerados como não idênticos e deste modo, considerando-se apenas um loco e espécies diplóides, existem $2 \mathrm{Ne}$ tipos diferentes de gametas, igualmente freqüentes, produzidos pela população de origem e que levam os possiveis múltiplos alelos em um loco. Os gametas do mesmo tipo portam alelos idênticos e os tipos diferentes portam alelos de origem independentes. A probabilidade de um par de gametas, tomados ao acaso, carregar alelos idênticos, isto é, o coeficiente de endogamia da primera geração é $F=1 / 2 \mathrm{Ne}$. Na geração $t$, há dois tipos de endogamia: a endogamia adicional, originada de novas duplicações de DNA, que por analogia com a geração anterior corresponde a 1/2Ne; e a endogamia remanescente da geração t-1, que é 
equivalente ao produto da probabilidade de dois gametas carregarem alelos independentes na geraçãot $\left(-1-\frac{1}{2 \mathrm{Ne}}\right)-$ peta-endogamia da geração-anterior $\left(F_{t-1}\right)$. Portanto, o coeficiente de endogamia na geração t é (Falconer \& Mackay, 1996):

$$
F_{t}=\frac{1}{2 N e}+\left(1-\frac{1}{2 N e}\right) F_{t-1}
$$

Portanto, o coeficiente de endogamia é composto de duas partes: um incremento, $1 / 2 \mathrm{Ne}$, atribuivel à nova endogamia, e uma parte restante, atribuivel à endogamia pré-existente, representada pelo coeficiente de endogamia da geração anterior.

É interessante neste ponto,-introduzir o conceito de depressão endogâmica. Como comentado anteriormente, o acasalamento entre indivíduos aparentados provoca aumento da homozigose e decréscimo da heterozigose na descendência. Esses fatos permitem que alelos recessivos de efeito desfavorável, mascarados pelos respectivos dominantes na antiga condição de heterozigose, se manisfestem em homozigose, causando uma redução no valor adaptativo do indivíduo, denominada "depressão ou perda de vigor por endogamia". A quantidade ou número desses alelos desfavoráveis é chamada "carga genética". Portanto, quanto maior a carga genética, maior a depressão por endogamia (Vencovsky \& Barriga, 1992). Deve-se mencionar, contudo, que a redução na heterozigose, por si só, também leva a depressão por endogamia, em função da perda de interações alélicas favoráveis (dominância e/ou sobredominância), independentemente da presença de "carga genética" (Hallauer \& Miranda Filho, 1988).

Em certas condições, é possivel calcular o coeficiente de endogamia para populações panmíticas e finitas. Há bastante semelhanças entre a equação 3 e as fórmulas que fornecem o grau de endogamia numa 
dada geração, e a consequente perda de heterozigose (Falconer \& Mackay, 1996).

Denomina-se de $\Delta F$ o incremento ou endogamia adicional, de forma que:

$$
\Delta F=\frac{1}{2 N e}
$$

Substituindo a equação 4 em 3 obtém-se:

$$
F_{t}=\Delta F+(1-\Delta F) F_{t-1}
$$

que pode ser rearranjado, tornando mais claro o significado preciso do incremento $\Delta F$, isto é:

$$
\Delta F=\frac{F_{t}-F_{t-1}}{1-F_{t-1}} .
$$

Pela equação 5 , nota-se que o incremento $\Delta F$ mede a taxa de endogamia na forma de aumento proporcional. De acordo com a equação $6, \circ \Delta F$ representa o incremento no coeficiente de endogamia em uma geração $(t)$, tomado em relação à geração anterior (t-1). Quando o coeficiente de endogamia é expresso em termos de $\Delta F$, as equações 5 e 6 , são válidas para qualquer sistema de acasalamento e não são restritas à população ideal, apesar de que somente na população ideal $\Delta F$ é igual a $\left(1 / 2 N_{e}\right)$ (Falconer \& Mackay, 1996):

Assim , a variância da mudança na freqüência alélica em uma geração, baseada na equação 1 e expressa em termos da taxa de endogamia, torna-se: 


$$
\sigma_{\delta \mathrm{p}}^{2}=\frac{p_{0} q_{0}}{2 N e}=p_{0} q_{0} \Delta F
$$

De modo semelhante, a variância das freqüências alélicas entre as subpopulações, na geração $t$, obtidas pela equação 2 e expressa em termos de coeficiente de endogamia pela equação 7 , torna-se:

$$
\sigma_{\delta \mathrm{p}_{\mathrm{t}}}^{2}=p_{0} q_{0}\left[1-\left(1-\frac{1}{2 N e}\right)^{t}\right]=p_{0} q_{0} F,
$$

portanto, $\Delta F$ expressa a taxa de dispersão e $F$ o coeficiente de endogamia acumulado das $t$ gerações (Falconer \& Mackay, 1996).

As proporções genotípicas podem ser apresentadas de duas maneiras: em subpopulações submetidas a diferentes graus de endogamia e de acordo com a identidade para um loco com 2 alelos, expressas em termos de endogamia, $F$, como apresentado na Tabela 2.

Tabela 2 -Proporções genotípicas de subpopulações em diferentes niveis de endogamia e de acordo com origem. (Falconer \& Mackay, 1996).

\begin{tabular}{|c|c|c|c|c|c|c|c|}
\hline & & & & & independentes & & idênticos \\
\hline AA & $p_{0}^{2}$ & + & $p_{0} q_{0} F$ & ou & $p_{0}^{2}(1-F)$ & + & $p_{0} F$ \\
\hline$A^{\prime}$ & $2 p_{0} q_{0}$ & - & $2 p_{0} q_{0} F$ & ou & $2 p_{\circ} q_{0}(1-F)$ & & \\
\hline$A^{\prime} A^{\prime}$ & $q_{0}^{2}$ & + & $p_{o} q_{0} F$ & ou & $q_{0}^{2}(1-F)$ & + & $q_{0} F$ \\
\hline
\end{tabular}

\begin{tabular}{ccc}
\hline Genótipos & $\begin{array}{c}\text { Freqüências } \\
\text { originais }\end{array}$ & $\begin{array}{c}\text { Alteraçoes } \\
\text { causada pela } \\
\text { endogamia }\end{array}$ \\
& & Origem \\
\hline
\end{tabular}


A freqüência dos homozigotos idênticos, tomando ambos os genótipos homozigotos em conjunto, é, por definição; o coeficiente de endogamia, $F$, e é claro que a divisão entre os dois genótipos é proporcional às freqüências alélicas iniciais. Essas formas de reproduzir as freqüências genotipicas mostram como os heterozigotos são reduzidos em freqüência proporcionalmente a (1-F).

A importância genética da endogamia reside no fato de ela provocar aumento da homozigose. Uma das conseqüências importantes do fenômeno relaciona-se com alelos recessivos raros. Nas populações endógamas estes aparecem em condição homozigota mais frequentemente do que nas populações grandes e panmíticas. E em populações panmíticas a carga genética entra em homozigose, sendo então possivel eliminar esses alelos deletérios contribuindo para o melhoramento das populações e obtenção de linhagens puras. Os melhoristas de plantas e animais têm empregado a endogamia sistemática, nos seus programas, justamente por causa disto. Estes programas têm muito valor aplicado porque produzem homozigotos que, depois de selecionados, perpetuam seu genótipo na descendência (Brewbaker, 1969).

\subsection{Estudos sobre deriva genética}

Os aspectos teóricos dos processos aleatórios, desenvolvidos inicialmente no trabalho de Wright (1931), têm sido verificados experimentalmente tanto em populações naturais, como em populações experimentais. Alguns exemplos da provável ocorrência de modificações genéticas aleatórias foram empregaados para explicar muitos tipos de diferenciação que ocorrem em populações animais e vegetais, especialmente quando elas são pequenas e distantes umas das outras. 
Os estudos realizado por Lamotte (1951), na França, e por Cain e \& Sheppard (1954), na Inglaterra, são exemplos ilustrativo, ligados à deriva genética que foram extensivamente investigados e dizem respeito ao polimorfismo da coloração do caracol terrestre Cepaea nemoralis. Estes caracóis têm uma distribuição geográfica descontínua formando populações limitadas, ou "colônias" em vários habitat, como bosques, campos arbustivos, campos sub-arbustivos e em campos abertos, mais ou menos separados por regiões desfavoráveis ao seu desenvolvimento. Em praticamente todas as populações os caracóis têm uma coloração bem definida e um padrão típico de variação no aspecto. Os caracóis apresentam conchas marrons, cor-de-rosa ou amarelas. Alguns possuem uma única cor enquanto outros apresentam de uma a cinco faixas ou bandas escuras longitudinais. As diferenças na pigmentação são controladas por uma série de alelos, sendo o amarelo (y) recessivo em relação ao rosa $(Y)$, e o marrom $\left(Y^{b}\right)$ dominante em relação aos outros dois alelos. A coloração uniforme das conchas (B) é dominante em relação a todas as formas de bandas (b), enquanto que outros alelos controlam o número e a posição das bandas. Os dois locos $Y$ e B são fortemente ligados, constituindo um supergene quando herdados. $O$ polimorfismo quanto à cor e as bandas parece ter sido uma constante na história evolutiva desses caracóis. uma vez que, os diferentes tipos de bandas foram encontrados em caracóis fósseis do Pleistoceno na Inglaterra e na França em freqüências não muito diferentes das verificadas atualmente nas populações das mesmas regiões.

Lamotte (1951), verificou que as freqüências médias dos tipos de bandas e das colorações dos caracóis variam grandemente entre as diferentes regiōes. No entanto, também ocorre uma considerável variação entre as colônias dentro de cada região. A freqüência média de caracóis sem faixas é $29 \%$, e nas colônias individuais, variam entre 0 (zero) e 1 de freqüência , sendo algumas inteiramente sem faixas, e poucas inteiramente com faixas. As colônias variam no número de indivíduos que contêm, e 291 colônias foram classificadas em 3 grupos, de acordo com o tamanho de sua população. A 
variação da freqüência de caracóis sem faixas foi então comparada nos três grupos. A variação entre as colônias, a qual mede 0 grau de diferenciação, foi maior entre as pequenas colônias do que entre as maiores. A variância da freqüência de caracóis sem faixa foi de 0,067 entre colônias de 500 a 1000 individuos; 0,048 entre colônias de 1000 a 3000 indivíduos, e 0,037 entre colônias de 3000 a 10000 indivíduos. Esta diferença entre as populações, fica evidentemente intensificada pelo pequeno fluxo gênico que existe, já que os caracóis têm pouca motilidade (migração). Como a Cepaea se desenvolve em muitos habitats, é possivel que a variação entre as colônias seja uma conseqüência da ação de diferentes forças seletivas que agiram de acordo com a natureza especifica de cada habitat. As diferenças, por outro lado, poderiam ser explicadas por flutuações aleaórias das freqüências alélicas. Neste caso, as diferenças deveriam ser tanto maiores quanto menores as colônias, considerando-se, que a ação da seleção natural não depende do tamanho da população. Resumidamente, concluiu-se que as populações pequenas apresentavam uma maior variabilidade, e uma maior freqüência de homoalelismo, em relação às populações maiores. Além disso, as freqüências das colônias pequenas e vizinhas não tinham muita relação entre si, sendo porém mais relacionadas as das populações grandes e próximas. Estas observações mostraram definitivamente que 0 grau de diferenciação depende do tamanho da população e Lamotte (1951), apesar de reconhecer a existência de forças seletivas impostas pelo ambiente atribuiu à deriva genética o aumento na diversidade entre as populações pequenas. Isso fica de acordo com o que foi exposto, pois como verificou-se que a $\sigma_{\delta q}^{2}$ é inversalmente proporcional ao tamanho populacional.

Cain \& Shéppard (1954), por outro lado, oferecem uma interpretação diferente, sustentada por um estudo igualmente completo de. colônias na Inglaterra. Eles mostram que a predação feita pelos pássaros fazem grande seleção em favor de conchas, com um padrão de cor que se confunde com a coloração do habitat. Embora o polimorfismo seja mantido por 
seleção de natureza desconhecida em favor dos heterozigotos, a freqüência dos diferentes tipos em qualquer colônia é determinada pela seleção relativa à natureza do habitat. Nas áreas ocupadas por pequenas colônias, eles argumentam que há menor variação no habitat do que em áreas ocupadas por colônias grandes. Portanto, a variação de habitat entre pequenas colônias é maior do que entre as grandes. Consideram isso causa de maior diferenciação entre as pequenas colônias do que entre as grandes, e a seleção conduz a freqüência das formas sem faixas a um valor apropriado para o habitat médio da colônia.

Segundo Mettler \& Gregg (1973) foram encontradas evidências a favor da interpretação de Cain \& Sheppard (1954). Além de verificarem uma variação típica entre colônias, encontraram uma conexão entre composição genotípica das populações e tipo de habitats. Assim, notaram que os tipos mais freqüentes eram aqueles que menos realçavam em cada habitat. Dessa forma, os caracóis amarelos eram encontrados abundantemente nos terrenos onde predominava a cor verde, como em campos com grama e arbustos. Os caracois marrons, por sua vez, eram mais comuns nos bosques onde dominava uma cor escura de folhas mortas e de terreno limpo. Os caracóis com bandas eram encontrados mais em habitats onde havia contrastes e diversidade de cores na vegetação, enquanto que os sem bandas ocorreram em regiões onde o ambiente era de tonalidade uniformes. Essas correlações são evidências de que a seleção natural ocorre em função do ambiente. Embora a seleção visual aparentemente atue como determinadora da freqüência relativa das várias formas em cada habitat, as forças responsáveis pela natureza balanceada deste polimorfismo não foram determinadas. Também não foi mostrada uma superioridade dos heterozigotos, embora haja razões para crer que a heterose esteja associada com condições fisiológicas que são simultaneamente controladas por estes genes que controlam a coloração e bandas. Ainda que existam outros caminhos pelos quais o polimorfismo balanceado possa ser mantido, como o fluxo gênico entre populações adaptadas a diversos habitats, 
nenhum parece fornecer explicações suficientes neste caso. Finalmente, é preciso reconhecer que as correlações não são perfeitas, mas é razoável admitir que a deriva genética, possivelmente devida ao principio dos fundadores, exerceu sua ação produzindo alguma diversidade nas colônias menores.

Um grupo de experimentos comparáveis foram realizados por Kerr \& Wright (1954a) e Wright \& Kerr (1954), com populações de Drosophila melanogaster, onde a migração e a mutação eram despreziveis e a seleção não pode ser controlada. Kerr \& Wright (1954a) estudaram separadamente 96 pequenas populações de 8 indivíduos tomados ao acaso (4 machos e 4 fêmeas), sendo que cada subpopulação gerava a subpopulação da geração seguinte. Inicialmente cada subpopulação possuia um gene para cerdas "forked" (bifurcadas ou recurvadas) e o seu alelo selvagem (normal), cada um com a freqüência de 0,5 . Após 16 gerações de cruzamentos ao acaso, os alelos forked e o selvagem estavam segregando em somente 26 das subpopulações, enquanto quie o alelo forked havia se fixado em 29 das subpopulações e 0 alelo selvagem havia se fixado nas outras 41 subpopulações. A taxa de fixação atingiu um equilibrio aproximado por volta da quarta geração, com um valor de $8,9 \%$ por geração. Isto indica que a deriva genética tende a produzir homozigose e que é o acaso que determina qual alelo é fixado numa determinada população. Contudo, os resultados foram aparentemente influenciados pela seleção, pois os alelos selvagens foram um pouco favorecidos. Os efeitos da seleção mostraram-se mais evidentes em oútras populações onde se estudou o gene bar (Wright \& Kerr, 1954) em 108 subpopulações de tamanho 8 (4 machos e 4 fêmeas) estudadas durante 10 gerações. Partindo de uma freqüência alélica de 0,5 , a distribuição da freqüência alélica atingiu uma estabilidade aparente na quarta geração com uma taxa de fixação de $22 \%$ para o tipo selvagem e $0,7 \%$ para o tipo bar por geração. Após dez gerações em 95 das subpopulações o alelo selvagem 
estava fixado e 3 fixados para o tipo bar, e em , 10 subpopulações esses alelos não haviam fixados, ou estavam segregando.

O importante, no caso, é que a fixação ocorreu na maioria das subpopulações e que, em alguns casos, o alelo perdido foi o selvagem que, provavelmente, era superior. Tal resultado, isto é, fixação aleatória de características de baixo valor adaptativo não é esperado em populações de tamanho efetivo alto nas quais a seleção predomina.

De maneira similar, Kerr \& Wright (1954b) estudaram a deriva dos genes aristapedia e spineless em Drosophila melanogaster, em 113 subpopulações de mesmo tamanho $(N=8)$ e igual número de gerações $(t=10)$ que 0 experimento anterior. Nesse terceiro experimento, estudaram-se populações pequenas com alelos heteróticos, isto é, os genótipos heterozigotos mostraram-se superiores aos homozigóticos, em testes nos quais se estudaram os componentes de adaptação. Nestes, verificou-se uma dispersão da freqüência alélica entre as populações, a variância da freqüência do alelo spineless aumentou de 0,01707 para 0,02693 entre as gerações 1 e 10, com uma rápida estabilização na distribuição da freqüência alélica; no final de dez gerações, oito subpopulaçōes atingiram a fixação para este gene. $O$ gene aristapedia atingiu a máxima freqüência de $87,5 \%$, com média de $38,8 \%$. Kerr \& Wright (1954b) também mostraram que a oportunidade para ocorrer fixação durante a deriva genética é drasticamente reduzida guando a seleção favorece decididamente os heterozigotos.

Buri (1956) procedeu a um estudo de deriva na freqüência do gene Brown (bw) em Drosophila melanogaster, partindo de uma população com freqüência alélica igual a 0,5 e subdividida em 32 subpopulações de tamanho $\mathrm{N}=16$ (8 machos e 8 fêmeas). Após 19 gerações de cruzamento ao acaso em duas séries de experimentos (I e II), o grau de heterozigose decresceu de $100 \%$ para $18,35 \%$ e $21,0 \%$ nas séries I e II, respectivamente. A distribuição das freqüências alélicas entre subpopulações estabilizou nas gerações 11 e 17 , respectivamente. A variância da freqüência alélica entre as gerações 1 e 19 
aumentou gradativamente de 0,006 a 0,170 na série I e de 0,009 a 0,144 na série II. As alterações correspondentes na variância teórica esperada foram de 0,014 a 0,166 na série I e de 0,011 a 0,143 na série II, estando muito próximas dos valores observados.

Estes experimentos demonstraram que a variação aleatória da freqüência alélica de fato ocorre em populações pequenas e isoladas, produzindo os resultados esperados teoricamante.

A maioria dos autores, segundo Mettler \& Gregg (1973), concorda com as teorias de Wright em que a deriva no seu aspecto clássico, isto é, flutuações aleatórias das freqüências alélicas em populações isoladas que permanecem pequenas, tem provavelmente importância. Isso, porque tais populações serão geralmente mal adaptadas pois muitos locos ficarão homozigóticos, estando alguns representados por alelos seletivamente inferiores que oscilaram em direção à fixação. Essa perda de adaptabilidade, associada com a homozigose, é discutida sob o ponto de vista da perda de vigor pela endogamia. Essa perda é um fato que comumente acompanha a autofertilização ou outros tipos de endogamia, em subpopulações normalmente alógamas de plantas e em animais. Este conceito se aplica aqui, pois a importância da endogamia sempre aumenta, à medida que diminui o tamanho da população, independente do sistema de acasalamento, de fato, a deriva pode ser considerada como um processo endogâmico e pode ser descrita em termos de coeficiente de endogamia. A deterioração torna-se mais evidente e a variação torna-se mínima quanto maior o número de alelos fixados com a endogamia continuada. A seleção, por isso, passa a ter pouca reserva para promover um aumento no nivel de adaptação e o resultado, no final, é a degeneração e extinção.

É evidente que a extinção é o mais provável destino de uma. população reduzida a um tamanho crítico, ou de uma população nova originada de poucos individuos que migraram para fora do habitat normal da espécie. Contudo, é exagero dizer que isso é inevitável. Algumas subpopulações 
altamente endogâmicas mostraram-se persistentes durante várias gerações. Do mesmo modo, uma população pequena e isolada pode tornar-se especificamente adaptada a um habitat característico e manter-se com sucesso nesse habitat por longo período. Conhecem-se exemplos de algumas populações em que isso ocorreu. Todavia, tais populações sempre confrontamse com a possibilidade de alterações do meio ambiente às quais elas podem não se ajustar; por isso elas também estão propensas a extinguir-se. Pode acontecer porém que uma mudança ambiental resulte na extinção do nicho ecológico da pequena colônia, o que favorecerá a expansão da população. Em circunstâncias como essa existe um grande potencial para avanços evolucionários. Um pequeno isolado pode ter um terceiro destino, além da extinção ou da expansão, que é a fusão com outras populações. Este, porém, não é de muito interesse, pois qualquer diferenciação que se estabeleceu durante o isolamento é logo perdida quando é restabelecida a livre troca de genes (Metter \& Gregg, 1973).

Deve-se também considerar que a endogamia por si só, nem sempre é detrimental para uma espécie. Há muitas espécies de plantas bem adaptadas que adotaram a autofertilização como seu sistema normal de acasalamentos. Além disso, a endogamia não conduz necessariamente à homozigose em todos os locos. O caminho para uma fixação completa é um processo vagaroso, mesmo quando a seleção não está envolvida e mesmo que a endogamia seja extrema. Que a seleção deve estar envolvida é certo, e esta, favorecendo a condição heterozigótica, diminuirá grandemente os efeitos da deriva genética.

Há uma grande quantidade de evidências que suportam o conceito de especiação geográfica. Muitos afirmam que populações isoladas originadas de poucos imigrantes, são particurlarmente sujeitas a uma drástica reconstrução genética e a um rápido avanço evolucionário. A oportunidade para ocorrer a deriva nesta situação só existe no início do processo, isto é, dentro do grupo "fundador" que é geneticamente 
restrito. Desde que a maioria das colônias sobreviventes tende a crescer em tamanho, a deriva passa a ser um evento que acontece de modo brusco e só uma vez. Ela ocorre devido à natureza aleatória dos zigotos que constituem a pequena amostra de variação genética contida nos fundadores. $O$ importante a ser realçado é que as várias colônias fundadoras (ou populações reduzidas) possuirão bases genéticas limitadas e distintas ( por obra ao acaso). Quando um estoque fundador como esse se estabelece, a seleção acumulará os genótipos mais adaptados entre aqueles que inicialmente se formaram. Assim, o curso da evolução, sempre dirigido pela seleção, dependerá grandemente dos recursos genéticos presentes no início da existência das colônias fundadoras; diferentes cursos evolutivos resultarão, dependendo das bases genéticas iniciais.

Dobzhansky e Pavlovsky (1957), demonstraram a interação que há entre seleção e este tipo "fundador" de deriva, em populações experimentais de Drosophila pseudoobscura. Eles mostraram que existe uma diversidade maior nos resultados da seleção quanto menor for a população inicial. Partindo de um estoque base, de individuos de uma geração $F_{2}$ obtida da hibridação entre moscas homozigotas originárias do Texas e da califórnia. As moscas do Texas eram homozigotas para um arranjo gênico do terceiro cromossomo denominado $A R$, enquanto que as da Califórnia eram homozigotas para uma sequência diferente, simbolozada por PP. Deste modo, os cromossomos AR e PP eram esperados com igual freqüência no estoque básico. Os autores criaram 20 populações experimentais de indivíduos tomados ao acaso dos estoques básicos. Dessas populações dez foram iniciadas com 20 fundadoras e as 10 populações restantes iniciadas com 4000 moscas cada uma. Depois de algumas gerações, as populações pequenas cresceram, atingindo um tamanho comparável ao das populações grandes, daí em diante todas elas foram colocadas sob um mesmo tipo de seleção. As 20 populações foram analisadas aos 3 meses e aos 17 meses (aproximadamente 21 gerações de seleção). A freqüência dos arranjos PP durante a segunda 
análise nas populações fundadas por poucos indivíduos variou de 16 a 47\%, e nas populações inicialmente grandes a freqüência variou menos, de 20 a $35 \%$. Sabia-se que as freqüências dos arranjos PP e AR em qualquer população eram dirigidas por fortes forças seletivas que favoreciam a condição heterozigotica PPIAR. Contudo, a maior heterogeneidade observada entre as diversas populações pequenas em relação as grandes, é muito significativa. De fato, ela pode ser considerada uma prova de gue os resultados da seleção nas populações inicialmente pequenas foram condicionadas, em parte, pela deriva genética, a qual obviamente já estava presente nas gerações fundadoras. Estes resultados surportam a teoria de que a deriva e a seleção devem interagir na promoção de modificações evolucionárias, mesmo que a redução do tamanho de uma população seja apenas uma condição temporária.

Esses autores serviram-se dos fatos citados acima para explicar a divergência existente entre certas populações na natureza, as quais foram submetidas a uma redução no tamanho (ou afunilamento) como é o caso daquelas fundadas por imigrantes em pequenas ilhas. Um outro exemplo foi dado por Ford (1953), observando a variação interpopulacional em borboletas marrons, Maniola jurtina. Os indivíduos dessa espécie têm um número variável de pequenas manchas ( 0 a 5 ) na parte inferior das asas posteriores; as populações podem ser caracterizadas de acordo com a distribuição das freqüências dessas manchas. Verificou-se gue as distribuições das manchas nas populações das ilhas maiores eram semelhantes entre si. As distribuições nas populações de certas ilhas peguenas, porém, eram bastantes diferentes uma das outras e também diferentes das observadas nas ilhas maiores. A distribuição característica das manchas de cada população nas várias ilhas permaneceu constante de ano para ano. Houve apenas algumas exceções. A similaridade das populações das ilhas grandes certamente não pode ser explicada como devido ao fluxo gênico, pois as distâncias entre as ilhas são uma barreira segura contra a migração. Além disso, as ilhas menores, que possuem populações tão distintas, situam-se entre as ilhas maiores. 
Dobzhansky e Pavlovsky (1957) sugeriram que as populações das ilhas pequenas, embora sejam compostas atualmente por grande número de indivíduos, originaram-se de um pequeno número de imigrantes. Sugeriram ainda que cada população das ilhas pequenas foi iniciada com uma diferente base genética, a partir da qual se desenvolveram conjuntos gênicos relativamente estáveis, mas diferentes. Ford (1953) não concorda com isso, e sugeriu que cada população está ajustada às condições de cada ilha; as populações de borboletas das ilhas maiores são semelhantes porque elas foram selecionadas para a média das várias condições; cada população de uma ilha pequena ao contrário é selecionada para habitats diferentes mas bastante uniformes. Ele afirma que as fortes pressões de seleção na natureza (e expressas em cruzamentos artificiais) são tudo o que é necessário para explicar a variação que ocorre em Maniola jurtina.

Reconhecendo que, ao longo do processo de seleção recorrente, os efeitos da depressão por endogamia devidos à deriva genética ficam confundidos com os efeitos do aumento na freqüência de alelos favoráveis via seleção, Smith (1979a,b, 1983) propôs um modelo para obter a separação destas informações. Entre vários parâmetros o modelo estima à contribuição dos locos em homozigose ou dos efeitos aditivos para o ciclo 0 de seleção recorrente das populações (AOI), à contribuiçāo dos locos em heterozigose ou dos efeitos de dominância para o ciclo 0 das populações (DOI) e as funções quadráticas das alterações nos locos em heterozigose das populações que correspondem ao efeito da deriva genética nas populações, pelo uso de tamanhos efetivos populacionais reduzidos $(\mathrm{Ne}<25)$ (DQI).

A partir de então, vários trabalhos foram realizados visando quantificar os efeitos das alterações nas freqüências alélicas decorrentes da seleção e da deriva genética em populações de miho submetidas a diferentes . métodos de seleção recorrente. A ocorrência de efeitos significativos da deriva genética, dada pelo parâmetro DQI, afetando o desempenho das populações 
per se e obtidas via seleção recorrente intrapopulacional e via seleção recorrente recíproca, atuando em sentido contrário ao do progresso com a seleção. Deve-se salientar que, de maneira geral, foi observada contribuição significativa dos efeitos aditivos e de dominância nas populações originais (AOI e DOI, respectivamente). A magnitude destes efeitos tem sido bastante variável nos diferentes estudos, nâo existindo uma tendência de predominância de algum tipo, aditivo ou dominante (Eyherabide \& Hallauer, 1991; Helms et al., 1989; Keeratinijakal \& Lamkey 1993; Landi \& Frascaroli, 1993; OyervidesGarcia \& Hallauer, 1986; Rezende ,1997; Smith, 1979; Smith, 1983; Stoj š in \& Kannenberg, 1994; Tragesser et al.,1989). Evidenciando a importância da deriva genética como um fator limitante ao progresso obtido com a seleção nos programas de melhoramente com a cultura do milho.

Paterniani (1995), estudou duas populações-base denominadas de $A$ e $B$, sintetizadas de duas populações $F_{2}$, de onde foram retiradas 29 subpopulações que foram submetidas a duas gerações de endogamia com populações reduzidas $(\mathrm{N}=5)$. Através de avaliação visual, foram determinadas as freqüências genotípicas de cada planta-mãe constituinte das amostras, associadas à freqüência gênica para o caráter cor do endosperma ( $Y$-amarela e y-branca) de cada subpopulação. Na primeira geração, as freqüências alélicas mantiveram-se próximas ao valor esperado no processo dispersivo [esperança matemática, $E(p)=p_{0}=0,5$ ]; após duas gerações, houve aumento significativo na freqüência do alelo $Y$, principalmente na população $B$, para 0 qual foi obtido valor de seleção de 0,97 , indicando uma vantagem seletiva para o gene $Y$ em detrimento ao alelo $Y$, que determina coloração branca do endosperma. . Ressalta-se que a redução do tamanho efetivo populacional $(\mathrm{Ne}=5)$ levou à fixação do alelo $\mathrm{Y}$ em duas de 29 populações $(6,9 \%)$ obtidas da população-base B. Analisando também as oscilações de médias dos caracteres quantitativos, a autora concluiu que de maneira geral, a população B apresentou maior grau de heterozigosidade, uma vez que foram obtidos 
maiores valores de depressão por endogamia, de efeito de heterozigotos e maiores diferenças entre médias de subpopulações e controle, para a maioria dos caracteres estudados. Por outro lado, a população A apresentou subpopulações com maior peso de grãos, maiores valores de $\mu+a$ (contribuição dos homozigotos) e menores valores de endogamia, sendo potencialmente útil para extração de linhagens homozigoticas.

Uma abordagem diferente foi feita por Corrales Blandón (1996), no estudo da deriva genética com a cultura do milho. O objetivo foi de explorar, mediante o uso de estimativas de parâmetros genéticos, a possibilidade de usar a amostragem como técnica auxiliar em programas de melhoramento para obter linhagens endogamas, liberar variabilidade genética e promover 0 acúmulo diferenciado de alelos favoráveis entre subpopulações. $O$ autor trabalhou com uma população $F_{2}$, de onde retirou 30 subpopulações de tamanho $\mathrm{N}=5$, que foram retiradas aleatoriamente e reproduzidas isoladamente durante duas gerações. Essas subpopulações foram avaliadas com base no desempenho "per se" e em cruzamentos com seis testadores sendo que familias de meios irmãos também foram obtidas de cinco subpopulações e da população parental. Das avaliações, foram obtidas.estimativas de médias "per se", depressão endogamica, capacidade geral de combinação e da variância genética aditiva. Observou-se que para todos os caracteres avaliados a deriva genética causada pela amostragem provocou o surgimento de algumas subpopulações com médias, e estimativas de capacidade geral de combinação ou variância genética aditiva, similares ou superiores à população parental. Houve ainda o aumento da proporção de homozigotos, entre as subpopulações, a qual foi refletida na depressão por endogamia. Concluiu que a deriva genética provocada pela amostragem, mostrou-se um procedimento promissor para gerar subpopulações de alto valor genético úteis aos propósitos dos melhoristas.

Rezende (1997) estudou os efeitos da seleção e da deriva genética sobre a heterose e a depressão por endogamia em duas populações 
de milho e suas respectivas variedades sintéticas, que foram obtidas após um ciclo de seleção recorrente recíproca com utilização de elevadas intensidades de seleção que foram intercruzadas em sistema dialélico, autofecundadas e multiplicadas. Paralelamente, procurou verificar os efeitos da seleção e da deriva genética sobre a variabilidade genética dos materiais, pela avaliação de 169 progênies de irmãos germanos interpopulacionais do cruzamento entre as populações e sintéticos. Concluiu que a magnitude das alterações observadas na heterose do híbrido interpopulacional e na depressão por endogamia das populações foi função de modificações nas freqüências de alelos de efeito dominante nas populações "per se" e no híbrido interpopulacional, e principalmente, função dos efeitos da redução na heterozigose por deriva genética, atuando significativamente no sentido de reduzir a média da maioria das características, em ambas as populações. A deriva genética foi significativa e limitou o melhoramento das populações per se. Além disso, o processo de melhoramento do híbrido interpopulacional se deu sem que houvesse perda da distribuição normal e presença de assimetrias na distribuição dos dados indicando, portanto, que o efeito conjunto da seleção e da deriva genética não afetou significativamente os padrões de variação das progênies interpopulacionais, garantindo a integridade da variabilidade genética necessária para a realização de futuros ciclos de seleção.

$\mathrm{Na}$ discussão de todos esses exemplos a deriva e a seleção são vistas como alternativas exclusivas, uma ou outra são apontadas como a única responsável pelas mudanças genéticas observadas. Deve-se ressaltar aqui que a importância da deriva não deve ser exagerada só porque um caráter parece ser pouco relacionado com a adaptação. Por outro lado, ela também não deve ser considerada absurda se os genes envolvidos têm alguma influência sobre a adaptação. $O$ papel da deriva é demonstrado matematicamante, e a seleção uma certeza definida pela biologia. Elas desempenham papéis complementares na evolução, os quais são demonstráveis mas que raramente são separáveis na prática . 
Concluindo, resta dizer que os modelos matemáticos para a deriva genética foram bem evidenciados pela experimentação. A discussão em torno da importância ou não da deriva genética na evolução parece que não terminará tão cedo. Certamente não findará enquanto não forem feitas mais pesquisas e enquanto se continuar a discussão em termos especulativos (Futuyma, 1992). 


\section{MATERIAL E MÉTODOS}

\subsection{Material genético}

O trabalho foi realizado a partir de duas populações de milho denominadas BR-105 e BR-106, obtidas no Centro Nacional de Pesquisa de Milho e Sorgo (EMBRAPA). Estas populações possuem origem e estruturas genéticas diferentes (Naspolini Filho et al., 1981). A população BR-105 é originária da Tailândia enquanto a BR-106 se origina de materiais do Brasil e do México. Ambas apresentam ciclo vegetativo e porte intermediários, sendo que a BR-105 possui grãos semi-duros de coloração alaranjada e a BR-106 possui grãos dentados de coloração amarela. As populações são muito divergentes geneticamente, haja vista a magnitude da heterose de seu cruzamento (Souza Jr. et al ., 1993).e sua distância genética (Lanza et al., 1997)

Para o presente estudo foram utilizadas 10 subpopulações obtidas de duas gerações sucessivas de amostragem de tamanho efetivo reduzido $\left(N_{e}=5\right)$, das populações BR-105 e BR-106 (gerações de deriva genética) constituindo 20 subpopulações para cada população.

Para a obtenção das subpopulações de tamanho efetivo reduzido foram plantadas lotes separados de sementes das populações BR-105 e BR106. Por ocasião do florescimento, foram autofecundadas várias plantas, 
aleatoriamente. Estas plantas foram colhidas separadamente e a mistura de sementes de 5 plantas tomadas ao acaso, constituiram uma subpopulação.Foram então, estabelecidas 10 subpopulações da população BR-105 e 10 subpopulações da população BR-106. Como cada planta tem tamanho efetivo $(\mathrm{Ne})$ igual a 1,0, os tamanhos efetivos de cada subpopulação é $\mathrm{Ne}=5,0$.

De cada subpopulação, foram plantadas 50 fileiras de $1 \mathrm{~m} \mathrm{(5}$ plantas $/ \mathrm{m}$ ), sendo que cada fileira continha uma planta de cada uma das 5 plantas autofecundadas e individualizadas. As plantas deste lote foram polinizadas, entre si, com o objetivo de serem recombinadas. $O$ lote das 50 fileiras de cada subpopulação foram colhidos e debulhados conjuntamente, constituindo a primeira geração $\left(G_{1}\right)$ de amostragem. Quando debulhadas, apenas uma porção das sementes da base das espigas foram separadas e armazenadas para avaliação e formação da segunda geração de amostragem $\left(G_{2}\right)$. Para obter a segunda geração, foram plantados uma fileira de $5 \mathrm{~m}$ de comprimento (25 plantas) de cada subpopulação da primeira geração, que foram autofecundadas e colhidas separadamente. Novamente, as sementes de 5 plantas de cada subpopulação foram misturadas para compor a nova geração. Essas subpopulações foram então, recombinadas, seguindo o esquema utilizado na geração anterior. Cada subpopulação na primeira geração deu origem a correspondente subpopulação na segunda geração. Foram, portanto, obtidas 10 subpopulaçōes em $\mathrm{G}_{1}$ e 10 subpopulação em $\mathrm{G}_{2}$ de deriva genétca para cada população, tendo um total de 40 subpopulações.

Os tratamentos foram constituidos das populações originais BR-105 e BR-106, das 20 subpopulações da primeira geração, das 20 subpopulações da segunda geração, e de 7 híbridos comerciais, totalizando 49 entradas. Os hibridos comerciais utilizados foram Agroceres 5011, Agroceres 9012, Agroceres 9014, Agroceres 672, Zeneca 8392, Zeneca 8452 e Cargill 855. 


\subsection{Procedimentos experimentais}

Os 49 tratamentos foram avaliados em Látice $7 \times 7$ com 8 repetições em 5 ambientes. Os cinco experimentos foram instalados em locais e épocas diferentes de plantio. Em Piracicaba-SP, foram instalados dois experimentos em 28/11/96 e 08/01/97 na Estação Experimental Caterpillar e um experimento em 14/01/97 na Estação Experimental da ESALQ , ambos do Departamento de Genética da ESALQ/USP. Em Londrina-PR foram instalados dois experimentos: plantados em 19/11/96 e 04/12/96 no Centro Nacional de Pesquisa de Soja (CNPSoja - EMBRAPA).

A parcela experimental em Piracicaba-SP constou de duas fileiras de $4 \mathrm{~m}$ de comprimento, espaçadas de $0,80 \mathrm{~m}$ entre fileiras e $0,20 \mathrm{~m}$ entre plantas dentro da fileira, com um total de 40 plantas por fileira após o desbaste, que corresponde a 62.500 plantas/ha. Em Londrina -PR, a parcela experimental constou de duas fileiras de $4 \mathrm{~m}$ de comprimento, espaçadas de 0,90 m entre fileiras e 0,20 m entre plantas dentro da fileira, com um total de 40 plantas por fileira após o desbaste, o que corresponde a uma população de 55.555 plantas/ha.

Foram avaliados os seguintes caracteres:

P - Produção por hectare (ton/ha): as parcelas foram colhidas e debulhadas, sendo os grãos pesados. Foram realizadas correções no caráter $\mathrm{P}$ para 0 estande ideal (40 plantas) através do método da covariância (Vencovsky \& Barriga, 1992) e em seguida, foram transformados em toneladas por hectare de acordo com cada plantio realizado;

AP - Altura da planta (cm): avaliada em cinco plantas competitivas escolhidas ao acaso em cada fileira da parcela, constituindo 10 plantas avaliadas por parcela. A altura de planta foi medida da superficie do solo até a inserção da última folha; 
AE - Altura da espiga (cm): avaliada com os mesmos critérios adotados para AP; a altura de espiga foi medida da superficie do solo até a inserção basal da primeira espiga;

PRO - prolificidade (espiga/planta): obtido pela relação entre número total de espigas da parcela e estande final;

r=AE/AP - relação entre altura da espiga e altura de planta. Indica a posição relativa da espiga na planta.

Foram, também, obtidos dados de plantas individuais dos experimentos para se obter estimativas de variâncias fenotipicas e as distribuições de freqüencias das populações BR-105 e BR-106 e de suas respectivas subpopulações. Os caracteres peso de grãos por planta (PG em g/planta), altura da planta (AP em cm/planta) e altura da espiga (AE em $\mathrm{cm} /$ planta) foram avaliados em quatro repetições dos três experimentos instalados em Piracicaba, SP., em 10 plantas competitivas por parcela.

Em todos os experimentos o caráter peso de grãos não foi ajustado para o teor de umidade, uma vez que antes da pesagem, as espigas de todas as parcelas foram deixadas em local seco por cerca de uma semana para uniformizar o teor de umidade. 


\subsection{Análises estatísticas e genéticas}

\subsubsection{Análises de variâncias}

Os dados experimentais de cada ambiente foram submetidos a análises de variâncias segundo 0 delineamento experimental Blocos Casualizados Completos uma vez que não houve eficiência na análise no delineamento em Látice.

Análise individual:

$Y_{i j}=m+b_{j}+t_{i}+e_{i j}$, onde

$Y_{i j}$ é a observação relativa ao tratamento $i$, no bloco $j$;

m é a média geral;

$b_{j}$ é o efeito do bloco $j(j=1,2, \ldots . ., 8)$;

$t_{i}$ é o efeito do tratamento $i(i=1,23, \ldots, 49)$;

$e_{i j}$ é o erro experimental associado à observação $Y_{i j}$.

A seguir foram realizadas as análises conjuntas envolvendo os 5 ambientes. 0 modelo matemático utilizado foi:

$Y_{i j m}=m+t_{i}+b_{j(m)}+I_{m}+(t)_{i m}+e_{i j m}$, onde

$\mathrm{Y}_{\mathrm{ijm}}$ é a observação relativa ao tratamento $\mathrm{i}$, do bloco $\mathrm{j}$ dentro do local $\mathrm{m}$; m é a média geral;

$I_{m}$ é o efeito do local $m(m=1,2,3,4,5)$;

$b_{j(m)}$ é o efeito do bloco $j(j=1,2, \ldots . ., 8)$ dentro do local $m$;

$t_{i}$ é o efeito do tratamento $i(i=1,23, \ldots ., 49)$; 
$(t)_{\text {im }}$ é o efeito da interação do tratamento i com o local m; $e_{i j m}$ é o erro experimental associado à observação $Y_{i j m}$.

Nesses modelos todos os efeitos, exceto a média experimental foram considerados aleatórios.

A seguir a soma de quadrados tratamentos foi desdobrada em subpopulações da população BR-105 e BR-106 e outros. As somas de quadrados de cada população foram novamente desdobradas em primeira geração $\left(G_{1}\right)$, segunda geração $\left(G_{2}\right), G_{1}$ vs $G_{2}$ e população vs $G_{1}$ e $G_{2}$, como mostra a Tabela 3.

Tabela 3. Esquema da análise de variância conjunta com os respectivos desdobramentos e teste $F$.

\begin{tabular}{lrcc}
\hline \multicolumn{1}{c}{$F$. V. } & GL & QM & $F$ \\
\hline Locais (L) & 4 & $Q_{1}$ & $Q_{1} / Q_{13}$ \\
Blocos (Locais) & 35 & $Q_{2}$ & $Q_{2} / Q_{14}$ \\
Tratamentos $(T)$ & 48 & $Q_{3}$ & $Q_{3} / Q_{13}$ \\
BR-105 - $G_{1}$ & 9 & $Q_{4}$ & $Q_{4} / Q_{13}$ \\
BR-105 - $G_{2}$ & 9 & $Q_{5}$ & $Q_{5} / Q_{13}$ \\
BR-105 vs $G_{1}$ e $G_{2}$ & 1 & $Q_{6}$ & $Q_{6} / Q_{13}$ \\
BR-105 $G_{1}$ vs BR-105 $G_{2}$ & 1 & $Q_{7}$ & $Q_{7} / Q_{13}$ \\
BR-106 - geração I $\left(G_{1}\right)$ & 9 & $Q_{8}$ & $Q_{8} / Q_{13}$ \\
BR-106 - geração II $\left(G_{2}\right)$ & 9 & $Q_{9}$ & $Q_{9} / Q_{13}$ \\
BR-106 vs $G_{1}$ e $G_{2}$ & 1 & $Q_{10}$ & $Q_{1} / 0 Q_{13}$ \\
BR-106 $G_{1}$ vs BR-106 $G_{2}$ & 1 & $Q_{11}$ & $Q_{11} / Q_{13}$ \\
Outros & 8 & $Q_{12}$ & $Q_{12} / Q_{13}$ \\
Tratamantos X locais & 192 & $Q_{13}$ & $Q_{13} / Q_{14}$ \\
Erro médio & 1680 & $Q_{14}$ & \\
\hline
\end{tabular}

Após a análise estatística obtiveram-se as médias de cada tratamento ( geraçãos $G_{1}$ e $G_{2}$ e da população de origem) para cada caráter Foram comparadas, separadamente, as médias entre as subpopulações na primeira geração e da segunda geração, de cada população de origem, usando 
o teste de Tukey, calculando a diferença mínima significativa $(\Delta)$, conforme Gomes (1990);

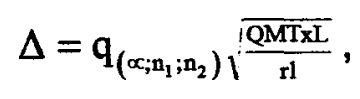

em que:

$q_{\left(\alpha ; n_{1} ; n_{2}\right)}=$ amplitude total estudantizada ao nivel $\alpha(5 \%)$ de significância,

$n_{1}=$ número total de tratamentos a serem comparados,

$\boldsymbol{n}_{2}=$ número de graus de liberdade da interação trat. $X$ local.

QMTXL = quadrado médio da interação trat. $X$ local,

$r=$ número de observaçōes a partir das quais a média foi obtida.

$\mathrm{I}=$ número de locais.

\subsubsection{Avaliação da deriva genética}

Considerando uma populaçāo em equilibrio de Hardy-Weinberg na ausência de seleção, migração e mutação, as médias da população original $\left(\mu_{0}\right)$ de uma amostra retirada aleatóriamente dessa população $\left(\mu_{1}\right)$ e de outra amostra desta amostragem $\left(\mu_{2}\right)$ são:

$$
\begin{aligned}
& \mu_{0}=\mu+(p-q) a+2 p q d, \\
& \mu_{1}=\mu+\left(p_{1}-q_{1}\right) a+2 p_{1} q_{1} d, \\
& \mu_{2}=\mu+\left(p_{2}-q_{2}\right) a+2 p_{2} q_{2} d
\end{aligned}
$$

onde $p$ e q são as freqüências dos alelos $B$ e $b$, respectivamente, qualquer na população e $p_{1}$ e $q_{1}$ são as freqüências desses alelos na amostra e $p_{2}$ e $q_{2}$ são 
as freqüências da segunda amostra, $\mu$ é a média populacional, a 0 valor genotípico dos homozigotos e d o valor genotípico do heterozigoto. Sendo $\mathrm{p}_{1}=\mathrm{p}+\delta_{\mathrm{p}}$ e $\mathrm{q}_{1}=\mathrm{p}-\delta_{\mathrm{p}}$, onde $\mathrm{E}\left(\delta_{\mathrm{p}}\right)=0$ e $\mathrm{E}\left(\delta_{\mathrm{p}}\right)^{2}=\mathrm{pq} / 2 \mathrm{Ne}$ é o efeito da deriva genética, e substituindo-se nas expressōes das médias, obtem-se (Souza Jr., 1995)

$$
\begin{aligned}
& \mu_{1}=\mu_{0}-2 \delta_{p_{1}}^{2} d \quad \text { e, } \\
& \mu_{2}=\mu_{0}-2 \delta_{p_{1}}^{2} d-2 \delta_{p_{2}}^{2} d \quad \text { e, portanto, } \\
& \mu_{2}=\mu_{1}-2 \delta_{p_{2}}^{2} d
\end{aligned}
$$

Para vários locos (onde $i=$ número de locos), tem-se:

$$
\begin{aligned}
& \mu_{1}=\mu_{0}-2 \sum_{i} \delta_{p_{i}}^{2} d_{i} \mathbf{e}, \\
& \mu_{2}=\mu_{0}-2 \sum_{i} \delta_{p_{1}}^{2} d_{i}-2 \sum_{i} \delta_{p_{2}}^{2} d_{i}, \quad \mathbf{e}, \\
& \mu_{2}=\mu_{1}-2 \sum_{i} \delta_{p_{2}}^{2} d_{i}
\end{aligned}
$$

Portanto, a média da amostra é igual a média da população original menos o dobro do efeito da deriva genética. Nota-se que os efeitos da deriva genética nas médias serão mais pronunciados nos caracteres com graus de dominância ( $(d)$ mais elevados, e para ausência de dominância ( $(=0) \mu_{1}=\mu_{0}$ qualquer que seja o nivel de deriva ocorrido.

Analisando o desempenho das subpopulações nas gerações de amostragem temos então ( $t$ representa a geração de amostragem); 


\begin{tabular}{cccc}
$\mu_{s u b 1}$ & $=\mu_{p}-2 \delta_{p 1, d}^{2} d$ \\
$\mu_{s u b 2}$ & $=$ & $\mu_{p}-2 \delta_{p 2, r}^{2} d$ \\
$\ldots$ & $\ldots$ & $\ldots$ \\
$\mu_{s u b 10}$ & $=\mu_{p}-2 \delta_{p 10, d}^{2} d$ \\
\hline $\bar{\mu}_{s u b}=$ & $\mu_{p}-2 \bar{\delta}_{p p d}^{2} d$
\end{tabular}

onde $\mu_{\text {sub }}$ representa a média da subpopulação da amostra da geração $t, \mu_{p}$ a média da amostra da população ou subpopulação de onde a amostra da geração $t$ foi obtida e $2 \delta_{p t}^{2} d$ é o efeito da deriva genética da geração $t$ considerada.

Os contrastes entre médias das populações de origem com as subpopulações foram utilizadas para se estimar os efeitos da deriva genética de cada subpopulação na primeira geração de amostragem, isto é:

$$
\left(\mu_{\text {pop }}-\mu_{\text {sub }}\right)^{1}=2 \sum_{i} \delta_{p_{1 i}}^{2} d_{i} .
$$

e os contrastes entre a média da população de origem e a média geral das subpopulações foram utilizadas para estimar o efeito geral da deriva genética na primeira geração de amostragem, isto é:

$$
\left(\mu_{\text {pop }}-\mu_{\text {geralsubpops }}\right)^{1}=2 \sum_{i} \overline{\delta_{\bar{P}_{1 i}}^{2} d_{i}}
$$

Da mesma forma, para a segunda geração de amostragem, esses contrastes foram utilizados para se estimar os efeitos acumulativos da deriva genética para cada subpopulação e o efeito geral acumulativo, isto é:

$$
\left[\mu_{\text {pop }}-\left(\mu_{\text {subpopi }}\right)^{2}\right]=2 \sum_{i} \delta_{p_{1} i}^{2} d_{i}+2 \sum_{i} \delta_{p_{21}}^{2} d_{i}
$$




$$
\left[\mu_{\text {pop }}-\left(\mu_{\text {geralsubpopi }}\right)^{2}\right]=2 \sum_{i} \overline{\delta_{p_{i i}}^{2} d_{i}}+2 \sum_{i} \overline{\delta_{p_{2 i}}^{2} d_{i}}
$$

os contrastes entre as médias das subpopulções em diferentes gerações de amostragem permitiram estimar os efeitos da deriva genética que ocorreram entre a primeira e segunda gerações e os contrastes entre as médias gerais das subpopulações da primeira e segunda gerações permitiram estimar o efeito médio da deriva genética que ocorreu entre essas duas gerações de amostragem, isto é:

$$
\left[\left(\mu_{\text {subpopi }}\right)^{1}-\left(\mu_{\text {subpopi }}\right)^{2}\right]=2 \sum_{i} \delta_{p_{2 i}}^{2} d_{i}
$$

e o efeito geral da deriva genética na segunda geração,

$$
\left[\left(\mu_{\text {geralsubpop }}\right)^{1}-\left(\mu_{\text {geralsubpop }}\right)^{2}\right]=2 \sum_{i} \overline{\delta_{p_{2 i}}^{2} d_{i}}
$$

Estes contrastes foram testados mediante 0 " teste $t$ ", conforme Nogueira (1994). Mesmo que alguns contrastes do item 3.3.1 forem não significativos, o teste foi realizado, porque sendo a deriva genética aleatória e dependendo do controle genético do caráter, esse contraste pode, em teoria, não refletir as mudanças genéticas que possam vir a ocorrer em cada subpopulação em decorrência da endogamia. 


\subsubsection{Estimativas da variabilidade fenotipica}

As médias, os valores máximos e mínimos observados, assim como, a amplitude de variação de cada subpopulação nas duas gerações de amostragens das duas populações de origem, estão apresentadas em tabelas e gráficos de distribuição de freqüências.

A seguir as distribuições de freqüência para três caracteres (PG, AP e $A E$ ), das populações de origem e respectivas subpopulações foram submetidados aos testes de normalidade, assimetria e curtose. Assim, os dados foram testados para normalidade pelo teste 'W' (Dias, 1995), onde os valores de $W$ que são muito pequenos indicam que os dados não estão ajustados a uma distribuição normal..

Também foram feitas análises para assimetria e curtose, de acordo com a metodologia apresentada por Beiguelman (1991). Os desvios da simetria podem ser significativos para a direita (assimetria positiva) ou para a esquerda (assimetria negativa), significando que o alongamento de uma das caudas da distribuição pode ser a direita ou a esquerda. Para tanto, foi estimado o parâmetro $a_{3}$, que é o coeficiente de assimetria (Dias, 1995):

$$
a_{3}=\frac{n}{(n-1)(n-2)} \sum_{i=1}^{n}\left(x_{i}-\bar{x}\right)^{3} / s^{3}
$$

onde, $n=$ número de observações,

$s^{3}=$ é o cubo do desvio padrão da amostra,

$x_{i}=$ valor observado,

$\bar{x}=$ média geral

Para verificar a significância, obtem-se um valor $t$ que deve ser comparado a um $t$ crítico com infinitos graus de liberdade ao nivel de significância de $5 \%\left(t_{c}= \pm 1,960\right)$. Um valor de $t$ igual ou maior que 1,960 
indicará que a assimetria é positiva, ao passo que um valor de $t$ igual ou inferior que -1,960 indicará que a assimetria é negativa (Beiguelman, 1991).

A curtose indica o grau de concentração dos valores de uma variável contínua em torno da média, tomando-se a curva normal como referência. Assim, quando há um excesso de valores próximos á média, propiciando uma forma pontuda ao gráfico representativo da distribuição, diz-se que tal distribuição é leptocúrtica. Quando ocorre o oposto, isto é, um achatamento da curva representativa da distribuição unimodal, diz-se que ela é platicúrtica (Beiguelman, 1991). Para estimá-la, foi empregado o parâmetro $a_{4}$, (Dias, 1995):

$$
a_{4}=\frac{n(n-1)}{(n-1)(n-2)(n-3)} \frac{\sum_{i=1}^{n}\left(x_{i}-\bar{x}\right)^{4}}{s^{4}}-\frac{3(n-1)(n-1)}{(n-2)(n-3)}
$$

onde, $n=$ número de observaçiōes,

$\mathrm{s}^{4}=$ é o desvio padrão da amostra elevado a quarta potência ,

$x_{i}=$ valor observado,

$\bar{x}=$ média geral

Para verificar a significância, obtem-se um valor $t$ que deve ser comparado a um $\mathrm{t}$ crítico com infinitos graus de liberdade ao nivel de significância de $5 \%\left(t_{c}= \pm 1,960\right)$. Um valor de $t$ igual ou maior que 1,960 indicará que a distribuição e leptocúrtica. Em oposição, um valor de $t$ igual ou inferior que -1,960 indicará que a distribuiçãoe platicúrtica (Beiguelman, 1991).

Finalmente foram realizadas as comparações das variâncias fenotípicas das subpopulações para cada caráter avaliado. A variância fenotípica das subpopulações da primeira geração de amostragem foi comparada com as respectivas variâncias fenotípicas das subpopulações da segunda geração. Assim como a variância fenotípica da população de origem 
foi comparada com as respectivas variâncias fenotípicas das subpopulações nas duas gerações, utilizando-se o 'teste F' bilateral (Sokal \& Rohlf, 1981):

$$
F=\frac{\sigma_{\text {subpop1 }}^{2}}{\sigma_{\text {subpop 2 }}^{2}},
$$

onde;

$\sigma_{\text {subpopl }}^{2}=$ variância fenotípica da subpopulação e/ou população de origem de maior magnitude e $\sigma_{\text {subpop2 }}^{2}=$ variância fenotípica da subpopulação e/ou população de origem de menor magnitude, com $n_{1}$ e $n_{2}$ graus de liberdade associados respectivamente.

Se o $\mathrm{F}$ calculado for menor ou igual que o $\mathrm{F}$ tabelado (tabela de $\mathrm{F}$ bilateral) ao nível de $5 \%$ de significância, então $H_{0}: \sigma_{\text {sutpop1 }}^{2}=\sigma_{\text {sulpop } 2}^{2}$, isto é, assumem-se que as variâncias não diferem. Se o $\mathrm{F}$ calculado for maior que o $\mathrm{F}$ tabelado ao nível de $5 \%$ de significância, então $H_{1}: \sigma_{\text {sutpop } 1}^{2} \neq \sigma_{\text {sutpop } 2}^{2}$, isto é, assume-se que as variâncias diferem. 


\section{RESULTADOS E DISCUSSÃO}

Os processos da deriva genética e endogamia, que alteram a estrutura genética das populações, em decorrência de amostragem e suas conseqüências teóricas, encontram-se descritos em detalhes (Falconer \& Mackay, 1996). Entretanto estimativas desses processos em populações que sofrem ou sofreram alguma redução de seu tamanho efetivo em espécies vegetais não são frequentes. Antes de poder-se atribuir justificadamente efeitos à deriva genética, deve-se portanto, saber se o tamanho efetivo da população é suficientemente pequeno, se as subpopulações estão suficientementes bem isoladas e por último se estas não estão sujeitas a efeitos seletivos.

Neste estudo, tomou-se o cuidado de trabalhar com populações consideradas ideais a fim de reduzir o processo de mudanças nas freqüências alélicas à sua forma mais simples de análise (Falconer \& Mackay, 1996). Para isso, duas populações de milho (BR-105 e BR-106), na qual os acasalamentos se realizaram ao acaso, cada uma delas foi subdivididas em 10 subpopulações e duas gerações de amostragens. As condições especificas simplificadas para a população ideal foram as seguintes: 0 acasalamento foi restrito a indivíduos da mesma subpopulação através de cruzamentos controlados, porém ao acaso. As subpopulações foram então isoladas para impedir o fluxo gênico de uma subpopulação para outra, excluindo a migração; as duas gerações foram distintas e não se sobrepuseram; o número de indivíduos que se acasalaram em cada subpopulação foi o mesmo em todas as subpopulações e gerações. 
Como cada planta tem tamanho efetivo ( $\mathrm{Ne}$ ) igual a 1,0, o tamanho efetivo de cada subpopulação é $\mathrm{Ne}=5$; não houve seleção em nenhum estádio; e finalmente, a mutação foi desconsiderada.

\subsection{Análise de Variâncias}

A precisão dos experimentos realizados para verificar 0 desempenho das populações "per se" e da deriva genética, avaliada através do coeficiente de variação (CV \%), foi boa em todos os locais e para todos os caracteres avaliados (Tabelas 04 a 08). O menor valor do CV foi observado no

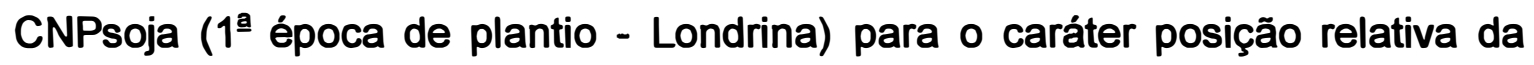
espiga na planta $(3,16 \%)$ e o maior, no mesmo local mas para a $2^{\text {a }}$ época de plantio, para produção de grãos por hectare $(13,99 \%)$, sendo esta tendência constante nos demais locais. Deve-se mencionar que as estimativas dos coeficientes de variação obtidas neste estudo, encontram-se dentro dos limites aceitáveis para experimentação agronômica e assemelham aos valores encontrados na literatura da cultura do milho, para todas as características avaliadas e, também, nos trabalhos sobre subpopulações de tamanho reduzido em milho (Corrales Blandón, 1996; Paterniani, 1995 ; Rezende, 1997).

As análises de variância individuais, por local, detectaram diferenças altamente significativas $(P<0,01)$ entre os tratamentos, para todos os caracteres avaliados. Isso se deve ao fato de haver grande diferença entre as populações de origem (Lanza et al., 1997; Naspolini Filho et al., 1981; Souza Jr., et al., 1993) e devido a diferenciação das subpopulações e/ou diferenças entre os hibridos comerciais. As análises de variância conjuntas, (Tabela 09) evidencia as diferença altamente significativas $(P<0,01)$ entre os tratamentos para todos os caracteres avaliados. Houve significância para 
ambientes para todas as características avaliadas, o que era esperado em função das diferentes condições dos ambientes em questão.

Observam-se significâncias para a primeira $\left(G_{1}\right)$ e segunda $\left(G_{2}\right)$ geração de amostragem para as duas populações (BR-105 e BR-106) e para todos os caracteres avaliados, o que indicam que as subpopulações de cada população em cada geração diferiram, indicando que os efeitos da deriva genética se evidenciaram. Entretanto, o contraste entre $G_{1}$ vs $G_{2}$ não foi significativo para todos os caracteres avaliados, indicando que em média as duas gerações não diferiram, não evidenciando efeito médio da deriva genética entre as médias gerais das geraçōes de amostragem. Este contraste foi significativo apenas para os caracteres AE e $r$ da população BR-105 e AP e AE da população BR-106, que neste caso indica que em média as duas gerações se diferem como esperado devido o efeito da deriva genética.

O contraste entre a população BR-105 e as médias das subpopulações nas duas gerações de amostragem (BR-105 vs $G_{1}$ e $G_{2}$ ) foi significativo apenas para o caráter $A E_{2}$ e com relação a população $B R-106$ o contraste entre a populaçāo $e$ as médias das subpopulações nas duas gerações de amostragens $\left(G_{1} \in G_{2}\right)$ foi significativo apenas para o caráter $P$. Indicando que as populações de origem não diferem das médias gerais das subpopulações das gerações $G_{1}$ e $G_{2}$ na maioria dos caracteres.

Pela análise de variância observa-se significância para a interação tratamentos $\times$ locais, indicando que o comportamento das populações, subpopulações e híbridos nos cincos ambientes não devem ser consistentes. Isto já era esperado, uma vez que os ambientes escolhidos sâo muito distantes entre si e diferem quanto ao regime de chuvas e ao tipo de fertilidade dos solos. Mas, embora haja interação significativa de tratamentos $x$ locais há efeitos significativos das subpopulações da BR-105 e BR-106 em G e $G_{2}$, para todos os caracteres avaliados, que se sobrepoem a essas variações da interação.de maneira que é possivel avaliar as subpopulações para todos os locais, e não apenas de um local individualmente. 


\subsection{Efeitos da deriva genética sobre as médias dos caracteres}

As médias das populações BR-105 e BR-106 e as respectivas médias das subpopulações da primeira $\left(G_{1}\right)$ e segunda geração $\left(G_{2}\right)$ de amostragem de tamanho $\mathrm{Ne}=5$ estão apresentadas nas Tabelas 10 e 11, respectivamente, para os caracteres produção de grãos - $P$ - (ton/ha), altura da planta - AP - (cm/pl), altura da espiga - AE - (cm/pl), prolificidade - PRO (esp./pl.) e posição relativa da espiga - $r$ - (AE/AP). As subpopulações oriundas das populações BR-105 e BR-106 apresentaram diferenças estatisticas ao nivel de $5 \%$ de probabilidade pelo teste de Tukey, para os cinco caracteres e nas duas gerações de amostragens, exceto para a geração $G_{1}$ para os caracteres P e PRO da população BR-106.

Observou-se no geral, que a produtividade da população BR-106 (9,11 ton/ha) e suas respectivas subpopulaçōes das gerações $G_{1}$ e $G_{2}$ de amostragem foram superiores às produtividades da população BR-105 (7,94 ton/ha) e suas respectivas subpopulações. Para os caracteres AP, AE e $r$ a população BR-105 apresentam médias superiores a BR-106. A população BR$106(0,93 \mathrm{esp} / \mathrm{pl})$ tem em média prolificidade maior que da população BR-105 $(0,91 \mathrm{esp} / \mathrm{pl})$, mostrando que as populações se diferem, assim como as respectivas subpopulações.

A média da produção de grãos por ha $(P)$ da população BR-105 foi de 7,94 ton/ha, sendo que na primeira geração de amostragem $\left(G_{1}\right)$ as maiores médias foram das subpopulações $4(7,99$ ton/ha) e $5(7,85$ ton/ha) e a menor a da subpopulação 3 (6,66 ton/ha), sendo a amplitude de variação de 1,33 ton/ha. Na segunda geração $\left(G_{2}\right)$, a amplitude de variação foi de 1,58 ton/ha, sendo superior a $G_{1}$. As maiores médias foram das subpopulações 2 . (8,02 ton/ha), 10 (7,87 ton/ha), 4 (7,74 ton/ha), 1 (7,72 ton/ha), 7 (7,62 ton/ha), 8 e 9 (7,57 ton/ha) e não diferiram estatísticamente pelo teste de Tukey a $5 \%$ e a menor produção foi da subpopulação 3 (6,44 ton/ha). Porém observou-se em 
$\mathrm{G}_{1}$ uma menor diferenciação entre as subpopulações, embora a diferença seja pequena. As subpopulações oriundas da população da BR-105, cuja produtividade foi de 7,94 ton/ha, apresentaram uma subpopulação com média superior e 9 subpopulações com médias inferiores a população nas gerações $G_{1}$ e $G_{2}$. Para a população BR-106, cuja produtividade foi de 9,11 ton/ha, não observaram-se diferenças estatísticas das médias das subpopulações em $\mathrm{G}_{1}$ e nenhuma subpopulação apresentou valor superior a mesma, tanto em $G_{1}$ quanto em $\mathrm{G}_{2}$. Mas, observa-se em $\mathrm{G}_{1}$ que a diferença entre a subpopulação mais produtiva ( 8,92 ton/ha - subpopulação 2$)$ e a menos produtiva $(7,91$ ton/ha - subpopulação 4) a amplitude foi de 1,01 ton/ha que é um valor agronomicamente expressivo em termos de produção por hectare. A geração $\mathrm{G}_{2}$ apresentou diferenças significativas entre as subpopulações, sendo a subpopulação $7(9,02$ ton/ha) com a maior média e as subpopulações $10(7,70$ ton/ha), $6(7,69$ ton/ha) e $9(7,64$ ton/ha $)$ com as menores médias, apresentando uma amplitude de variação de 1,38 ton/ha, sendo superior a $\mathbf{G}_{1}$. Houve um aumento da amplitude de variação para o caráter $P$ em $G_{2}$ comparado a $G_{1}$ para as duas populações, sendo que a população BR-105 apresentou maiores amplitudes em $\mathrm{G}_{1}$ e $\mathrm{G}_{2}$ comparadas a população BR-106.

Para o caráter AP a subpopulação que apresentou maior médias foi a subpopulação $4(237,03 \mathrm{~cm} / \mathrm{pl})$ e a menor média foi a subpopulação 1 $(211,67 \mathrm{~cm} / \mathrm{pl})$ em $\mathrm{G}_{1}$ e em $\mathrm{G}_{2}$ a maior média foi da subpopulação $4(234,80$ $\mathrm{cm} / \mathrm{pl}$ ) e a menor média da subpopulação $9(215,34 \mathrm{~cm} / \mathrm{pl})$, para a população BR-105 que teve uma média de 226,15 cm/pl. Para a BR-106 $(224,08 \mathrm{~cm} / \mathrm{pl})$ variaram da subpopulação $7(234,92 \mathrm{~cm} / \mathrm{pl})$, a maior média, e a subpopulação 9 $(221,81 \mathrm{~cm} / \mathrm{pl})$, subpopulação $5(221,62 \mathrm{~cm} / \mathrm{pl})$ e subpopulação $3(221,39$ $\mathrm{cm} / \mathrm{pl})$, com menores médias, em $\mathrm{G}_{1}$. $E m \mathrm{G}_{2}$, a subpopulação $2(232,38 \mathrm{~cm} / \mathrm{pl})$ e a subpopulação $7(231,81 \mathrm{~cm} / \mathrm{pl})$ tiveram as maiores médias e a subpopulação $3(211,34 \mathrm{~cm} / \mathrm{pl})$ e a subpopulação $9(214,82 \mathrm{~cm} / \mathrm{pl})$, tiveram as menores médias. Observou-se uma amplitude de variação entre as subpopulações em $\mathrm{G}_{1}$ de $25,36 \mathrm{~cm} / \mathrm{pl}$ para BR-105 e $13,53 \mathrm{~cm} / \mathrm{pl}$ para BR-106. Observou-se um 
comportamento inverso em $\mathrm{G}_{2}$, onde a amplitude entre as subpopulações da BR-106 $(21,04 \mathrm{~cm} / \mathrm{pl})$ foi superior a BR-105 $(19,46 \mathrm{~cm} / \mathrm{pl})$. Pode-se observar que as médias das subpopulações apresentaram valores inferiores e superiores em relação as médias das populações de origem.

Com relação ao caráter $A E$, as subpopulações variaram da maior média a subpopulação $4(140,02 \mathrm{~cm} / \mathrm{pl})$ e a menor média da subpopulação 1 $(123,12 \mathrm{~cm} / \mathrm{pl}) \mathrm{com}$ amplitude de variação de $16,90 \mathrm{~cm} / \mathrm{pl}$ para $G_{1}$, e da maior média da subpopulação $4(139,84 \mathrm{~cm} / \mathrm{pl})$ a menor média da subpopulação 9 (123,35 cm/pl) com amplitude de variação de $16,49 \mathrm{~cm} / \mathrm{pl}$, em $\mathrm{G}_{2}$, da população BR-105 (132,52 cm/pl). Para a população BR-106 com média de 129,18 cm/pl, as médias das subpopulações variaram da maior média da subpopulação 2 $(136,02 \mathrm{~cm} / \mathrm{pl})$ as menores médias das subpopulações $3(127,65 \mathrm{~cm} / \mathrm{pl})$ e subpopulação $5(127,80 \mathrm{~cm} / \mathrm{pl})$, com amplitude de variação de $8,22 \mathrm{~cm} / \mathrm{pl} \mathrm{em}$ $\mathrm{G}_{1}$, e a maior média da subpopulação $2(137,07 \mathrm{~cm} / \mathrm{pl})$ e as menores médias da subpopulação $10(126,43 \mathrm{~cm} / \mathrm{pl})$, subpopulação $3(124,66 \mathrm{~cm} / \mathrm{pl})$, subpopulação $5(123,84 \mathrm{~cm} / \mathrm{pl})$ e subpopulação $9(122,97 \mathrm{~cm} / \mathrm{pl}) \mathrm{com}$ amplitude de variação de $14,10 \mathrm{~cm} / \mathrm{pl}$ em $\mathrm{G}_{2}$. As subpopulações apresentam valores que são inferiores e superiores as populações de origem (BR-105 e BR-106).

. Para o caráter prolificidade (PRO) as populações BR-105 e BR106 apresentaram 0,91 e 0,93 esp/pl de médias, respectivamente. As médias das subpopulações variaram da subpopulação 5 (0,93 esp/pl), subpopulação 7 (0,92 esp/pl) e subpopulação $4(0,91 \mathrm{esp} / \mathrm{pl})$, as maiores médias, a subpopulação 9 (0,82 esp/pl) e subpopulação 3 (0,81 esp/pl) com menores médias, em $G_{1}$. Variaram da subpopulação $10(0,96 \mathrm{esp} / \mathrm{pl})$ a subpopulação (3 0,82 esp/pl) na geração $G_{2}$, para a população BR-105. Para a população BR106 , as médias das subpopulações variaram de subpopulação $4(0,94 \mathrm{esp} / \mathrm{pl})$ a subpopulação $10(0,86 \mathrm{esp} / \mathrm{pl})$ em $\mathrm{G}_{1}$, e da subpopulação $7(0,99 \mathrm{esp} / \mathrm{pl})$ a subpopulação $10(0,84 \mathrm{esp} / \mathrm{pl})$ esp/pl em $\mathrm{G}_{2}$. Comparando as duas gerações, a amplitude de variação entre as subpopulações da BR-106 foi de 0,08 e 0,15 esp./pl, respectivamente. Sendo uma diferença expressiva de amplitude em $\mathbf{G}_{2}$ 
comparado a amplitude em $\mathrm{G}_{1}$ para a população BR-106. Para população BR105 a amplitude de variação nas duas gerações foram de 0,12 e 0,14 esp./pl para as gerações $G_{1}$ e $G_{2}$, respectivamente.

A maior média obtida para posição relativa da espiga ( $r$ ) na população BR-105 foi da subpopulação 7 (0,60 AE/AP) em $G_{1}$ e das subpopulações 3,4 e 5 (0,59 AE/AP) em $G_{2}$, e as menores médias foram 0,57 tanto para $G_{1}$ quanto para $G_{2}$. A população $B R-106$ obteve médias superiores e inferiores iguais em $G_{1}$ e $G_{2}$ correspondentes 0,59 AE/AP e a 0,56 AE/AP, respectivamente. Apresentando as amplitudes de variação nas duas gerações da população BR-106 igual a 0,03 AE/AP e na população BR-105 com valores de 0,03 AE/AP em $G_{1}$ e 0,02 AE/AP em $G_{2}$.

Observou-se de uma maneira geral que para a população BR-105 a subpopulação 4 obteve uma desempenho superior para os cincos caracteres nas gerações $G_{1}$ e $G_{2}$, exceto para o caráter PRO $\left(G_{2}\right)$. As subpopulações 3 e 9 tiveram desempenho inferior para a maioria dos caracteres avaliados. Para a população BR-106 as subpopulações 2 e 7 tiveram desempenho superior e a subpopulação 9 desempenho inferior para os caracteres $P, A P$ e $A E$ em $G_{1}$ e $G_{2}$. Observou-se também que a subpopulaçāo 10 teve desempenho inferior em $G_{1}$ e $G_{2}$ para os caracteres PRO e $r$ e as subpopulações 5,6 e 7 tiveram desempenho superior para o caráter PRO em $G_{1}$ e $G_{2}$ e as subpopulações 4, 2 e 3 tiveram desempenho superior em $G_{1}$ e $G_{2}$ para o caráter $r$.

As médias das subpopulaçōes tenderam a diferenciar-se da média da população de origem, em conseqüência da deriva genética causada pelo tamanho reduzido da amostra $(\mathrm{Ne}=5)$ e do efeito da endogamia, induzida pelo tamanho efetivo reduzido. Cada loco que controla um caráter quantitativo terá sua freqüência alterada na próxima geração que será tanto mais próxima da população de origem quanto maior for o tamanho da amostra. Sob a hipótese de que a deriva genética é não direcional, espera-se que a freqüência alélica média nas subpopulações se aproxime da freqüência alélica da população de origem; consequentemente, a média de um caráter quantitativo 
nas subpopulações deve se distribuir em igual proporção em valores superiores e inferiores à população de origem. Entretanto, este resultado só é esperado para caracteres sem dominância. De fato, o tamanho reduzido causa um aumento na freqüência de homozigotos em conseqüência da endogamia, com taxa média de endogamia esperado de $F_{1}=(1 / 2 \mathrm{Ne})$ e $\mathrm{F}_{2}=(1 / 2 \mathrm{Ne})+[1-(1 / 2 \mathrm{Ne})] \mathrm{F}_{1}$, para cada uma das subpopulações da primeira e segunda geração de amostragem, respectivamente. Como neste caso, $\mathrm{Ne}=5$, resultando em $\mathrm{F}_{1}=10 \%$ e $\mathrm{F}_{2}=19 \%$ (Crow \& Kimura, 1970; Falconer \& Mackay, 1996). A depressão por endogamia é dada por $2 F \sum_{i} p_{i} q_{i} d_{i}$, sendo portanto função das freqüências alélicas $(p$ e $q)$ e da dominância (d). Consequentemente, quanto maior for os niveis de dominância dos locos controlando o caráter, maior será a diferença das subpopulações em relação à média da população de origem; e maior será a proporção de subpopulações com média inferior à média da população de origem, (Falconer \& Mackay, 1996).

Rezende (1997) estudou a contribuição dos locos em homozigose ou dos efeitos aditivos e a contribuição dos locos em heterozigose ou dos efeitos de dominância para o ciclo 0 de seleção recorrente para as populações BR-105 e BR-106 e observou que para o caráter peso de espigas havia uma evidência de forte preponderância dos efeitos de dominância em ambas as populações. Para os caracteres altura da planta e da espiga, houve contribuição significativa dos efeitos aditivos e de dominância para as duas populações , porém com predominância dos efeitos aditivos. Já para a posição relativa da espiga na planta, somente os efeitos aditivos contribuiram nas populações, e com relação a prolificidade, os dois tipos de efeitos, aditivo e dominante, contribuíram, não ocorrendo uma tendência marcante de predominância entre eles. Varios autores trabalhando com diferentes populações de milho também informam sobre a predominância dos efeitos de 
dominância para o caráter produção de grão (Eyherabide \& Hallauer, 1991; Helms et al., 1989; Keeratinijakal \& Lamkey, 1993; Smith 1979; Smith, 1983).

Como os efeitos de dominância sâo importantes para o caráter $P$, espera-se que ele seja mais sensivel aos efeitos da deriva genética. Observouse nas subpopulações da população BR-105 e BR-106, principalmente a BR106 que todas as médias das subpopulações foram inferiores a população de origem para o caráter $\mathrm{P}$. Este fato pode ter ocorrido devido ao efeitos de dominância deste caráter, sendo que, a população BR-105 por ser uma população obtida da seleção entre progênies $S_{1}$ é menos sensível à depressão por endogamia (Souza Jr et al., 1993). Com relação aos efeitos aditivos eles são mais importantes para os caracteres $A P, A E, P R O$ e $r$ e foram observados valores superiores e inferiores a população de origem para estes caracteres..

\subsection{Estimativas dos efeitos da deriva genética.}

As Tabelas 12 e 13 apresentam os valores dos contrastes das médias das subpopulações nas duas gerações de amostragens de tamanho efetivo restrito $(\mathrm{Ne}=5)$ em relação às populações de origem. Estes contrastes foram utilizados para estimar os efeitos da deriva genética de cada subpopulação na primeira geração e o efeito acumulativo da deriva genética na segunda geração de amostragem, respectivamente, isto é os contrastes:

$$
\begin{aligned}
& \text { 1) }\left[\mu_{\text {pop }}-\left(\mu_{\text {subpopi }}\right)^{1}\right]=2 \sum_{i} \delta_{p_{1 i}}^{2} d_{i} . \\
& \text { 2) }\left[\mu_{\text {pop }}-\left(\mu_{\text {supopi }}\right)^{2}\right]=2 \sum_{i} \delta_{p_{i} i}^{2} d_{i}+2 \sum_{i} \delta_{p_{2 i}}^{2} d_{i},
\end{aligned}
$$


Os valores dos contrastes das médias gerais das subpopulações das duas gerações de amostragens de tamanho restrito $(\mathrm{Ne}=5)$ em relação às populações de origem foram utilizados para estimar o efeito médio geral da deriva genética na primeira geração e o efeito médio geral acumulativo da deriva genética nas duas gerações de amostragem, respectivamente, isto é:

3) $\left[\mu_{\text {pop }}-\left(\mu_{\text {geralsubpopi }}\right)^{1}\right]=2 \sum_{i} \overline{\delta_{p_{i i}}^{2} d_{i}}$

4) $\left[\mu_{\text {pop }}-\left(\mu_{\text {geralsubpopi }}\right)^{2}\right]=2 \sum_{i} \overline{\delta_{p_{i i}}^{2} d_{i}}+2 \sum_{i} \overline{\delta_{p_{2 i}}^{2} d_{i}}$.

E as Tabelas 14 e 15 apresentam os valores dos contrastes das médias das subpopulações da primeira geração $\left(G_{1}\right)$ em relação a segunda geração $\left(G_{2}\right)$ que representa genéticamente os efeitos da deriva genética na segunda geração de amostragem:

5) $\left[\left(\mu_{\text {subpopi }_{i}}\right)^{1}-\left(\mu_{\text {subpopi }_{i}}\right)^{2}\right]=2 \sum_{\mathrm{i}} \delta_{\mathrm{p}_{2 i}}^{2} \mathrm{~d}_{\mathrm{i}}$.

E os valores dos contrastes das médias gerais das subpopulações da primeira geração $\left(G_{1}\right)$ em relação a segunda geração $\left(G_{2}\right)$ representa o efeito médio geral da deriva genética na segunda geração, isto é:

6) $\left[\left(\mu_{\text {geralsubpopi }}\right)^{1}-\left(\mu_{\text {geralsubpopp }}\right)^{2}\right]=2 \sum_{i} \overline{\delta_{p_{2 i}}^{2} d_{i}}$.

Valores positivos significam que a média da população de origem foi superior a média da subpopulação (em $\mathrm{G}_{1}$ elou $\mathrm{G}_{2}$ ) ou que a média da subpopulação em $G_{1}$ foi superior a respectiva média em $G_{2}$. Valores negativos significam o contrário. Estes valores positivos e negativos significam , conforme Falconer \& 
Mackay (1996), que a deriva genética contribui aleatoriamente para o aumento ou diminuição da média do caráter.

Valores positivos e negativos dos efeitos da deriva genética foram observados para os cincos caracteres e nas duas gerações de amostragens $\left(G_{1}\right.$ e $\left.G_{2}\right)$ indicando que a deriva genética contribuiu para aumentar ou diminuir a média do caráter (Tabelas 12, 13, 14 e 15).

Para o caráter produção de grãos (Tabelas 12 e 13), o efeito da deriva genética em cada subpopulação em $\mathrm{G}_{1}$ (contraste 1 ), observou-se que a população BR-105 apresentou valores positivos e negativos e em seis subpopulações obtiveram-se contrastes positivos e significativos.Significando que a deriva genética diminuiu a média do caráter. $O$ maior efeito significativo da deriva genética em $G_{1}$, (contraste 1), para a população BR-105, foi de 1270 $\mathrm{Kg} / \mathrm{ha}$ (subpopulação 3) e o menor foi de $480 \mathrm{Kg} / \mathrm{ha}$ (subpopulação 1). $O$ efeito acumulativo da deriva genética em $\mathrm{G}_{2}$ (contraste 2), foram observados para as subpopulações 3,5 e 6 , conforme esperado. A subpopulação 3 reduziu em $1490 \mathrm{Kg} / \mathrm{ha}$, a subpopulação 5 reduziu em $720 \mathrm{Kg} / \mathrm{ha}$ e a subpopulação $6 \mathrm{em}$ $770 \mathrm{Kg} / \mathrm{ha}$ em relação a população BR-105 Esses valores de redução são agronômicamente expressivos para o caráter produção de grãos por ha. Comportamentos diferentes também foram observados para a deriva genética, na subpopulação 2 que em $G_{1}$ (contraste 1) ocorreu uma redução de 1270 $\mathrm{Kg} / \mathrm{ha}$, e em $\mathrm{G}_{2}$, o efeito acumulado (contraste 2), ocorreu um acréscimo de 70 $\mathrm{Kg} / \mathrm{ha}$, inferior quando comparado ao efeito em $\mathrm{G}_{1}$. Outras situações ocorreram como a subpopulação 4 que sofreu um acréscimo de $50 \mathrm{Kg} / \mathrm{ha}$ em $\mathrm{G}_{1}$ (contraste 1), porém em $G_{2}$ (contraste 2), o efeito acumulado da deriva genética, sofreu uma redução de $170 \mathrm{Kg} / \mathrm{ha}$, apesar de ser não significativo estes valores. A subpopulação 9 sofreu redução na média em relação a BR105 de $1003 \mathrm{Kg} / \mathrm{ha} \mathrm{em} \mathrm{G}_{1}$ (contraste 1) e uma menor redução em $\mathrm{G}_{2}$ (contraste 2) de $360 \mathrm{Kg} / \mathrm{ha}$. Essas situações mostram comportamentos diferentes, os quais são previstos, de acordo com Falconer \& Mackay (1996), que dizem que 
a deriva genética é um processo aleatório em direção e predito somente em quantidade.

Para a BR-106 os efeitos da deriva genética nas subpopulações nas duas gerações tiveram comportamento semelhantes a população BR-105. Todos os valores da deriva genética em $G_{1}$ e $G_{2}$ (contraste 1 e 2) foram positivos significando que as subpopulações tiveram suas médias reduzidas nas duas gerações. Em 8 subpopulações 0 efeito da deriva genética em $\mathbf{G}_{1}$ (contraste 1) e o efeito acumulado em $\mathrm{G}_{2}$ (contraste 2) foram significativos. Valores que variaram de $410 \mathrm{Kg} / \mathrm{ha}$ (subpopulação 3) a $1200 \mathrm{Kg} / \mathrm{ha}$ (subpopulação 4) em $\mathrm{G}_{1}$ (contraste 1) e $520 \mathrm{Kg} / \mathrm{ha}$ (subpopulação 2) a 1470 $\mathrm{Kg} /$ ha (subpopulação 9) em $\mathrm{G}_{2}$ (contraste 2). Observa-se em $\mathrm{G}_{2}$ (contraste 2), que o efeito acumulado da deriva genética na subpopulação $1(620 \mathrm{Kg} / \mathrm{ha})$ e na subpopulação 4 (950 Kg/ha) foram inferiores ao obtidos em $G_{1}$ (contraste 1$)$. As subpopulações $5,6,8,9$ e 10 tiveram efeito acumulado da deriva genética (contraste 2).

Rezende, (1997) relatou o efeito da redução na heterozigose devido à deriva genética em populações (DQI), que é função do quadrado da alteração na freqüência do alelo favorável por deriva, e da contribuição dos locos em heterozigose $\left[\mathrm{DQI}=\Sigma\left(\delta_{\mathrm{p}}\right)^{2} \mathrm{~d}\right]$, para o caráter peso grãos, e observou valores de DQI negativo e significativo em ambas as populações, correspondendo a $-10,96 \mathrm{~g} / \mathrm{pl}(-609 \mathrm{Kg} / \mathrm{ha}$ ) na população BR-105 e a -30,46 g/pl (-1692 Kg/ha) na população BR-106. As estimativas negativas de DQI indicam que os efeitos da deriva genética limitaram o melhoramento para a produtividade de grãos nas populações per se. Estimativas de deriva genética em programas de seleção recorrente em diferentes populações de milho variaram de $-0,01$ ton/ha a $-0,36 \mathrm{Kg} / \mathrm{ha}$ (Eyherabide \& Hallauer, 1991; Helms et al., 1989; Keeratinijakal \& Lamkey, 1993; Smith 1979; Smith, 1983). Apesar das estimativas de DQI para produçao de grãos serem negativos, diminuindo o 
caráter, observa-se entre as subpopulações da população BR-105 valores da deriva genética que aumenta o caráter produção de grãos. Observa-se também, valores da deriva genética semelhantes aos valores de DQI, mas os valores de DQI estão influenciados pela seleção, pois a amostra não é aleatória, mas sim uma amostra selecionada. Mesmo assim, é importante o estudo da deriva genética, pois esta pode interferir aleatóriamente em programas de melhoramento alterando o ganho de seleção.

Para o caráter altura da planta (AP), o efeito da deriva genética nas subpopulações em relação a população $B R-105$ em $G_{1}$ (contraste 1), foram significativo para as subpopulações $1,4,8,9$ e 10 e variaram de $14,18 \mathrm{~cm} / \mathrm{pl}$ (subpopulação 1) a $6,36 \mathrm{~cm} / \mathrm{pl}$ (subpopulação 10), sendo que somente a subpopulação 4 obteve valor negativo significativo de deriva genética, significando que esta teve a média superior a população BR-105 e indicando que a deriva genética também pode contribui para o aumento da média do caráter AP, devido este processo ser aleatório.

Observou-se para a população BR-105, que o efeito acumulado da deriva genética em $\mathrm{G}_{2}$ (contraste 2 ), na subpopulação $1(10,46 \mathrm{~cm} / \mathrm{pl})$ e na subpopulação $4(-8,65 \mathrm{~cm} / \mathrm{pl})$ foram inferiores em relação ao efeito da deriva genética em $\mathrm{G}_{1}$ (contraste 1 ), apesar das duas subpopulaçãoulaçoes terem comportamento diferentes. A subpopulaçāo 1 sofreu redução na média e a subpopulação 4 sofreu aumentou da média devido a deriva genética. Apenas a subpopulação 9 teve um efeito acumulado da deriva genética (contraste 2) em relação a população BR-105. Para a população BR-106 apenas efeitos negativos da deriva genética foram significativos em $G_{1}$ (contraste 1): as subpopulações $2(-8,43 \mathrm{~cm} / \mathrm{pl}), 7(-10,84 \mathrm{~cm} / \mathrm{pl})$ e a subpopulação $10(-5,93$ $\mathrm{cm} / \mathrm{pl}$ ). $O$ efeito acumulado da deriva genética em $\mathrm{G}_{2}$ (contraste 2 ) ocorreu em algumas subpopulações reduzindo significativamente a média da subpopulação. Foram as subpopulações $3(12,74 \mathrm{~cm} / \mathrm{pl}), 9(9,26 \mathrm{~cm} / \mathrm{pl})$ e 5 $(5,85 \mathrm{~cm} / \mathrm{pl})$ que apresentaram efeitos da deriva genética relativamente 
acentuados e significativos quando comparado com os efeitos da deriva genética obtidos em $G_{1}$ (contraste 1). Estes efeitos da deriva genética obtidos são superiores ao obtidos por Rezende (1997), que relatou valores de DQI negativo e significativo em ambas as populações, correspondendo a $-8,18$ $\mathrm{cm} / \mathrm{pl}$ na população $\mathrm{BR}-105$ e a $-4,22 \mathrm{~cm} / \mathrm{pl}$ na população $\mathrm{BR}-106$. E estimativas de deriva genética em programas de seleção recorrente em diferentes populações de milho variaram de $0,45 \mathrm{~cm} / \mathrm{pl}$ a $-3,09 \mathrm{~cm} / \mathrm{pl}$ (Eyherabide \& Hallauer, 1991; Keeratinijakal \& Lamkey, 1993; Smith, 1983). Essa diferença pode ter ocorrido devido a influência da seleção na estimativa do parâmetro DQI.

Em relação a altura da espiga (AE), comportamento semelhante foi observado, a deriva genética contribuiu para aumentar e diminuir a altura da espiga. Os valores significativos das subpopulaçōes variaram de $9,40 \mathrm{~cm} / \mathrm{pl}$ (subpopulação 1) a 6,12 cm/pl (subpopulação 8) e 9,17 cm/pl (subpopulação 9) a 4,58 cm/pl (subpopulação 8) para a população BR-105 para os efeitos da deriva em $G_{1}$ e $G_{2}$ (contrastes 1 e 2), respectivamente. Para a população BR106 os valores da deriva genética em $G_{1}$ (contraste 1) foram de $-6,84 \mathrm{~cm} / \mathrm{pl}$ (subpopulação 2) e $-5,58 \mathrm{~cm} / \mathrm{pl}$ (subpopulação 7) e o efeito acumulado em $\mathrm{G}_{2}$ (contraste 2). foram de $-7,89 \mathrm{~cm} / \mathrm{pl}$ (subpopulação 2) e $5,34 \mathrm{~cm} / \mathrm{pl}$ (subpopulação 5). Valores que aumentaram e diminuíram o caráter $\mathrm{AE}$, no caso da população BR-106. Rezende, (1997) relatou valores da deriva genética que comparados a estes resultados, foram inferiores para a população BR-105 e superiores para a população BR-106, os valores de DQI correspondendo a $3,95 \mathrm{~cm} / \mathrm{pl}$ na população $\mathrm{BR}-105$ e a $-8,57 \mathrm{~cm} / \mathrm{pl}$ na população BR-106. Estimativas de deriva genética em programas de seleção recorrente em populações diferentes de milho variaram de $0,38 \mathrm{~cm} / \mathrm{pl}$ a $-2,28 \mathrm{~cm} / \mathrm{pl}$ (Eyherabide \& Hallauer, 1991; Keeratinijakal \& Lamkey, 1993; Smith, 1983). Lembrando que os valores de DQI estão influenciados pela seleção. 
Os caracteres PRO e $\mathrm{r}$ apresentaram poucas subpopulações com efeitos significativos da deriva genética em $G_{1}$ e efeito acumulativo em $G_{2}$ (contraste 1 e 2 ), em parte justificável pelo baixo envolvimento de efeitos dominantes nestes caracteres.A posição relativa da espiga ( $r$ ) não foi significativamente afetada pela deriva genética em nenhuma das populações estudadas mas, o parâmetro DQI, para o caráter prolificidade, se mostrou significativamente negativo (-1,70 esp/pl), indicando que a deriva ocorreu de maneira a reduzir o número de espigas por planta na população BR-105 (Rezende, 1997).

O que explica o fato do efeito da deriva genética podendo não ter um efeito cumulativo em $\mathrm{G}_{2}$ (contraste 2) ocorre porque, apesar do tamanho reduzido da amostra provocar a deriva genética, leva também a homozigose de locos sendo que não necessariamente essa homozigose está relacionada à depressão por endogamia. Segundo Souza Júnior (1995), a expressão $2 \sum_{i} \delta_{p_{i}}^{2} d_{i}=2 \sum_{i} p_{i} q_{i} d_{i} / 2 N e$, como a expressão $2 \sum_{i} p_{i} q_{i} d_{i}=D E$ (DE= depressão por endogamia) (Falconer \& Mackay, 1996), e a expressão $\Delta F=1 / 2 \mathrm{Ne}$, então a expressão da média da amostra para qualquer geração $t$ pode ser expressa: $\mu_{t}=\mu_{0}-F_{t} D E$, onde $F_{t}$ corresponde ao coeficiente de endogamia na t-ésima geração. Portanto, a alteração nas médias dos caracteres devido à deriva genética depende do tamanho efetivo da amostra e do grau de dominância dos caracteres em estudo. Evidentemente, quanto maior o tamanho efetivo da amostra menor será a alteração nas médias dos caracteres e viceversa. A alteração na média de um caráter depende, também, do seu grau de dominância. Assim, escolhendo caracteres cujos graus de dominância sejam elevados, detectam-se os efeitos da deriva genética, uma vez que se o grau de dominância for muito baixo $(d \approx 0)$ tem-se que: $\mu_{1} \approx \mu_{0}$ (Souza Júnior, 1995).

$O$ efeito médio geral da deriva genética em $G_{1}$ (contraste 3 ), média geral das subpopulações em $G_{1}$ em relação a população de origem, foram significativos para os caracteres P e PRO da população BR-105 e BR- 
106. $O$ efeito médio geral acumulado da deriva genética em $\mathrm{G}_{2}$ (contraste 4), a média geral das subpopulações em $\mathrm{G}_{2}$ em relação a população de origem, foi significativo apenas para o caráter produção de grãos das populaçãoes BR-105 e BR-106. Comprovando que este caráter, por ter mais efeitos dominantes atuando, sofreu mais com a deriva genética.

Finalmente, nas Tabelas 14 e 15 estão relacionados os efeitos da deriva genética entre as geraçōes $G_{1}$ e $G_{2}$ (contraste 5), para os cincos caracteres. Para o caráter produção de grãos e prolificidade observou-se valores positivos e negativos da deriva genética para os carateres na população BR-105. Valores negativos da deriva genética para o caráter $P$ foram das subpopulações $2(-750 \mathrm{Kg} / \mathrm{ha})$ e $9(-660 \mathrm{Kg} / \mathrm{ha})$; para o caráter PRO as subpopulações $9(-0,07$ esp/pl) e $10(-0,08$ esp/pl). A deriva genética diminuiu as médias das subpopulações $5(640 \mathrm{Kg} / \mathrm{ha})$ e $6(570 \mathrm{Kg} / \mathrm{ha})$ do caráter $\mathrm{P}$; as subpopulações $2(5,25 \mathrm{~cm} / \mathrm{pl})$ e $7(4,44 \mathrm{~cm} / \mathrm{pl})$ para o caráter $A E$; as subpopulações 2 (0,02 AE/AP), 7 (0,02 AE/AP) e 10 (0,02 AE/AP) para 0 caráter $r$. $O$ efeito médio geral da deriva entre as gerações $G_{1}$ e $G_{2}$ (contraste 6), foi significativo apenas para o caráter $A E(1,52 \mathrm{~cm} / \mathrm{pl})$ e $r(-0,01$ AE/AP). Significando que o efeito médio geral da deriva genética não foi significativo para a maioria dos caracteres.

A população BR-106 apresentou valores positivos e significativos da deriva genética entre as gerações (contraste 5), para as subpopulações 6 (590 KG/ha) e $8(490 \mathrm{Kg} / \mathrm{ha})$ para o caráter $P$; as subpopulações $3(10,05$ $\mathrm{cm} / \mathrm{pl}), 6(7,62 \mathrm{~cm} / \mathrm{pl})$ e $9(6,99 \mathrm{~cm} / \mathrm{pl})$ para o caráter AP; as subpopulações 6 $(5,73 \mathrm{~cm} / \mathrm{pl}), 7(4,33 \mathrm{~cm} / \mathrm{pl})$ e $9(5,32 \mathrm{~cm} / \mathrm{pl})$ para o caráter $A E$. E valores negativos da deriva genética para as subpopulações 7 (-0,07 esp/pl) para o caráter PRO e as subpopulações $3(-0,01$ AE/AP) e 7 (0,01 AE/AP) para o caráter r. $O$ efeito médio geral da deriva entre as gerações $G_{1}$ e $G_{2}$ (contraste 6), foi significativo para os caracteres $A P(3,18 \mathrm{~cm} / \mathrm{pl})$ e $A E(2,37 \mathrm{~cm} / \mathrm{pl})$. 


\subsection{Efeitos da deriva genética na variabilidade fenotipica das subpopulações.}

Foram avaliados três caracteres quantitativos(produção de grãos por planta - PG (g/pl), altura da planta - AP (cm/pl) e altura da espiga-AE $(\mathrm{cm} / \mathrm{pl})$ nas 10 subpopulações da primeira e segunda geração de amostragem ( $G_{1}$ e $G_{2}$, respectivamente).e de cada uma das populações de origem (BR-105 e BR-106). As médias, assim, como a amplitude de variação da população de origem e das subpopulações e a porcentagem da amplitude de variação das subpopulações em relação a amplitude de variação da população de origem dos três caracteres avaliados estão apresentados nas Tabelas de 16 a 21.

Para o caráter PG (Tabela 16), observou-se uma considerável variação entre as subpopulações com relação as amplitudes e entre essas e a amplitude da população BR-105 (290 g/pl) que variaram de 87,93\% (255 g/pl subpopulação 1) a 134,48\% (390 g/pl - subpopulação 10) em $\mathrm{G}_{1}$ e $77,58 \%$ (225 $\mathrm{g} / \mathrm{pl}$ - subpopulação 1) a 120,69\% (350 g/pl - subpopulação 4) em $\mathrm{G}_{2}$. E para a população BR-106 (Tabela 17) esta variação foi de 92,21\% (284 g/pl subpopulação 10) a 146,75\% (452 g/pl - subpopulação 1) em $\mathrm{G}_{1}$ e de $74,02 \%$ (220 g/pl - subpopulação 2) a 150,97\% (465 g/pl - subpopulação 7)) para $\mathrm{G}_{2}$.

Com relação ao caráter AP (Tabelas 18 ), os valores observados de variação entre as amplitudes das subpopulações, e entre essas e a amplitude da população BR-105, variaram de $84,21 \%$ (80 cm/pl - sub-pop 5, 6, 8 e 9) a 121,05\% (115 cm/pl - subpopulação 2 e 4) para $G_{1}$ e de 73,68\% (70 $\mathrm{cm} / \mathrm{pl}$ - subpopulação 6 e 7) a 142,10\% (135 cm/pl - subpopulação 5) para $\mathrm{G}_{2}$.

$\mathrm{Na}$ Tabela 19, são apresentadas valores das amplitudes de variação das subpopulações, para o caráter $A P$, e entre essas e a amplitude da população BR-106 variando de 150,00\% (120 cm/pl - subpopulação 1 e 6) a $81,25 \%\left(65 \mathrm{~cm} / \mathrm{pl}\right.$ - subpopulação 5) para $G_{1}$. Para $G_{2}$ a variação foi de 
$200,00 \%(160 \mathrm{~cm} / \mathrm{pl}$ - subpopulação 9) a $87,50 \%(70 \mathrm{~cm} / \mathrm{pl}$ - subpopulação 3) entre as subpopulações em relação a amplitude da população BR-106.

A variação das subpopulações em relação a população BR-105 para o caráter $A E$ (Tabela 20), foi de $92,86 \%(65 \mathrm{~cm} / \mathrm{pl}$ - subpopulações 5 e 7) a $128,57 \%$ (90 cm/pl - subpopulação 2 e 6) em $\mathrm{G}_{1}$, e $71,43 \%(50 \mathrm{~cm} / \mathrm{pl}$ subpopulação 6) a $135,71 \%\left(95 \mathrm{~cm} / \mathrm{pl}\right.$ - subpopulação 4) em $\mathrm{G}_{2}$. Para a população BR-106 variação das subpopulações em relação a amplitude da população BR-106 variou de $85,71 \%(60 \mathrm{~cm} / \mathrm{pl}$ - subpopulação $5,6,7$ e 9) a $128,57 \%\left(90 \mathrm{~cm} / \mathrm{pl}\right.$ - subpopulação 4) em $\mathrm{G}_{1}$, e $71,43 \%(50 \mathrm{~cm} / \mathrm{pl}$ subpopulação 3) a $114,29 \%\left(80 \mathrm{~cm} / \mathrm{pl}\right.$ - subpopulação 2) em $\mathrm{G}_{2}$.

Nas duas situações, tanto para as subpopulações da população BR-105 ou BR-106, quanto para $G_{1}$ ou $G_{2}$, para os três caracteres incluem-se variações superiores e inferiores aos valores obtidos da população de origem $e$ de maneira geral houve uma diminuição da amplitude de variação nas subpopulações em $G_{2}$ quando comparados as respectivas subpopulações em $\mathrm{G}_{1}$ para o mesmo caráter. Isto é esperado, pois a deriva genética reduz a variabilidade genética dentro das subpopulações.

A comparação entre duas variâncias fenotípicas foram testadas com o interesse de saber se uma amostra não difere significamente de outra, isto é, se duas amostras podem ser consideradas como extraídas de uma mesma população. De acordo com a Vencovsky \& Barriga, (1992) pode-se decompor a variância fenotípica em: $\sigma_{F_{p o p}}^{2}=\sigma_{G_{p o p}}^{2}+\sigma_{E p o p}^{2}$, onde:

$\sigma_{F_{p o p}}^{2}=$ variância fenotípica da população de origem;

$\sigma_{G_{p o p}}^{2}=$ variância genética da população de origem e, $\sigma_{E_{p o p}}^{2}=$ Variância ambiental da população.

Assim como:

$\sigma_{F_{\text {subpop }}}^{2}=\sigma_{G_{\text {subpop }}}^{2}+\sigma_{\text {Esubpop }}^{2}$, 
$\sigma_{F_{\text {sbbop }}}^{2}=$ variância fenotípica da subpopulação em qualquer geração;

$\sigma_{G_{\text {subpop }}}^{2}=$ variância genética da subpopulação em qualquer geração,

$\sigma_{E_{\text {suboop }}}^{2}=$ Variância ambiental da subpopulação.

A comparação entre a variância fenotípica da população e a variância fenotípica da subpopulação será:

$\frac{\sigma_{F_{p o p}}^{2}}{\sigma_{F_{\text {subopp }}}^{2}}=\frac{\sigma_{G_{p o p}}^{2}+\sigma_{E_{p o p}}^{2}}{\sigma_{G_{\text {stbopp }}}^{2}+\sigma_{E_{\text {subopp }}}^{2}}$

mas, como os tratamentos foram avaliados no mesmo delineamento experimental e ambientes, as variâncias ambientais podem ser consideradas similares, isto é;

$\sigma_{E_{\text {pop }}}^{2}=\sigma_{E_{\text {subpop }}}^{2}$,

então, pode-se dizer que quando é feita a comparação das variâncias fenotípicas entre a população de origem com as subpopulações das duas gerações de amostragem está se comparando na realidade as variâncias genéticas, pois:

$\frac{\sigma_{F_{p o p}}^{2}}{\sigma_{F_{\text {stopop }}}^{2}}=\frac{\sigma_{G_{p o p}}^{2}+\sigma_{E}^{2}}{\sigma_{G_{\text {sopopp }}}^{2}+\sigma_{E}^{2}}$.

Este mesmo raciocínio pode ser feito quando se compara as variâncias fenotípicas entre as respectivas subpopulações nas duas gerações de amostragem, pois, está se comparando as respectivas variâncias genéticas entre as duas gerações de amostragem.

As Tabelas 22, 23 e 24 apresenta os valores das comparações pelo teste $F$ das variâncias fenotípicas das subpopulações nas duas gerações 
de amostragem entre si $\left(G_{1} / G_{2}\right.$ ou $\left.G_{2} / G_{1}\right)$, entre a população de origem com as gerações $G_{1}$ e $G_{2}$ (pop/G ou G/pop) para os três caracteres $P G, A P$ e AE. Para a população BR-105, observa-se, para as variâncias fenotípicas entre as gerações, que as subpopulações 2, 3 e 10 diferem para o caráter PG, as subpopulações 5, 6, 7 e 10 para o caráter AP e as subpopulações 6 e 8 para o caráter AE. Para a população BR-106, as variâncias fenotípicas das subpopulações 1, 2, 5, 6 e 8 diferem para o caráter PG, as subpopulações 1, 4, 5, 8, 9 e 10 diferem para o caráter AP e as subpopulações 1, 2, 4, e 9 diferem para o caráter AE. De modo geral, as subpopulações da população BR-106 diferem mais entre as gerações com relação as variâncias fenotípicas que a população BR-105.

Quando comparamos a população de origem com as respectivas subpopulações nas duas gerações, observou-se que para a população BR-105 e para o caráter PG, as variâncias fenotípicas diferem da população de origem para as subpopulações 2,7 e $10 \mathrm{em} \mathrm{G}_{1}$ e a subpopulação 4 difere em relação a $\mathrm{G}_{2}$. As subpopulações 5,6 e 10 diferem para o caráter $A P$ em relação a $G_{2}$ e as subpopulações 4 e 6 diferem para o caráter $A E$ em $G_{1}$ e $G_{2}$.

Para a população BR-106, as variâncias fenotípicas das subpopulações para o caráter $P G$ em $G_{1}$ diferem em relação a população de origem para as subpopulações $2,7 \mathrm{em} \mathrm{G}_{1}$ e as subpopulações $1,4,6$ e 8 diferem em $G_{2}$. As subpopulações $1,4,6$, e 8 diferem em $G_{1}$ e as subpopulações 6 e 9 diferem em $G_{2}$ para o caráter AP. A subpopulação 4 difere para o caráter $A E$ em $G_{1}$ e a subpopulação 3 difere em $G_{2}$.

Outra observação com relação a estes dados diz respeito a comparação entre as variâncias fenotípicas entre as gerações de amostragem. Observa-se nas Tabelas 22, 23 e 24 que as variâncias fenotípicas das subpopulações diminuem na geração $G_{2}$, isto é, são menores que na geração $\mathrm{G}_{1}$, para todos os caracteres principalmente para a população $B R-106$, onde na maioria das subpopulações houve diminuição das variâncias fenotípicas. Isto é uma das consequências da deriva genética, pois resulta na perda de variação 
genética dentro das subpopulações, há uma redução geral dos heterozigotos e uma divergência entre as subpopulações (Futuyma, 1992). Observa-se que é possivel obter subpopulações que diferem da população de origem com apenas uma geração de amostragem, bastando apenas que esta amostragem seja muito reduzida em relação a representação genética . Segundo Falconer \& Mackay (1996) a medida que ocorre deriva genética, a variação entre as subpopulações aumenta geração a geração até que a população de origem seja descaracterizada.

Um maior número de subpopulações diferentes em $G_{1}$ e $G_{2}$ e em relação a população de origem foi observado para a população BR-106, podendo ser evidenciado que esta população sofreu mais com os efeitos da deriva genética. Esses resultados em geral, podem ter ocorrido em função das duas populações possuirem origem e estruturas genéticas diferentes (Naspolini Filho, et al., 1981; Souza Junior et al., 1993; Lanza et al., 1997). E a variância fenotipica pode ser considerada similar, em algumas subpopulações uma vez que houve diminuição da variância genética devido a uniformidade genética dependendo do alelo que torna comum ou mais frequente em cada uma das subpopulações, inteiramente ao acaso.

Outro aspecto analisado refere-se a distribuição de freqüências dos valores observados das populações de origem (BR-105 e BR-106) e das subpopulações nas duas gerações de amostragens (Figuras 1 a 18). Para os caracteres peso de grãos por planta, altura de planta e altura de espiga, o teste estatístico para normalidade dos dados e os coeficientes de assimetria e curtose não apresentaram significância para a grande maioria das subpopulações das populações BR-105 e BR-106 (Tabelas 25, 26 e 27). Isso indica que, para essas características, o p rocesso de amostragem de tamanho reduzido $(\mathrm{Ne}=5)$, que leva a alterações de freqüências alélicas, se deu sem que houvesse perda de normalidade e presença de assimetrias ou curtose na distribuição dos dados. 
Os valores de $\mathrm{W}$ que foram significativos indicam que os dados não se ajustam à distribuição normal. Para o caráter peso de grãos, isso ocorreu para a subpopulações $1,2,3,9$ e 10 na $G_{2}$ da população BR-105, e para a população BR-106 foram significativos para as subpopulações 1 e 10 na $G_{1}$ e 8 na $G 2$ e a própria população BR-106. A população BR-105 e as subpopulações 3 e 4 na $G_{1}$ também não se ajustaram à distribuição normal para o caráter $A P$ assim como a subpopulação 1 da geração $G_{1}$ da população $B R-106$. Para $A E$ apenas a subpopulação 10 , em $G_{1}$, da população $B R-105$ e subpopulação 1 e $8\left(G_{1}\right)$ da população BR-106 não se ajustaram à normalidade.

Com relação aos coeficientes de assimetria dos dados pode-se concluir que a distribuição dos dados para os três caracteres em todas as situações são simétricos .

Com a análise da curtose observa-se que as subpopulações 2 e 9 na geração $G_{1}$ da população $B R-105$ e as subpopulações 1 e 9 em $G_{2}$ da população BR-106 para o caráter peso de grãos por planta; as subpopulações $7\left(G_{1}\right)$ e $9\left(G_{2}\right)$ para altura da planta da população $\mathrm{Br}-105$; a subpopulação 9 $\left(G_{2}\right)$ da população BR-106 para altura de espiga são leptocúrtica, significando que uma maior concentração dos valores estão próximos da média. Todas estas informações de valores máximos e mínimos, normalidades dos dados assimetria, curtose e a propria distribuição das médias podem ser visualizados nas Figuras de 1 a 18. 


\subsection{Considerações finais}

Existem poucos relatos na literatura sobre os efeitos da deriva genética em vegetais, especialmente aqueles envolvendo caracteres quantitativos. Desses relatos as estimativas da deriva genética estão confundidas com efeitos da seleção e provavelmente não refletem os reais efeitos da deriva genética. Baseado nessas informações avaliou-se duas populações geneticamente diferentes, com relação aos efeitos da deriva genética em caracteres quantitativos, isoladamente de efeitos da seleção.

A partir dos dados obtidos, foram realizadas as análises de variâncias e teste de médias para auxiliar na avaliação dos efeitos da deriva genética das populações e respectivas subpopulações em duas gerações de amostragem. Os resultados significativos da análise conjunta revelam que a estratégia utilizada para obtenção das subpopulações de tamanho efetivo $\mathrm{Ne}=5$, foi coerente e efetiva para detectar efeitos da deriva genética. A precisão experimental obtida nos experimentos pode ser considerada como sendo adequada para todos os caracteres avaliados, em comparação aos padrões apresentados na literatura. Graças a estes resultados foi possivel avaliar com mais detalhes os efeitos da deriva genética nestas duas populações e respectivas subpopulações.

As médias avaliadas, utilizando o teste de Tukey, evidencia diferenças entre as médias para a maioria dos caracteres das subpopulações da população BR-105, nas duas geraçiōes. Obteve-se médias superiores e inferiores a população de origem e no geral, a amplitude de variação aumentou de $G_{1}$ para $G_{2}$ para os caracteres $P$ e PRO e diminuiu para os caracteres AP e $A E$ e r. Em relação a população BR-106 comportamento diferenciado foi observado, as subpopulaçōes não diferenciaram com relação ao carater $P$ e PRO na primeira geração de amostragem e o caráter $P$ obteve médias apenas inferiores a população de origem. Pouca diferenciação foi observada no 
restante dos caracteres nas gerações de amostragens e a amplitude de variação teve um aumento da primeira geração em relação a segunda geração para todos os caracteres, exceto para o caráter $r$ onde a amplitude foi igual nas duas gerações. A tendência das médias das subpopulações da população BR106 foram de diminuir em $G_{2}$ em relação a população de origem e em $G_{1}$. Isto, quando comparado a menor tendência de diminuição das médias das subpopulações da população BR-105, exceto para os carateres $A E$ e $r$ onde não houve diferenças com relação as tendências. Essas diferenças podem sugerir que existe diferenciação com relação aos efeitos da deriva genética para populações com estruturas geneticas distintas.

Os contrastes para avaliar os efeitos da deriva genética das gerações de amostragem $\left(G_{1}\right.$ e $\left.G_{2}\right)$ em relação a população de origem demonstram que o caráter produção de grãos por ha, caráter de grande importância, foi o que mais detectou efeitos significativos da deriva genética para as populações BR-105 e BR-106, assim como o contraste da média geral das subpopulações em relação as gerações de amostragem. Isto se deve a complexidade desse caráter e ao maior nivel de dominância fazendo com que sofra mais os efeitos da deriva genética e da depressão por endogamia. Nas população BR-105 e BR-106 ocorreram aumentos e dimuições dos valores dos caracteres em função dos efeitos da deriva genética, exceto para o caráter $P$ na população BR-106. Nos caracteres menos complexos e com maior nível de efeitos aditivos foram detectados pouca influência dos efeitos da deriva genética como verificado para os caracteres PRO e $r$ e os efeitos observados para os caracteres $A P$ e $A E$ os efeitos da deriva genética foram menos expressivos que para o caráter $P$. E em função dos dados da literatura e as observações avaliadas pode inferir que a magnitude da deriva genética dos caracteres foi função de modificações nas freqüências de alelos de efeito de dominância. Comprovando portanto, a sua importância e fazendo-se indispensável a sua consideração em amostras de tamanho reduzido.

Pode-se observar que os efeitos da deriva genética são 
totalmente imprevisiveis com relação a direção e a sua magnitude. Observaram efeitos cumulativos, redução ou aumento do caráter, assim como, redução ou aumento na primeira geração e o inverso na segunda geração.

Os efeitos foram mais pronunciados quando é realizado o contraste entre as gerações e a população de origem do que nos contrastes entre as gerações. Isto deve ter ocorrido em função do tamanho da amostra, que da população de origem para as gerações de amostragens, o tamanho efetivo é igual a 5 , porém partindo de uma população grande. Já entre as gerações o tamanho efetivo é igual a cinco, no entanto partindo de uma população muito pequena $(\mathrm{Ne}=5)$. O efeito da depressão por endogamia estará presente em função da presença da carga genética e da redução dos heterozigotos.

As populações BR-105 e BR-106 tiveram comportamentos diferentes com relação aos efeitos da deriva genética e isto se deve ao fato da população BR-106 ser um composto enquanto que a população BR-105 é é considerada um sintético,pois foi submetida a três ciclos de seleção recorrente com progênies $S_{1}$ e com intensidade de seleção de $1 \%$. Assim, pode se deduzir que a estrutura genética da população interfere nos efeitos da deriva genética.

Os efeitos da deriva genética na variabilidade fenotípica das subpopulações mostra que algumas subpopulações diferem da população de origem apenas com uma ou duas gerações de amostragens e também ocorre diferenciação das subpopulações entre as duas gerações sucessivas de amostragens em função da descaracterização genética da população de origem devido a deriva genética. Essa diferenciação das subpopulações é esperada em função da amostragem de tamanho reduzido $(\mathrm{Ne}=5)$, sendo uma conseqüência da deriva genética.

Com base nos objetivos inicialmente proposto neste trabalho e nos resultados obtidos, a avaliação dos efeitos da deriva genética, em amostras de tamanhos efetivos reduzidos, é muito importante para a manutenção de coleções de bancos de germoplasma e para programas de 
melhoramento genético, onde o tamanho da amostra pode descaracterizar a população de origem. Em coletas de germoplasma as pequenas amostras não representaram as populações de origem pois alguns genótipos podem não ser amostrados e, consequentemente, alguns alelos podem ser perdidos durante 0 processo amostral, principalmente aqueles cujas freqüências são baixas. Durante a manutenção dessas coleções de germoplasmas essas amostras de tamanho reduzido serão descaracterizadas perdendo a variabilidade genética. E o problema se agrava principalmente para os alelos considerados raros. Com relação aos programas de melhoramento genético, a deriva genética pode limitar os ganhos genéticos, pois os efeitos da deriva genética podem estar confundidos com os efeitos da seleção.

A deriva genética em decorrência do tamanho efetivo reduzido é função das alterações das freqüências alélicas e tem como conseqüências a diferenciação entre subpopulações, redução da variabilidade genética dentro da subpopulação, levando a uniformidade genética. $E$ a última conseqüência é o aumento na freqüência de homozigiotos, às custas de um decréscimo de heterozigotos que conjugada com a tendência geral dos alelos deletérios serem recessivos é a base genética da depressão por endogamia.

Ao avaliar os efeitos da deriva genética em caracteres quantitativos nas populações BR-105 e BR-106 foram observadas diferenciação entre as subpopulações e redução da variabilidade genética podendo-se inferir que as populações estudadas sofreram os efeitos da deriva genética devido o tamanho reduzido da amostra em função das alterações das freqüências alélicas. Neste sentido acredita-se que a avaliação realizada foi adequada. 


\section{CONCLUSÕES}

a) Os efeitos da deriva genética, ocorridos em função da amostragem de tamanho reduzido, foram significativos para a maioria dos caracteres quantitativos avaliados nas duas populações.

b) As populações BR-105 e BR-106 apresentaram comportamentos diferentes quanto aos efeitos da deriva genética, o que pode ser explicado pelo fato de essas populações terem estruturas genéticas diferentes.

c) O caráter produção de grãos foi mais afetado pela deriva genética que os demais caracteres, o gue pode ser devido ao fato de esse caráter ter nivel de dominância superior aos dos demais caracteres avaliados.

d) Os efeitos da deriva genética foram imprevisiveis com relação à direção e a magnitude, o que está de acordo com a teoria dos processos aleatórios de amostragem.

e) A variabilidade genética das subpopulações foi significativamente afetada pela deriva genética, embora as distribuições de freqüências dos caracteres tenham se mantido normal e mantido as suas simetrias e curtoses 
f) A deriva genética afetou significativamente o comportamento e a variabilidade fenotípica das subpopulações nas duas gerações de amostragem, distanciando-as das suas populações de origem. Assim, na coleta e manutenção de bancos de germoplasmas e nos programas de melhoramento os efeitos da deriva genética devem ser considerados para manter a integridade genética das populações e não limitar os programas de melhoramento genético. 


\section{REFERÊNCIAS BIBLIOGRÁEICAS}

ALLARD, R. W. Principios do melhoramento genético das plantas. São Paulo: Edgard Blücher, 1971. 381p.

BEIGUELMAN, B. Curso prático de bioestatística. 2ed. Ribeirão Preto: Sociedade Brasileira de Genética, 1991. 224p.

BREWBAKER, J. L. Genética na agricultura. Trad. de J.T.A. Gurgel e R. Vencovsky. São Paulo: Polígono; EDUSP, 1969. 224p.

BURI, P. Gene frequency drift in small population of mutant Drosophila. Evolution, v.10, p.367-402, 1956.

CORRALES BLANDÓN, $S$. Efeito da deriva genética sobre caracteres quantitativos em uma população de milho (Zeea mays L.). Piracicaba, 1996, 90p. Tese (Doutorado) - Escola Superior de Agricultura "Luiz de Queiroz Universidade de São Paulo.

CABALLERO, A. Developments in the prediction of effective population size. Heredity, v. 73, p. 657-679, 1994.

CAIN, A. J. ; SHEPPARD, P. M. Natural selection in Cepaea. Genetics, v.39, p.89-116, Jan. 1954. 
CROW, J.F. Breeding structures of populations. II. Effective population number. In: KEMPTHORNE, O; BANCROFT, T.A; GOWEN, J.W.; LUSH, J. L. Statistics and mathematics in biology. Ames: lowa State College Press, 1954. p 543-556.

CROW, J. F. ; KIMURA, M. An introduction to population genetics theory. New York: Harper ; Row, 1970. 591p

DIAS, C. T. S. Estatística básica através do SAS para Windows. Piracicaba: ESALQ, 1995. 138p.

DOBZHANSKY, T. H. ; PAVLOVSKY, O. An experimental study of interaction between genetic drift and natural selection. Evolution, v.11, p.311-319, Sept. 1957.

EYHERABIDE, G.H; HALUAUER, R. Reciprocal full-sib recurrent selection in maize: II. Contributions of additive, dominance, and genetic drift effects. Crop Science, v.31, p. 1442-1448, Nov./Dec. 1991.

FALCONER, D. S; MACKAY, T.F. Introduction to quantitative genetics. 4.ed. Harlow: Longman Scientific, 1996. 464p.

FORD, E. B. The genetics of polimorphism in the Lepidoptera. Advances in Genetics, v.5, p.43-87, 1953.

FUTUYMA, D. J. Estrutura populacional e deriva genética. In: VIVO, M. de; SENE, F. (Coord.) Biologia evolutiva. Ribeirão Preto: Sociedade Brasileira de Genética; CNPg, 1992. cap. 5, p127-157.

GALE, J.S. ; LAWRENCE, M.J. The decay of variability. In: HOLDEM, ; WILLIAMS, Crop genetic resources: conservation and evaluation. Local: Editora, 1994. 
GOMES, F.P. Curso de estatística experimental. 13. ed. São Paulo: Nobel, 1990. 403p.

HALLAUER , A. R.; MIRANDA FILHO, J. B. Quantitative genetics in maize breeding. Ames: lowa State University Press, 1988. 468p.

HEMS, T.C.; HALLAUER, A.R.; SMITH 2 O.S. Genetic drift and selection evaluated from recurrent selection programs in maize. Crop Science, v.29, p.602-607, May-June1989.

KEERATINIJAKAL, V.; LAMKEY, K.R. Genetic effects associated with reciprocal recurrent selection in BSSS and BSCB1 maize populations. Crop Science, v.33, p78-82, Jan./Feb. 1993.

KERR, W.E. ; WRIGHT, S. Experimental studies of the distribution of gene frequencies in very small populations of Drosophila melanogaster : I. Forked. Evolution, v. 8, p.172-177,1954a.

KERR, W.E. ; WRIGHT, S. Experimental studies of the distribution of gene frequencies in very small populations of Drosophila melanogaster : III. aristapedia and spineless. Evolution, v.8, p. 293-302, 1954b.

KIMURA, M. Process leading to guase-fixation of genes in natural populations due to random fluctuation of selection intensities. Genetics, v. 39, p.280295, Sept. 1954.

KIMURA, M. Solution of a process of random genetic drift with a continuos model. Proceedings of the National Academy of Sciences of the USA, v.41, p.144-50, Feb. 1955.

LAMOTTE, M. Recherches sur la structure génétique des populations naturelles de Cepaea nemoralis (L.). Bulletin of Biology, v. 35,p.238, 1951. 
LANDI, P. ; FRASCAROLI, E. Responses to four cycles of full-sib family recurrent selection in an F2 maize population. Maydica, v.38, p.31-37, 1993.

LANZA, L.L.B.; SOUZA JR.C.L.; OTTOBONI,L.M.M.; VIEIRA, M.L.C.;SOUZA,A.P. Genetic distance of inbred line and prediction of maize single-cross performance using RAPD markers. Theoretical and Applied Genetics, v.94, p.1023-1030, 1997.

MAYR, E. Animal species and evolution. Cambridge: Harvard University Press, 1963.

METTLER, L.E. ; GREGG, T.G. Genética de populações e evolução. São Paulo: Polígono, 1973. 262p.

NASPOLINI FILHO, V; GAMA, E. E. G.; VIANNA, R.T.; MORO, J.R. General and specific combining ability for yield in a diallel among 18 maize (Zea mays L.) populations. Revista Brasileira de Genética, v.4, p.571-577, 1981.

NEI, M.; MARUYAMA T. ; CHAKRABORTY. The bottleneck effect and genetic variability in populations. Evolution, v.29, p.1-10, 1975.

NOGUEIRA, M.C.S. Estatística experimental aplicada à experimentação agronômica. Piracicaba:ESALQ, 1994. 247p.

OYERVIDES-GARCIA, M.; HALLAUER, A.R. Selection-induced differences among strain of lowa Stiff Stalk synthetic maize. Crop science, v.26, p.506-511, 1986.

PATERNIANI, M. E. A. G. Z. Efeitos da redução do tamanho de populações de milho (Zea mays L.). Piracicaba, 1995. 117p. Tese (Doutorado) - Escola Superior de Agricultura "Luiz de Queiroz", Universidade de São Paulo. 
REZENDE, G. D. S. P. Heterose, depressão por endogamia e variabilidade genética associadas à seleção e oscilação genética nas populações de milho BR-105 e BR-106. Piracicaba, 1997. 112p. Tese (Doutorado) - Escola Superior de Agricultura "Luiz de Queiroz", Universidade de São Paulo.

ROBERTSON, A. The effect of inbreeding on the variation due to recessive genes. Genetics, v.37, p.189-207, Mar. 1952.

SMITH, O.S. A model for evaluting progress from recurrent selection. Crop Science, v.19, p.223-225, Mar./Apr. 1979a.

SMITH, O.S. Application of a modified diallel analysis to evaluate recurrent selection for grain yield in maize. Crop Science, v.19, p.819-822, Nov./Dec. 1979b.

SMITH, O.S. Evaluation of recurrent selection in BSSS, BSCB1, and BS13 maize populations. Crop Science, v.23, p.35-40, Jan./Feb. 1983

SOKAL, R.R. ; ROHF, F.J. Biometry: the principle and practice of statistic in biological research. Freeman \& Co., 1981. 859p.

SOUZA Jr., C.L. Manutenção de coleções de bancos de germoplasma. Piracicaba: ESALQ, 1995. 28p.

SOUZA Jr., C.L.; SANTOS, M. X.; MAGNAVACA, R. ; GAMA, E. E. G. Estimativas de parâmetros genéticos na interpopulação de milho BR-105 $x$ BR-106 e suas implicações no melhoramento. Pesquisa Agropecuária Brasileira, v.28, p. 473-479, 1993.

STOJŠ IN, D.; KANNENBERG, W. Genetic. changes associated with diferrent methods of recurrent selection in five maize populations: II. Indirectly selected traits. Crop Science, v. 34, p. 1473-1479, Nov:/Dec. 1994. 
TRAGESSER, S.L.; YOUNGQUIST, W.C.; SMITH, O.S.; COMPTON, W.A. Drift vs. selection effects from five recurrent selection programs in maize. Maydica, v.34, p. 23-32, 1989.

VENCOVSKY, R. Herança quantitativa. In: PATERNIANI, E.; VIEGAS, G.P. Melhoramento e produção do milho. Campinas: Fundação Cargill, 1987. cap. 5 , p137-209.

VENCOVSKY, R. ; BARRIGA, P. Genética biométrica no fitomelhoramento. Ribeirão Preto: Sociedade Brasileira de Genética, 1992. 496p.

WRIGHT, S. Evolution in Mendelian populations. Genetics, v.16, p.97-159, 1931.

WRIGHT, S. ; KERR, W. E. Experimental studies of the distribution of gene frequencies in very small populations of Drosophila melanogaster: II. bar. Evolution, v.8, p. 225-240, 1954. 


\section{TABELAS}


Tabela 04 -Análise de variância realizada para os caracteres produção de grãos $(P)$, altura da planta (AP), altura da espiga ( $A E)$, prolificidade (PRO) e posição relativa da espiga na planta (r). CNPsoja (1º época de plantio), Londrina, PR, 1996/97.

\begin{tabular}{|c|c|c|c|c|c|c|}
\hline \multirow[b]{2}{*}{ FV } & \multirow[b]{2}{*}{ GL } & \multicolumn{5}{|c|}{ QM } \\
\hline & & $\underset{\text { (ton/ha) }}{\mathrm{P}}$ & $\underset{(\mathrm{cm} / \mathrm{pl})^{2}}{A P}$ & $\underset{(\mathrm{cm} / \mathrm{p} \mid)^{2}}{\mathrm{AE}}$ & $\begin{array}{c}\mathrm{PRO}^{+} \\
(\mathrm{es} p / p \mid)^{2}\end{array}$ & $\begin{array}{c}r^{+} \\
(A E / A P)^{2}\end{array}$ \\
\hline Blocos & 7 & 0,70 & $309,02^{*}$ & 112,36 & $1,79^{*}$ & $0,29^{\star \star}$ \\
\hline Tratamentos & 48 & $3,28^{\star \star}$ & $671,02^{\star \star}$ & $471,28^{\star \star}$ & $1,92^{\star \star}$ & $0,16^{\star \star}$ \\
\hline Erro & 336 & 1,28 & 126,41 & 82,65 & 0,67 & 0,04 \\
\hline C. V. (\%) & & $\uparrow \uparrow, 89$ & 4,34 & 5,78 & 8,49 & 3,16 \\
\hline
\end{tabular}

* , **: Significativo ao nível de $5 \%$ e $1 \%$ de probabilidade, respectivamente.

+: Quadrados médios multiplicados por $10^{2}$. 
Tabela 05 - Análise de variância realizada para os caracteres produção de grãos $(P)$, altura da planta $(A P)$, altura da espiga $(A E)$, prolificidade (PRO) e posição relativa da espiga na planta (r). CNPsoja (2을 época de plantio), Londrina, PR, 1996/97.

\begin{tabular}{|c|c|c|c|c|c|c|}
\hline \multirow[b]{2}{*}{ FV } & \multirow[b]{2}{*}{ GL } & \multicolumn{5}{|c|}{ QM } \\
\hline & & $\begin{array}{c}\mathrm{P} \\
\text { (ton/ha) }\end{array}$ & $\begin{array}{c}\text { AP } \\
(\mathrm{cm} / \mathrm{pl})^{2}\end{array}$ & $\underset{(\mathrm{cm} / \mathrm{pl})^{2}}{\mathrm{AE}}$ & $\begin{array}{c}\mathrm{PRO}^{+} \\
\text {(esp/pl| })^{2}\end{array}$ & $\begin{array}{c}r^{+} \\
(\mathrm{AE} / \mathrm{AP})^{2}\end{array}$ \\
\hline Blocos & 7 & 12,5 & $475,45^{\star}$ & $280,33^{\star}$ & $11,6 \uparrow^{\star \star}$ & 0,09 \\
\hline Tratamentos & 48 & $4,27^{\star \star}$ & $531,72^{\star *}$ & $376,37^{\star \star}$ & $2,05^{\star \star}$ & $0,22^{\star *}$ \\
\hline Erro & 336 & 1,41 & 211,29 & 131,39 & 0,94 & 0,05 \\
\hline C V. (\%) & & 13,99 & 6,38 & 8,73 & 9,85 & 4,03 \\
\hline
\end{tabular}

${ }^{*},{ }^{* *}$ : Significativo ao nível de $5 \%$ e $1 \%$ de probabilidade, respectivamente.

+ : Quadrados médios multiplicados por $10^{2}$. 
Tabela 06 - Análise de variância realizada para os caracteres produção de grãos $(P)$, altura da planta $(A P)$, altura da espiga $(A E)$, prolificidade (PRO) e posição relativa da espiga na planta $(r)$. Caterpillar $\left(1^{\circ}\right.$ época de plantio), Piracicaba, SP, 1996/97.

\begin{tabular}{|c|c|c|c|c|c|c|}
\hline \multirow[b]{2}{*}{ FV } & \multirow[b]{2}{*}{ GL } & \multicolumn{5}{|c|}{ QM } \\
\hline & & $\underset{(\text { ton } / \mathrm{ha})^{2}}{\mathrm{P}}$ & $\underset{(\mathrm{cm} / \mathrm{pl})^{2}}{\mathrm{AP}}$ & $\underset{(\mathrm{cm} / \mathrm{pl})^{2}}{\mathrm{AE}}$ & $\begin{array}{c}\mathrm{PRO}^{+} \\
\text {(esp/pl) }\end{array}$ & $\begin{array}{c}r^{+} \\
(A E / A P)^{2}\end{array}$ \\
\hline Blocos & 7 & 1,62 & $1203,72^{\star *}$ & $137,70^{* *}$ & $20,79^{\star \star}$ & $1,35^{\star \star}$ \\
\hline Tratamentos & 48 & $7,32^{\star \star}$ & $720,86^{\star \star}$ & $265,55^{\star \star}$ & $1,24^{*}$ & $0,08^{\star \star}$ \\
\hline Erro & 336 & 0,82 & 85,69 & 38,76 & 0,79 & 0,04 \\
\hline C V. (\%) & & 11,35 & 4,29 & 5,10 & 10,33 & 3,64 \\
\hline
\end{tabular}

* , **: Significativo ao nível de $5 \%$ e $1 \%$ de probabilidade, respectivamente.

+: Quadrados médios multiplicados por $10^{2}$. 
Tabela 07 - Análise de variância realizada para os caracteres produção de grãos $(P)$, altura da planta (AP), altura da espiga (AE), prolificidade (PRO) e posição relativa da espiga na planta $(r)$. Caterpillar $\left(2^{\circ}\right.$ época de plantio), Piracicaba, SP, 1996/97.

\begin{tabular}{|c|c|c|c|c|c|c|}
\hline \multirow[b]{2}{*}{ FV } & \multirow[b]{2}{*}{ GL } & \multicolumn{5}{|c|}{ QM } \\
\hline & & $\begin{array}{c}P \\
\text { (ton/ha) }\end{array}$ & $\begin{array}{c}A P \\
(\mathrm{~cm} / \mathrm{pl})^{2}\end{array}$ & $\underset{(\mathrm{cm} / \mathrm{pl})^{2}}{\mathrm{AE}}$ & $\begin{array}{c}\mathrm{PRO}^{+} \\
\text {(esp/pl| })^{2}\end{array}$ & $\begin{array}{c}r^{+} \\
(\mathrm{AE} / \mathrm{AP})^{2}\end{array}$ \\
\hline Blocos & 7 & 4,93 & $1450,48^{* \pi}$ & 82,99 & $15,67^{\star \star}$ & $1,18^{\star *}$ \\
\hline Tratamentos & 48 & $6,44^{\star \star}$ & $530,86^{\star \star}$ & $226,92^{\star \star}$ & $3,12^{\star \star}$ & $0,14^{\star \star}$ \\
\hline Erro & 336 & 0,77 & 177,91 & $280,70^{* *}$ & 0,94 & 0,05 \\
\hline C V. (\%) & & 12,64 & 6,68 & 7,99 & 11,59 & 3,94 \\
\hline
\end{tabular}

* , **: Significativo ao nivel de $5 \%$ e $\uparrow \%$ de probabilidade, respectivamente.

+: Quadrados médios multiplicados por $10^{2}$. 
Tabela 08 - Análise de variância realizada para os caracteres produção de grãos $(P)$, altura da planta $(A P)$, altura da espiga $(A E)$, prolificidade (PRO) e posição relativa da espiga na planta (r). Departamento de Genética ESALQ/USP , Piracicaba, SP, 1996/97.

\begin{tabular}{|c|c|c|c|c|c|c|}
\hline \multirow[b]{2}{*}{ FV } & \multirow[b]{2}{*}{ GL } & \multicolumn{5}{|c|}{ QM } \\
\hline & & $\begin{array}{c}\mathrm{P} \\
\text { (ton } / \mathrm{ha})^{2}\end{array}$ & $\begin{array}{c}\mathrm{AP} \\
(\mathrm{cm} / \mathrm{pl})^{2}\end{array}$ & $\begin{array}{c}\mathrm{AE} \\
(\mathrm{cm} / \mathrm{pl})^{2}\end{array}$ & $\begin{array}{c}\mathrm{PRO}^{+} \\
\text {(esp/pl) }\end{array}$ & $\begin{array}{c}r^{+} \\
(\mathrm{AE} / \mathrm{AP})^{2}\end{array}$ \\
\hline Blocos & 7 & $2,84^{* t}$ & $2076,28 \pi$ & $1523,92^{\star \star}$ & $22,87^{\star \star}$ & $1,11^{\text {** }}$ \\
\hline Tratamentos & 48 & $7,54^{\star *}$ & $753,69^{\star \star}$ & $467,09^{\star \star}$ & $2,68^{\star \star}$ & $0,25^{\star \star}$ \\
\hline Erro & 336 & 0,98 & 201,77 & 96,19 & 1,03 & 0,07 \\
\hline C V. (\%) & & 13,86 & 6,73 & 8,21 & 12,24 & 4,61 \\
\hline
\end{tabular}

${ }^{*},{ }^{\star \star}$ : Significativo ao nível de $5 \%$ e $\uparrow \%$ de probabilidade, respectivamente.

+ : Quadrados médios multiplicados por $10^{2}$. 
Tabela 09 - Valores dos quadrados médios e significância das análises de variância conjuntas de cinco ambientes realizadas para os caracteres produção de grãos (P), altura da planta (AP), altura da espiga ( $A E)$, prolificidade ( $P R O)$ e posição relativa da espiga na planta (r), avaliados nas populações BR-105 e BR-106 e nas respectivas subpopulações nas gerações $G_{1}$ e $G_{2}$ de amostragem de tamanho efetivo restrito.

\begin{tabular}{|c|c|c|c|c|c|c|}
\hline \multirow[b]{2}{*}{ FV } & \multirow[b]{2}{*}{ GL } & \multicolumn{5}{|c|}{ QM } \\
\hline & & $\mathrm{P}(\text { ton } / \mathrm{ha})^{2}$ & $\operatorname{AP}(c m / p P)^{2}$ & $\mathrm{AE}(\mathrm{cm} / \mathrm{pl})^{2}$ & $\mathrm{PRO}^{+}(\mathrm{esp} / \mathrm{pl})^{2}$ & $r^{+}(A E / A P)^{2}$ \\
\hline Locais (L) & 4 & $434,49^{\star \star}$ & 200319,99 *t. & $\uparrow 14664,29^{\star \star}$ & $206,87^{\star \star}$ & $11,80^{\star \star}$ \\
\hline Blocos ( Locais) & 35 & $4,52^{\star \star}$ & $1102,99^{\star \star}$ & $456,24^{\star \star}$ & $14,55^{\star \star}$ & $0,80^{\star \star}$ \\
\hline Tratamentos $(T)$ & 48 & $18,71^{\star \star}$ & $2376,35^{\star \star}$ & $1387,15^{\star \star}$ & $5,01^{\star \star}$ & $0,54^{\star \star}$ \\
\hline BR-105 - $G_{1}$ & 9 & $7,14^{\star \star}$ & $2147,57^{\star \star}$ & $1137,47^{\star \star}$ & $5,80^{\star \star}$ & $0,21^{\star \star}$ \\
\hline BR-105 - $G_{2}$ & 9 & $8,32^{\star \star *}$ & $1487,33^{\text {** }}$ & $1015,40^{\star \star \star}$ & $5,23^{\star \star}$ & $0,26^{\star \star}$ \\
\hline BR-105 vs $G_{1}$ e $G_{2}$ & 1 & 9,05 & 229,97 & $114,97^{\star \star}$ & 2,62 & 0,01 \\
\hline$B R-105 G_{1}$ vs $B R-105 G_{2}$ & 1 & 1,58 & 19,86 & $459,60^{*}$ & 2,15 & $0,71^{\star \star}$ \\
\hline BR-106 - $G_{1}$ & 9 & $4,83^{\star}$ & $1006,74^{\star \star}$ & $360,00^{\star \star}$ & $2,87^{\star}$ & $0,18^{\star \star}$ \\
\hline BR-106 - $G_{2}$ & 9 & $9,18^{\star \star}$ & $1970,79^{*}$ & $818,74^{\star \star}$ & $7,14^{\star \star}$ & $0,49^{\star \star}$ \\
\hline BR-106 vs $G_{1}$ e $G_{2}$ & 1 & $24,47^{\star \star}$ & 9,27 & 4,21 & 3,42 & 0,01 \\
\hline$B R-106 G_{1}$ vs $B R-106 G_{2}$ & 1 & 8,32 & $1966,37^{\star \star}$ & $1099,16^{\star \star}$ & 0,35 & 0,11 \\
\hline Outros & 8 & $72,82^{\star \star}$ & $6537,63^{\star \star}$ & $4365,10^{\star \star}$ & $5,32^{\star \star}$ & $1,86^{\star \star}$ \\
\hline Tratamentos X Locais & 192 & $2,53^{\star \star}$ & $208,05^{\star \star}$ & $118,49^{\star \star}$ & 1,50 ** & $0,08^{\star \star}$ \\
\hline Erro médio & 1680 & 1,05 & 160,61 & 86,40 & 0,88 & 0,05 \\
\hline C V. (\%) & & 12,80 & 5,69 & 7,22 & 10,45 & 3,89 \\
\hline
\end{tabular}

* , **: Significativo ao nivel de $5 \%$ e $1 \%$ de probabilidade, respectivamente,

+ : Quadrados médios multiplicados por $10^{2}$, 
Tabela 10 -Médias gerais dos caracteres produção de grãos $(P)$, altura da planta (AP), altura da espiga ( $A E$ ), posição relativa da espiga (r) e prolificidade (PRO), avaliados na população BR-105 e nas 10 subpopulações da primeira geração $\left(G_{1}\right)$ e 10 sub-populações da segunda geração $\left(\mathrm{G}_{2}\right)$ de amostragem de tamanho efetivo restrito.

\begin{tabular}{|c|c|c|c|c|c|}
\hline & $P$ (ton/ha) & AP (cm/pl) & $\mathrm{AE}(\mathrm{cm} / \mathrm{pl})$ & PRO (esp/pl) & $r$ (AE/AP) \\
\hline BR-105 & 7,94 & 226,15 & 132,52 & 0,91 & 0,58 \\
\hline \multicolumn{6}{|l|}{$\mathbf{G}_{1}$} \\
\hline Subpop 01 & 7,46 & 211,67 & 123,12 & 0,88 & 0,58 \\
\hline Subpop 02 & 7,27 & 223,67 & 133,17 & 0,89 & 0,59 \\
\hline Subpop 03 & 6,66 & 228,10 & 133,89 & 0,81 & 0,59 \\
\hline Subpop 04 & 7,99 & 237,03 & 140,02 & 0,91 & 0,59 \\
\hline Subpop 05 & 7,85 & 226,44 & 132,21 & 0,93 & 0,58 \\
\hline Subpop 06 & 7,73 & 229,37 & 135,52 & 0,89 & 0,59 \\
\hline Subpop 07 & 7,37 & 227,19 & 135,87 & 0,92 & 0,60 \\
\hline Subpop 08 & 7,15 & 217,42 & 126,40 & 0,87 & 0,58 \\
\hline Subpop 09 & 6,91 & 217,77 & 125,08 & 0,82 & 0,57 \\
\hline Subpop 10 & 7,66 & 219,79 & 130,11 & 0,88 & 0,59 \\
\hline \multicolumn{6}{|l|}{$G_{2}$} \\
\hline Subpop 01 & 7,72 & 215,69 & 124,29 & 0,89 & 0,57 \\
\hline Subpop 02 & 8,02 & 222,77 & 127,92 & 0,92 & 0,57 \\
\hline Subpop 03 & 6,44 & 230,44 & 135,11 & 0,82 & 0,59 \\
\hline Subpop 04 & 7,76 & 234,80 & 139,84 & 0,89 & 0,59 \\
\hline Subpop 05 & 7,21 & 223,44 & 131,28 & 0,91 & 0,59 \\
\hline Subpop 06 & 7,16 & 225,89 & 132,37 & 0,87 & 0,58 \\
\hline Subpop 07 & 7,62 & 225,70 & 131,43 & 0,89 & 0,58 \\
\hline Subpop 08 & 7,57 & 219,29 & 127,94 & 0,89 & 0,58 \\
\hline Subpop 09 & 7,57 & 215,34 & 123,35 & 0,89 & 0,57 \\
\hline Subpop 10 & 7,87 & 221,95 & 126,71 & 0,96 & 0,57 \\
\hline
\end{tabular}


Tabela 11 -Médias gerais dos caracteres produção de grãos $(P)$, altura da planta (AP), altura da espiga ( $A E$ ), posição relativa da espiga ( $r$ ) e prolificidade (PRO), avaliados na população BR-106, nas 10 subpopulações da primeira geração $\left(G_{1}\right)$ e 10 sub-populações da segunda geração $\left(\mathrm{G}_{2}\right)$ de amostragem de tamanho efetivo restrito.

\begin{tabular}{|c|c|c|c|c|c|}
\hline & $P$ (ton/ha) & AP (cm/pl) & $\mathrm{AE}(\mathrm{cm} / \mathrm{pl})$ & PRO (esp/pl ) & $r(A E / A P)$ \\
\hline BR-106 & 9,11 & 224,08 & 129,18 & 0,93 & 0,57 \\
\hline \multicolumn{6}{|l|}{$\mathbf{G}_{1}$} \\
\hline Subpop 01 & 8,30 & 224,71 & 128,65 & 0,87 & 0,57 \\
\hline Subpop 02 & 8,92 & 232,51 & 136,02 & 0,88 & 0,58 \\
\hline Subpop 03 & 8,70 & 221,39 & 127,65 & 0,87 & 0,58 \\
\hline Subpop 04 & 7,91 & 222,88 & 131,80 & 0,88 & 0,59 \\
\hline Subpop 05 & 8,55 & 221,62 & 127,38 & 0,94 & 0,57 \\
\hline Subpop 06 & 8,29 & 228,89 & 132,43 & 0,93 & 0,58 \\
\hline Subpop-07 & 8,86 & 234,92 & 134,76 & 0,92 & 0,57 \\
\hline Subpop 08 & 8,47 & 222,68 & 129,44 & 0,90 & 0,58 \\
\hline Subpop 09 & 8,02 & 221,81 & 128,29 & 0,90 & 0,58 \\
\hline Subpop10 & 8,11 & 230,00 & 130,40 & 0,86 & 0,56 \\
\hline \multicolumn{6}{|l|}{$G_{2}$} \\
\hline Subpop 01 & 8,49 & 225,65 & 128,45 & 0,88 & 0,57 \\
\hline Subpop 02 & 8,59 & 232,38 & 137,07 & 0,86 & 0,59 \\
\hline Subpop 03 & 8,72 & 211,34 & 124,66 & 0,90 & 0,59 \\
\hline Subpop 04 & 8,16 & 228,06 & 134,23 & 0,89 & 0,59 \\
\hline Subpop 05 & 8,13 & 218,23 & 123,84 & 0,93 & 0,56 \\
\hline Subpop 06 & 7,69 & 221,27 & 126,70 & 0,93 & 0,57 \\
\hline Subpop 07 & 9,02 & 231,81 & 130,42 & 0,99 & 0,56 \\
\hline Subpop 08 & 7,97 & 220,67 & 128,61 & 0,88 & 0,58 \\
\hline Subpop 09 & 7,64 & 214,82 & 122,97 & 0,89 & 0,57 \\
\hline Subpop 10 & 7,70 & 225,85 & 126,43 & 0,84 & 0,56 \\
\hline
\end{tabular}

DMS (5\%): P (1,14 ton/ha); AP (10,32 cm/pl); AE (7,79cm/pl); PRO (0,09 esp/pl); $r$ (0,02 AE/AP) . 

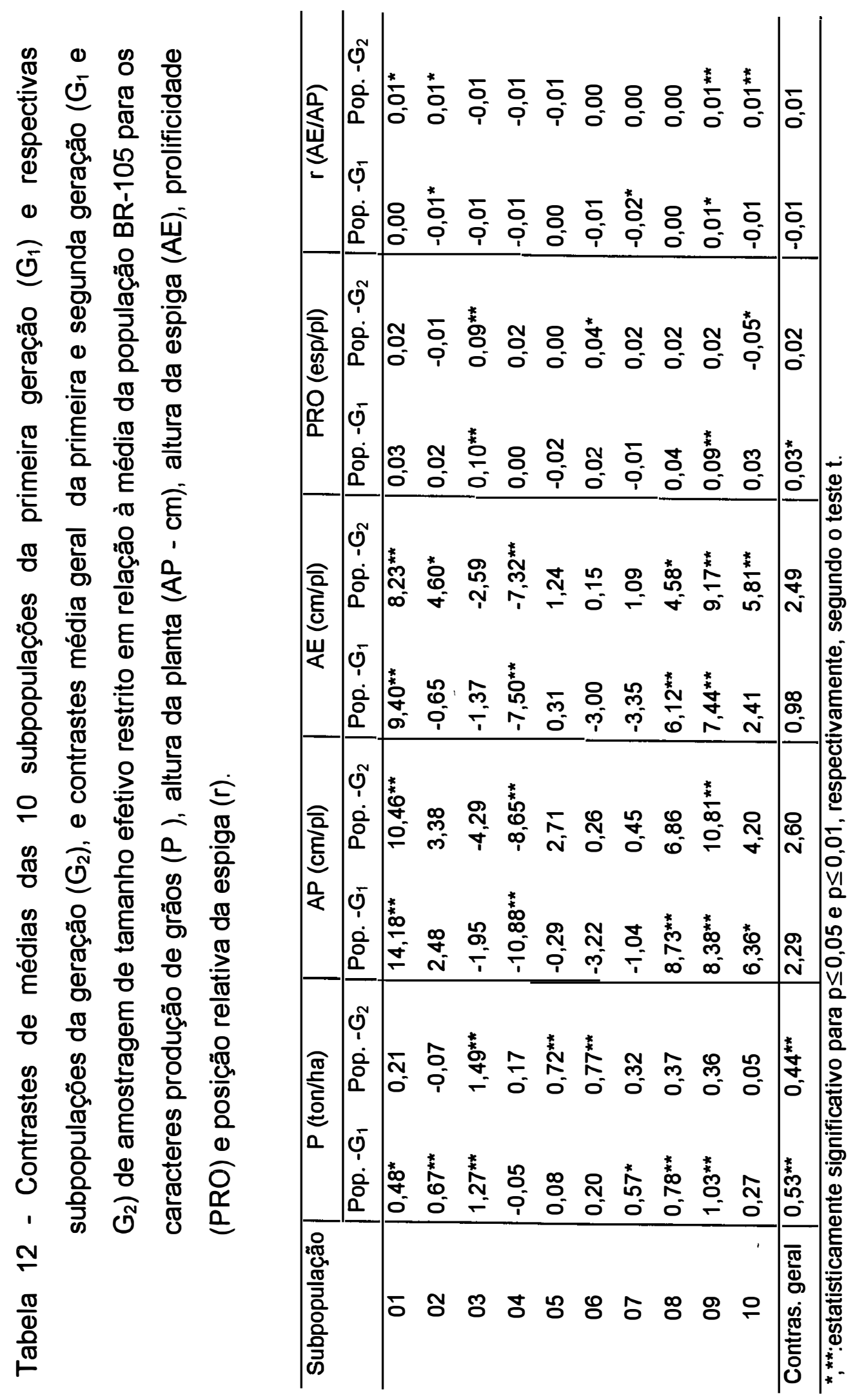


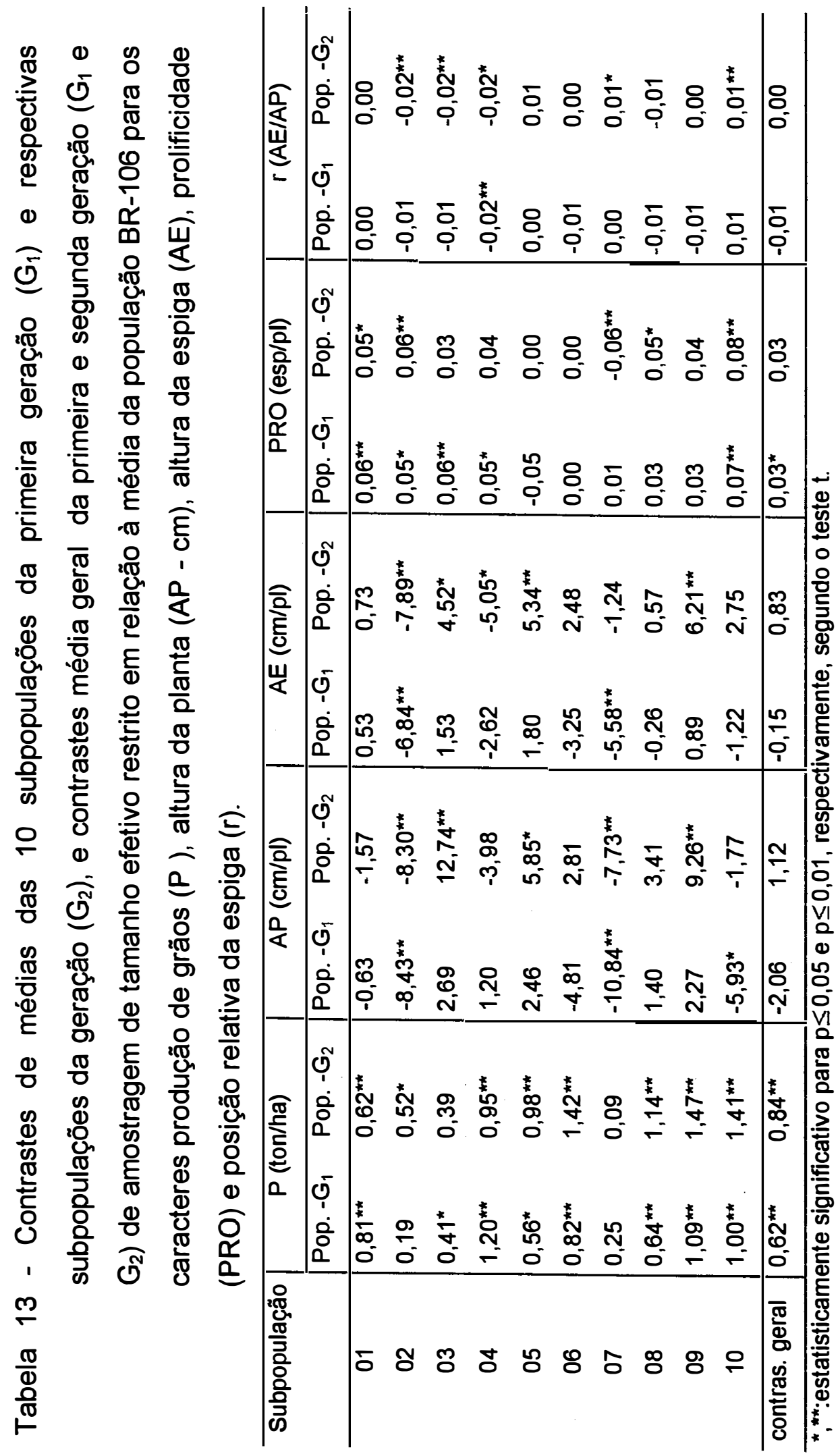


Tabela 14 -Contrastes de médias das 10 subpopulações da primeira geração $\left(G_{1}\right)$ em relação as média das respectivas subpopulações da segunda geração $\left(G_{2}\right)$, e contraste da média geral entre as gerações $G_{1}$ e $G_{2}$ de amostragem de tamanho efetivo restrito da população BR-105 para os caracteres produção de grãos $(P)$, altura da planta (AP), altura da espiga (AE), prolificidade (PRO) e posição relativa da espiga $(r)$.

\begin{tabular}{|c|c|c|c|c|c|}
\hline & $\mathrm{P}$ (ton/ha) & AP $(\mathrm{cm} / \mathrm{pl})$ & $\overline{A E}(\mathrm{~cm} / \mathrm{pl})$ & PRO (esp/pl) & $r(\mathrm{AE} / \mathrm{AP})$ \\
\hline Subpopulação. & $G_{1}-G_{2}$ & $G_{1}-G_{2}$ & $G_{1}-G_{2}$ & $G_{1}-G_{2}$ & $G_{1}-G_{2}$ \\
\hline 01 & $-0,26$ & $-0,42$ & $-1,17$ & $-0,01$ & 0,01 \\
\hline 02 & $-0,75^{\star \star}$ & 0,90 & $5,25^{*}$ & $-0,03$ & $0,02^{\star \star}$ \\
\hline 03 & 0,22 & $-2,34$ & $-1,22$ & $-0,01$ & 0,00 \\
\hline 04 & 0,23 & $2,23^{-}$ & 0,18 & 0,02 & 0,00 \\
\hline 05 & $0,64^{\star \star}$ & 2,99 & 0,93 & 0,02 & 0,01 \\
\hline 06 & $0,57^{*}$ & $3 ; 48$ & 3,15 & 0,02 & 0,01 \\
\hline 07 & $-0,25$ & $.1,49$ & $4,44^{*}$ & 0,03 & $0,02^{\star *}$ \\
\hline 08 & $-0,42$ & $-1,87$ & $-1,54$ & $-0,02$ & 0,00 \\
\hline 09 & $-0,66^{\star \star}$ & 2,43 & $\uparrow, 73$ & $-0,07^{\star \star}$ & 0,00 \\
\hline 10 & $-0,21$ & $-2,16-$ & 3,40 & $-0,08^{\star \star}$ & $0,02^{\star \star}$ \\
\hline contras.geral & $-0,08$ & 0,30 & $1,52^{*}$ & $-0,01$ & $-0,01^{\star \star}$ \\
\hline
\end{tabular}

${ }^{*},{ }^{\star \star *}$ :estatisticamente significativo para $p \leq 0,05$ e $p \leq 0,01$, respectivamente, segundo o teste $t$. 
Tabela 15 - Contrastes de médias das 10 subpopulações da primeira geração $\left(G_{1}\right)$ em relação as média das respectivas subpopulações da segunda geração $\left(G_{2}\right)$, e contraste da média geral entre as gerações $G_{1}$ e $G_{2}$ de amostragem de tamanho efetivo restrito da população BR-106 para os caracteres produção de grãos $(P)$, altura da planta (AP), altura da espiga (AE), prolificidade $(P R O)$ e posição relativa da espiga ( $r$ ).

\begin{tabular}{c|l|l|l|l|l}
\hline \multirow{2}{*}{ Subpopulação. } & $P$ (ton/ha) & $A P(\mathrm{~cm} / \mathrm{pl})$ & $A E(\mathrm{~cm} / \mathrm{pl})$ & $P R O(\mathrm{esp} / \mathrm{pl})$ & $\mathrm{r}(\mathrm{AE} / \mathrm{AP})$ \\
\cline { 2 - 6 } & $\mathrm{G}_{1}-\mathrm{G}_{2}$ & $\mathrm{G}_{1}-\mathrm{G}_{2}$ & $\mathrm{G}_{1}-\mathrm{G}_{2}$ & $\mathrm{G}_{1}-\mathrm{G}_{2}$ & $\mathrm{G}_{1}-\mathrm{G}_{2}$ \\
\hline 01 & $-0,18$ & $-0,94$ & 0,19 & $-0,01$ & 0,00 \\
02 & 0,33 & 0,15 & 1,04 & 0,02 & $-0,01$ \\
03 & $-0,03$ & $10,05^{\star \star}$ & 2,98 & $-0,03$ & $-0,01^{\star}$ \\
04 & $-0,25$ & $-5,18$ & 2,43 & $-0,01$ & 0,00 \\
05 & 0,42 & 3,39 & 3,54 & 0,01 & 0,01 \\
06 & $0,59^{\star \star}$ & $7,62^{\star \star}$ & $5,73^{\star \star}$ & 0,00 & 0,01 \\
07 & $-0,16$ & 3,11 & $4,33^{\star}$ & $-0,07^{\star \star}$ & $0,01^{\star}$ \\
08 & $0,49^{\star}$ & 2,01 & 0,83 & 0,02 & 0,00 \\
09 & 0,37 & $6,99^{\star}$ & $5,32^{\star \star}$ & 0,01 & 0,01 \\
10 & 0,40 & 4,16 & 3,97 & 0,01 & 0,00 \\
\hline contras.geral & 0,22 & $3,18^{\star *}$ & $-2,37^{\star \star}$ & $-0,01$ & 0,01 \\
\hline
\end{tabular}


Tabela 16 -Valores da média, máximo, mínimo e amplitude de variação e \% da amplitude de variação em relação a amplitude de variação da população BR-105 obtidos de uma amostra de 120 plantas das populações BR-105, das 10 subpopulações da primeira geração $\left(G_{1}\right)$ e respectivas subpopulações da segunda geração $\left(G_{2}\right)$ de amostragem de tamanho efetivo reduzido, para o caráter peso de grãos por planta $(\mathrm{g} / \mathrm{pl})$.

\begin{tabular}{|c|c|c|c|c|c|}
\hline $\begin{array}{c}\text { Geração- } \\
\text { sub-população }\end{array}$ & Média & Máximo- & Mínimo & amplitude. & $\begin{array}{c}\text { amplitude } \\
(\%)\end{array}$ \\
\hline BR-105 & 139,40 & 3001 & 10 & 290 & (N) \\
\hline Sub-pop 01-G & 146,73 & 295 & 40 & 255 & 87,93 \\
\hline Sub-pop 01-G $G_{2}$ & 142,48 & 265 & 40 & 225 & 77,59 \\
\hline $\begin{array}{l}\text { subpop } 02 \mathrm{G} \\
\text { subjopopors }\end{array}$ & 146,36 & $\begin{array}{l}395 \\
296\end{array}$ & 20 & 355 & 1224 \\
\hline Sub-pop 03-G 1 & 140,25 & 340 & 26 & 314 & 108,27 \\
\hline Sub-pop 03-G $G_{2}$ & 125,44 & 285 & 22 & 263 & 90,69 \\
\hline 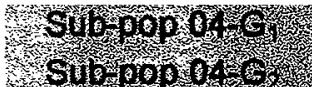 & 14898 & $\frac{340}{360}$ & 40 & 300 & 40345 \\
\hline Sub-pop $05-G_{1}$ & 139,03 & 290 & 32 & 258 & 88,96 \\
\hline Sub-pop 05-G $G_{2}$ & 140,88 & 345 & 26 & 319 & 110,00 \\
\hline 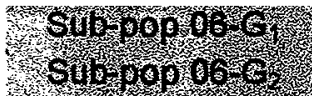 & 14678 & $\begin{array}{l}330 \\
295\end{array}$ & 80 & 201 & 9656 \\
\hline Sub-pop 07-G & 143,18 & 340 & 24 & 316 & 108,96 \\
\hline Sub-pop $07-G_{2}$ & 141,45 & 350 & 30 & 320 & 110,34 \\
\hline Sibpop ob & 1807 & 326. & 15 & 315 & 105. \\
\hline Sub gor $08 \mathrm{c}$ & 13489 & 300 & 15 & 285 & 9828 \\
\hline Sub-pop 09-G & 134,70 & 350 & 16 & 334 & 115,17 \\
\hline Sub-pop 09-G & 132,50 & 280 & 32 & 248 & 85.51 \\
\hline Sub 10001001 & 414,40 & 420 & & 367 & 134,168 \\
\hline & & & & & \\
\hline
\end{tabular}


Tabela 17 - Valores da média, máximo , mínimo e amplitude de variação e \% da amplitude de variação em relação a amplitude de variação da população BR-106 obtidos de uma amostra de 120 plantas das populações BR-106, das 10 subpopulações da primeira geração $\left(G_{1}\right)$ e respectivas subpopulações da segunda geração $\left(G_{2}\right)$ de amostragem de tamanho efetivo reduzido, para o caráter peso de grãos por planta $(\mathrm{g} / \mathrm{pl})$.

\begin{tabular}{|c|c|c|c|c|c|}
\hline $\begin{array}{c}\text { Geração - } \\
\text { sub-população }\end{array}$ & Média & Máximo_ & Mínimo & amplitude & $\begin{array}{c}\text { amplitude } \\
(\%)\end{array}$ \\
\hline BR 106 & 16843 & 350 & 42 & 308 & W \\
\hline Sub-pop 01-G 1 & 160,57 & 360 & 20 & 340 & 110,39 \\
\hline Sub-pop 01-G & 164,58 & 485 & 20 & 465 & 150,97 \\
\hline subpop $02 \mathrm{G}$ & $\begin{array}{l}16957 \\
18135\end{array}$ & $\begin{array}{l}410 \\
340\end{array}$ & 16 & 394 & 12792 \\
\hline Sub-pop 03-G & 167.62 & 385 & 25 & 360 & 116,88 \\
\hline Sub-pop 03-G & 164,23 & 340 & 30 & 310 & 100.65 \\
\hline 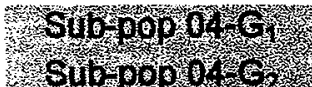 & 16025 & 405 & 40: & 365 & $1 / 8,15$ \\
\hline Sub-pop 05-G & 167,44 & 425 & 16 & 409 & 132,79 \\
\hline Sub-pop 05-G ${ }_{2}$ & 153,99 & 300 & 25 & 275 & 89,29 \\
\hline 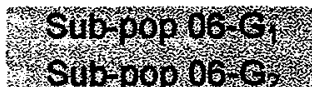 & $\begin{array}{l}14978 \\
5336\end{array}$ & 395 & 20 & W15 & 10221 \\
\hline Sub-pop 07-G & 176,57 & 470 & 18 & 452 & 146,75 \\
\hline Sub-pop $07-G_{2}$ & 162,50 & 350 & 35 & 315 & 102,27 \\
\hline siberosose & 166,2 & 370 & 45 & 325 & 10552 \\
\hline Sut pop od 6 & 14692 & 265 & 74 & 251 & 81.49 \\
\hline Sub-pop 09-G ${ }_{1}$ & 150,10 & 345 & 20 & 325 & 105,52 \\
\hline Sub-pop 09-G & 152,69 & 406 & 30 & 376 & 122,08 \\
\hline 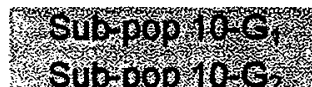 & 15679 & 300 & 16 & 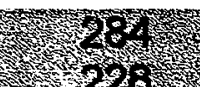 & 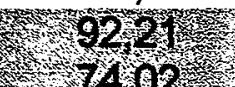 \\
\hline
\end{tabular}


Tabela 18 -Valores da média, máximo , mínimo e amplitude de variação e \% da amplitude de variação em relaçāo a amplitude de variação da população BR-105 obtidos de uma amostra de 120 plantas das populações BR-105, das 10 subpopulações da primeira geração $\left(G_{1}\right)$ e respectivas subpopulações da segunda geração $\left(G_{2}\right)$ de amostragem de tamanho efetivo reduzido, para o caráter altura da planta $(\mathrm{cm} / \mathrm{pl})$.

\begin{tabular}{|c|c|c|c|c|c|}
\hline $\begin{array}{c}\text { Geração - } \\
\text { subpopulação }\end{array}$ & Média & Maximo & Mínimo & amplitude & $\begin{array}{c}\text { amplitude } \\
(\%)\end{array}$ \\
\hline BR-1@5 & 218 & 270 & 175 & 95 & 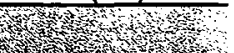 \\
\hline Sub-pop 01-G & 206 & 240 & 150 & 90 & 94,74 \\
\hline Sub-pop 01-G & 205 & 240 & 160 & 80 & 84,21 \\
\hline Subpop 02 G & 215 & 280 & 165 & 115 & 12105 \\
\hline Sub pop 026 & 214 & 245 & 155 & 90 & 9474 \\
\hline Sub-pop 03-G & 218 & 270 & 170 & 100 & 105,26 \\
\hline Sub-pop 03-G $G_{2}$ & 219 & 265 & 180 & 85 & 89,47 \\
\hline Sub pop $04 \mathrm{G}$ & 223 & 280 & 165 & 115 & 12105 \\
\hline Sub $00004 \mathrm{C}_{2}$ & 223 & 260 & 160 & 100 & 105,26 \\
\hline Sub-pop 05-G & 213 & 250 & 170 & 80 & 84,21 \\
\hline Sub-pop 05-G & 211 & 285 & 150 & 135 & 142,10 \\
\hline Sutpop $06 \mathrm{~s}$ & 216 & 255. & 175 & 800 & 84,21 \\
\hline sub pop 0e, & 215 & 250 & 180 & 70 & 73,68 \\
\hline Sub-pop 07-G & 213 & 245 & 135 & 110 & 115,79 \\
\hline Sub-pop 07-G $G_{2}$ & 217 & 250 & 180 & 70 & 73,68 \\
\hline Sub pop 08 G & 212 & 259 & 170 & 80 & $64 / 21$ \\
\hline Sub popog $G$ ? & 208 & 250 & 160 & 90 & 9474 \\
\hline Sub-pop 09-G 1 & 209 & 250 & 170 & 80 & 84,21 \\
\hline Sub-pop $09-G_{2}$ & 203 & 240 & 130 & 110 & 115,79 \\
\hline $\begin{array}{l}\text { Subpop } 10 G \\
\text { sub pop } 10, G_{2}\end{array}$ & 210 & $\begin{array}{l}250 \\
265\end{array}$ & 165 & 85 & $8,9,47$ \\
\hline
\end{tabular}


Tabela 19 - Valores da média, máximo , mínimo e amplitude de variação e \% da amplitude de variação em relação a amplitude de variação da população BR-106 obtidos de uma amostra de 120 plantas das populaçōes BR-106, das 10 subpopulações da primeira geração $\left(G_{1}\right)$ e respectivas subpopulações da segunda geração $\left(G_{2}\right)$ de amostragem de tamanho efetivo reduzido, para o caráter altura da planta $(\mathrm{cm} / \mathrm{pl})$.

\begin{tabular}{|c|c|c|c|c|c|}
\hline $\begin{array}{c}\text { Geração - } \\
\text { subpopulação }\end{array}$ & Média & Máxima & Mínimo & amplitude & $\begin{array}{c}\text { amplitude } \\
(\%)\end{array}$ \\
\hline BR 106 & 212 & 250 & 170 & 80 & $4 x$ \\
\hline Sub-pop 01-G & 210 & 270 & 150 & 20 & 150,00 \\
\hline Sub-pop 01-G & 217 & 255 & 180 & 75 & 93,75 \\
\hline Subpoo $02 G$ & 224 & 275 & 150 & 115 & 14375 \\
\hline 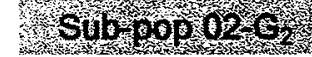 & 221 & 260 & 185 & 75 & 93,75 \\
\hline Sub-pop 03-G & 211 & 245 & 170 & 75 & 93,75 \\
\hline Sub-pop 03-G $G_{2}$ & 205 & 240 & 170 & 70 & 87,50 \\
\hline Sul gop of $\mathrm{G}_{1}$ & 211 & 260 & 150 & 110 & 137,50 \\
\hline - & 249 & 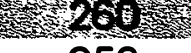 & 180 & 80 & 10000 \\
\hline Sub-pop 05-G & 214 & 250 & 185 & 65 & 81,25 \\
\hline Sub-pop 05-G & 212 & 260 & 170 & 90 & 112,50 \\
\hline Sul $p 0006$ & 219 & 270 & 150 & 120 & 15000 \\
\hline Sibjog o6 & 209 & 260 & 150 & 110 & 137.50 \\
\hline Sub-pop 07-G & 224 & 260 & 180 & 80 & 100,00 \\
\hline Sub-pop 07-G & 223 & 290 & 190 & 100 & 125,00 \\
\hline 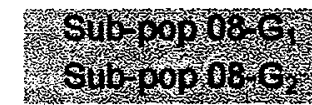 & 214 & 260 & 160 & 100 & 12500 \\
\hline Sub-pop 09-G & 212 & 245 & 170 & 75 & 93,75 \\
\hline Sub-pop 09-G & 204 & 290 & 130 & 160 & 200,00 \\
\hline 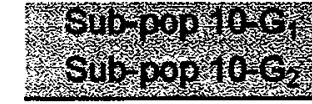 & & 260 & 175 & r15 & $\begin{array}{l}14375 \\
93,75\end{array}$ \\
\hline
\end{tabular}


Tabela 20 - Valores da média, máximo , mínimo e amplitude de variação e \% da amplitude de variação em relação a amplitude de variação da população BR-105 obtidos de uma amostra de 120 plantas das populações BR-105, das 10 subpopulações da primeira geração $\left(G_{1}\right)$ e respectivas subpopulações da segunda geração $\left(G_{2}\right)$ de amostragem de tamanho efetivo reduzido, para o caráter altura da espiga (cm/pl).

\begin{tabular}{|c|c|c|c|c|c|}
\hline $\begin{array}{c}\text { Geração - } \\
\text { subpopulação }\end{array}$ & Média & Máxima & Mínimo & amplitude & $\begin{array}{c}\text { amplitude } \\
(\%)\end{array}$ \\
\hline BR-105 & 122 & 160 & 90 & $70^{\circ}$ & reventy \\
\hline Sub-pop 01-G & 117 & 160 & 80 & 80 & 114,28 \\
\hline Sub-pop 01-G & 115 & 140 & 80 & 60 & 85,71 \\
\hline $\begin{array}{l}\text { Sulopor } 02 \mathrm{c} \\
\text { sub pop } 02 \mathrm{e}\end{array}$ & $1 x^{12}$ & 160 & $\begin{array}{r}70 \\
80\end{array}$ & (190. & $\begin{array}{l}128,57 \\
92,86\end{array}$ \\
\hline Sub-pop 03-G & 125 & 170 & 90 & 80 & 114,29 \\
\hline Sub-pop $03-G_{2}$ & 123 & 175 & 90 & 85 & 121,43 \\
\hline Sub ero 196 & $\begin{array}{r}128 \\
130\end{array}$ & $\begin{array}{l}1700 \\
190\end{array}$ & $\begin{array}{l}85 \\
95\end{array}$ & 85 & 121,43 \\
\hline Sub-pop 05-G $G_{1}$ & 121 & 155 & 90 & 65 & 92,86 \\
\hline Sub-pop 05-G & 118 & 155 & 90 & 65 & 92,86 \\
\hline $\begin{array}{l}\text { Suppop } 06-6 \\
\text { Subpop } 06-6\end{array}$ & -125 & $\begin{array}{r}175 \\
450\end{array}$ & 85 & $\begin{array}{l}90 \\
50\end{array}$ & $\begin{array}{r}128,57 \\
71,43\end{array}$ \\
\hline Sub-pop 07-G $G_{1}$ & 123 & 170 & 105 & 65 & 92,86 \\
\hline Sub-pop $07-G_{2}$ & 124 & 165 & 95 & 70 & 100,00 \\
\hline Sulvoposes & 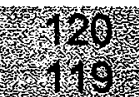 & 170 & 85 & 85 & 124.46 \\
\hline Sub-pop 09-G $G_{1}$ & 117 & 160 & 80 & 80 & 114,29 \\
\hline Sub-pop 09-G ${ }_{2}$ & 112 & 140 & 50 & 90 & 128,57 \\
\hline subpop 106 & 120 & 155 & 85 & $\begin{array}{r}70 \\
\times 80\end{array}$ & $(100,00$ \\
\hline
\end{tabular}


Tabela 21 - Valores da média, máximo , mínimo e amplitude de variação e \% da amplitude de variação em relação a amplitude de variação da população BR-106 obtidos de uma amostra de 120 plantas das populações $B R-106$, das 10 subpopulações da primeira geração $\left(G_{1}\right)$ e respectivas subpopulações da segunda geração $\left(G_{2}\right)$ de amostragem de tamanho efetivo reduzido, para o caráter altura da espiga (cm/pl).

\begin{tabular}{|c|c|c|c|c|c|}
\hline $\begin{array}{c}\text { Geração - } \\
\text { subpopulação }\end{array}$ & Média & Máximo & Mínimo & amplitude & $\begin{array}{c}\text { amplitude } \\
(\%)\end{array}$ \\
\hline BR-106 & $117 \%$ & 1553 & 85 & 70 & 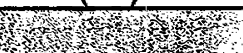 \\
\hline Sub-pop 01-G & 116 & 160 & 75 & 85 & 121,43 \\
\hline Sub-pop 01-G & 119 & 150 & 85 & 65 & 92,86 \\
\hline sub pop $02 \mathrm{G}$ & 129 & 185 & 100 & 85 & 12148 \\
\hline Surpopo2 G & 126 & 175 & 95 & 80 & 114,29 \\
\hline Sub-pop 03-G & 118 & 150 & 85 & 65 & 92,86 \\
\hline Sub-pop 03-G $G_{2}$ & 116 & 140 & 90 & 50 & 71,73 \\
\hline Subpop 04, G & 120 & 165 & $\pi$ & 90 & 128,57 \\
\hline SLibpopotse & 126 & 160 & 95 & & 9286 \\
\hline Sub-pop 05-G & 119 & 150 & 90 & 60 & 85,71 \\
\hline Sub-pop 05-G $G_{2}$ & 118 & 155 & 90 & 65 & 92,86 \\
\hline Sub popos & 122 & 150 & 90. & 60 & 8571 \\
\hline Sub-pop 07-G & 127 & 160 & 100 & 60 & 85,71 \\
\hline Sub-pop 07-G & 123 & 165 & 95 & 70 & 100,00 \\
\hline 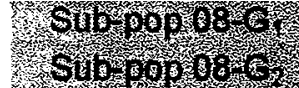 & 1218 & 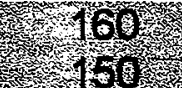 & 80 & $\frac{80}{20}$ & 10429 \\
\hline Sub-pop 09-G ${ }_{1}$ & 119 & 150 & 90 & 60 & 85,71 \\
\hline Sub-pop 09-G $G_{2}$ & 115 & 145 & 70 & 75 & 107,14 \\
\hline Sulupop of & 123 & 150 & 86 & 76 & 100.00 \\
\hline
\end{tabular}


Tabela 22 -Valores da variância fenotípica $\left(\hat{\sigma}_{F}^{2}\right)$, teste $F$ entre as respectivas variâncias da primeira geração $\left(G_{1}\right)$ e segunda geração $\left(G_{2}\right)$ das subpopulações e teste $F$ entre a população e as geraçãos $G_{1}$ e $G_{2}$ de amostragem de tamanho efetivo reduzido, obtidos de uma amostra de 120 plantas das populações BR-105 e BR-106 para o caráter peso de grãos por planta ( $\mathrm{g} / \mathrm{pl})$. Piracicaba, SP, 1996/97.

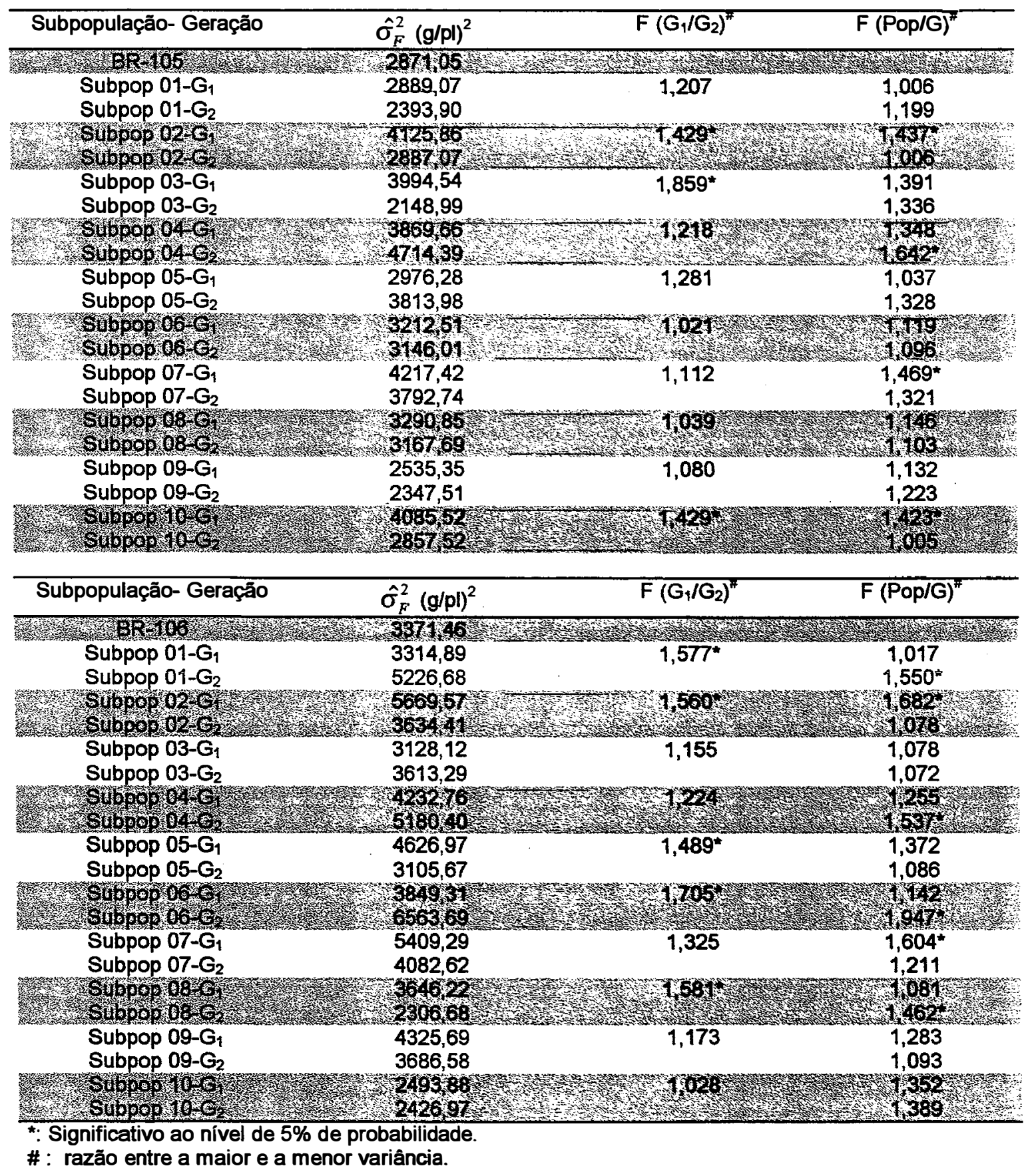


Tabela 23 - Valores da variância fenotípica $\left(\hat{\sigma}_{F}^{2}\right)$, teste $F$ entre as respectivas variâncias da primeira geração $\left(G_{1}\right)$ e segunda geração $\left(G_{2}\right)$ das subpopulações e teste $F$ entre a população e as geraçãos $G_{1}$ e $G_{2}$ de amostragem de tamanho efetivo reduzido, obtidos de uma amostra de 120 plantas das populações BR-105 e BR-106 para o caráter altura da planta (cm/pl). Piracicaba, SP, 1996/97.

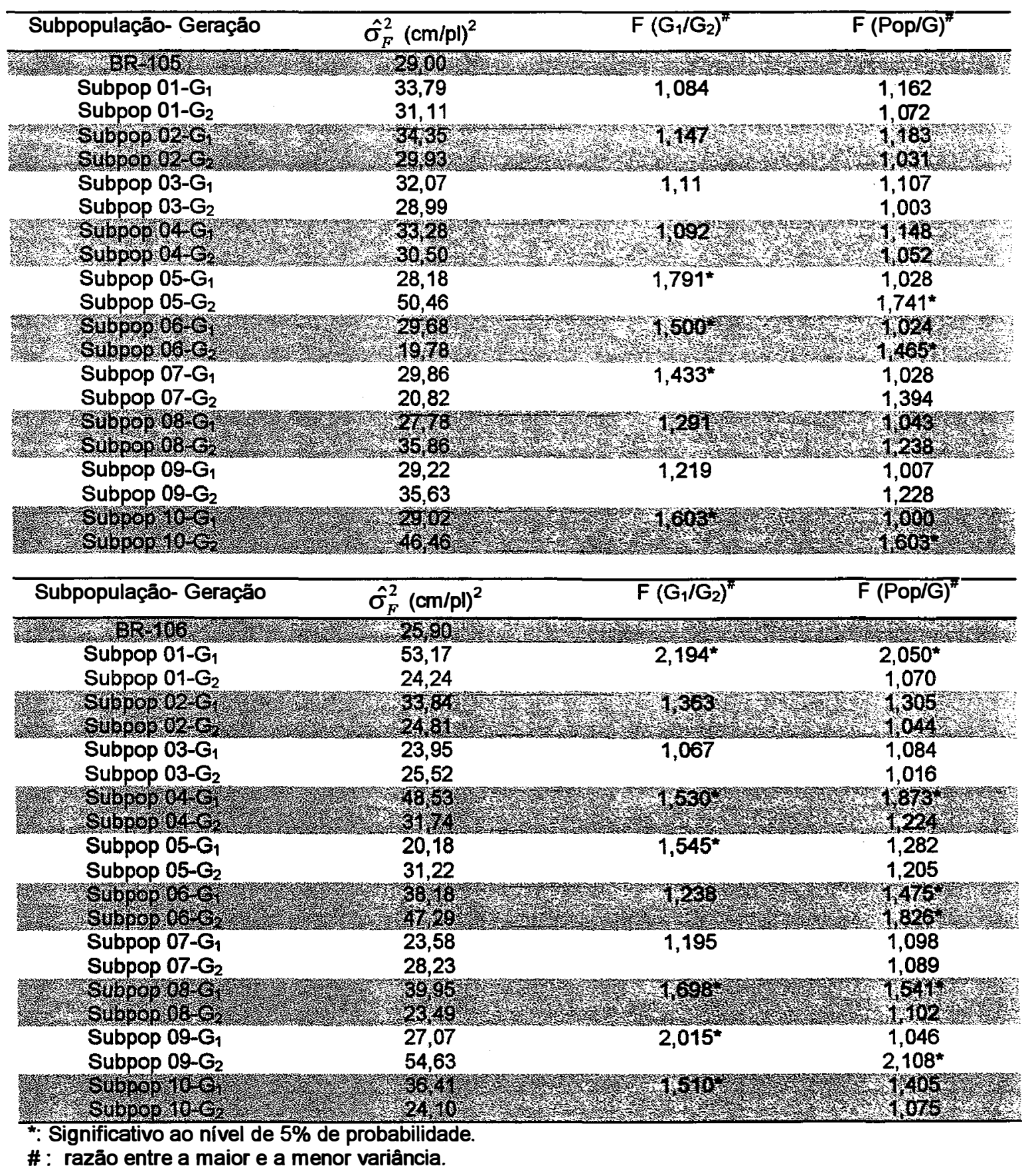


Tabela 24 - Valores da variância fenotípica $\left(\hat{\sigma}_{F}^{2}\right)$, teste $F$ entre as respectivas variâncias da primeira geração $\left(G_{1}\right)$ e segunda geração $\left(G_{2}\right)$ das subpopulações e teste $F$ entre a população e as geraçãos $G_{1}$ e $G_{2}$ de amostragem de tamanho efetivo reduzido, obtidos de uma amostra de 120 plantas das populações BR-105 e BR-106 para o caráter altura da espiga (cm/pl). Piracicaba, SP, 1996/97.

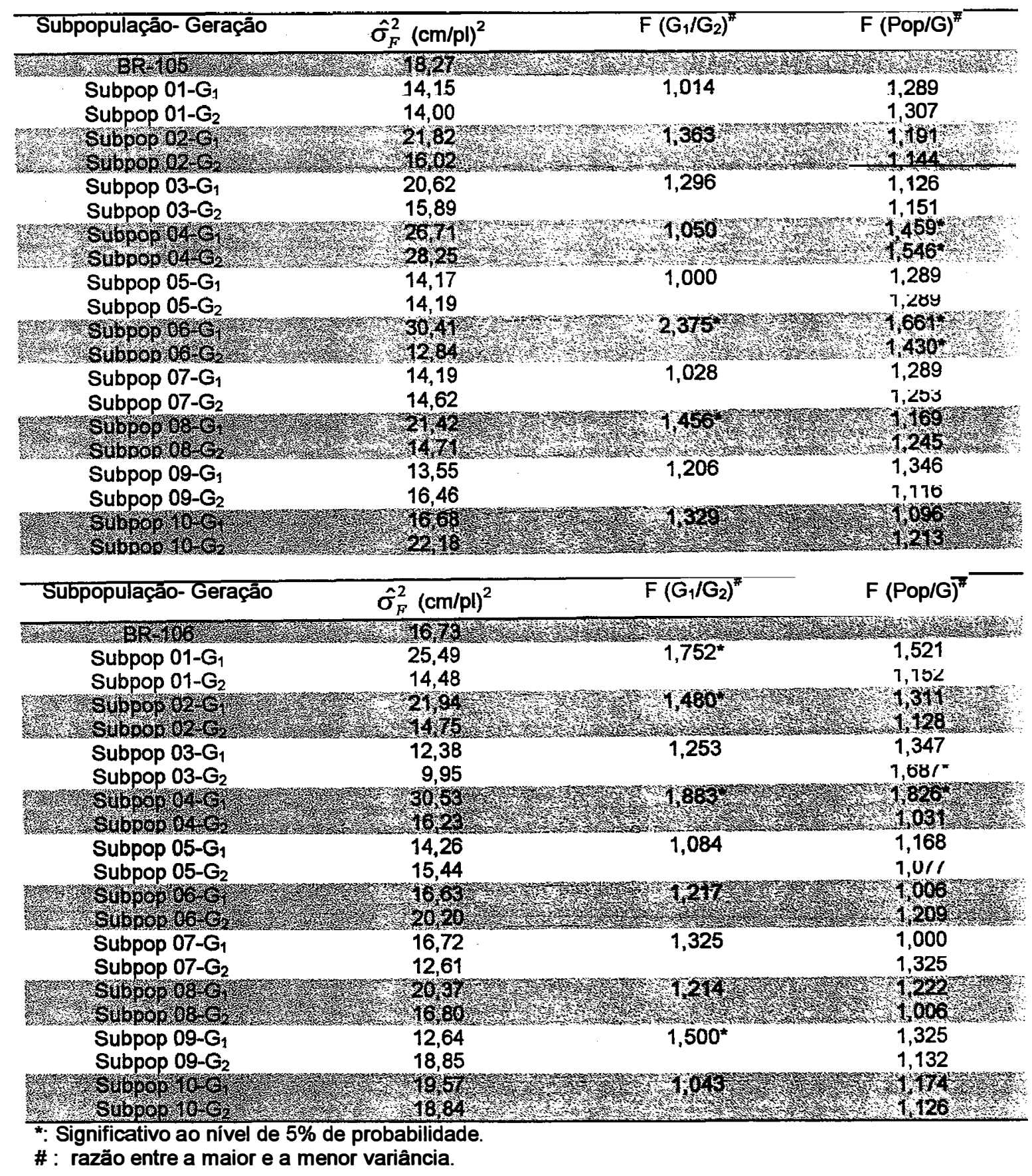


Tabela 25 -Teste de normalidade (W) e estimativas dos coeficientes de assimetria e curtose das distribuições de frequência de uma amostra de 120 plantas da população BR-105 e BR-106, das 10 subpopulações da primeira geração $\left(G_{1}\right)$ e respectivas subpopulações da segunda geração $\left(G_{2}\right)$ de amostragem de tamanho efetivo reduzido para o carater peso de grãos por planta (g/planta). Piracicaba, SP, 1996/97.

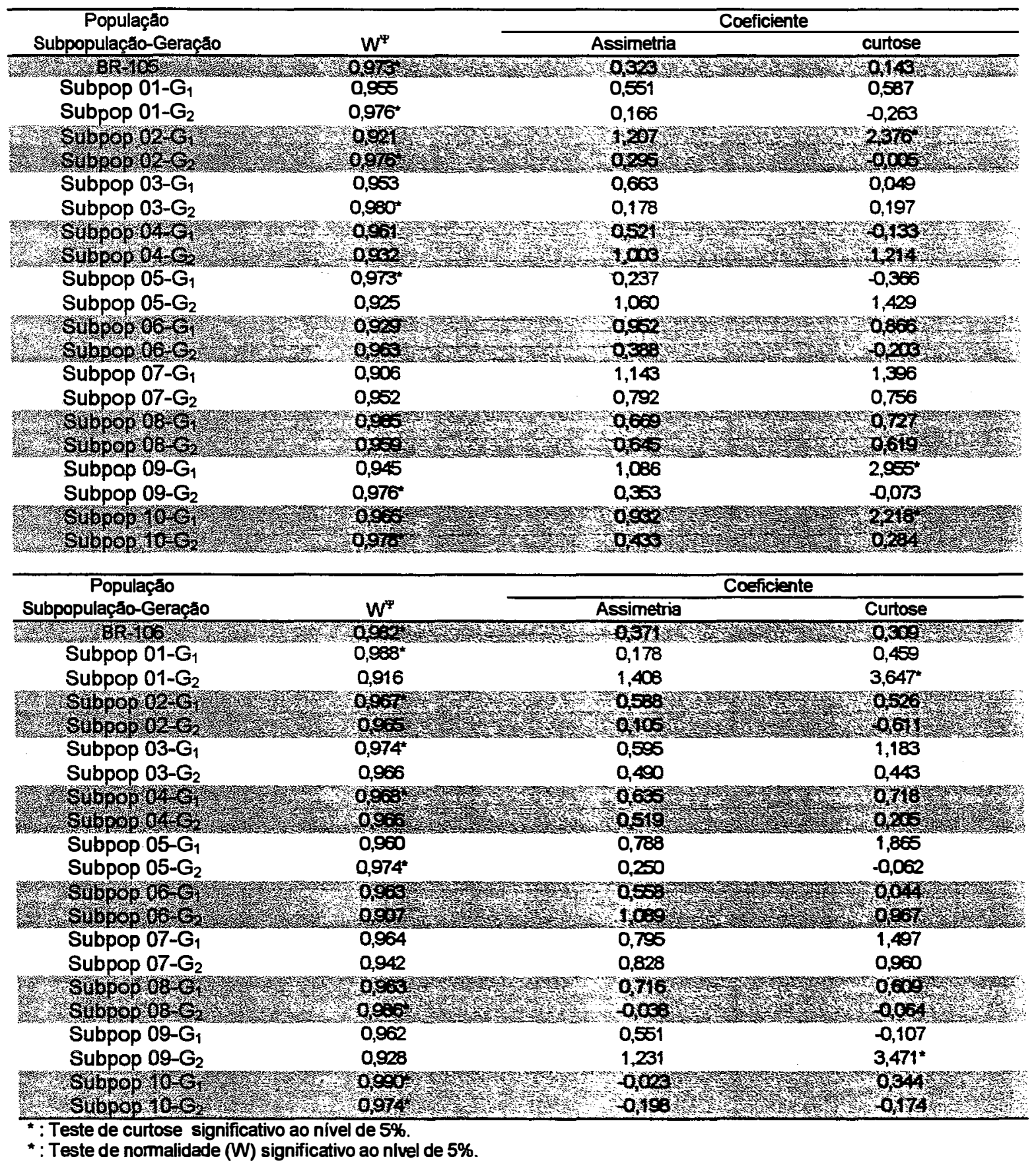


Tabela 26 - Teste de normalidade (W) e estimativas dos coeficientes de assimetria e curtose das distribuições de frequência de uma amostra de 120 plantas da população BR-105 e BR-106, das 10 subpopulações da primeira geração $\left(G_{1}\right)$ e respectivas subpopulações da segunda geração $\left(G_{2}\right)$ de amostragem de tamanho efetivo reduzido para o carater altura da planta $(\mathrm{cm} / \mathrm{pl})$. Piracicaba, SP, 1996/97.

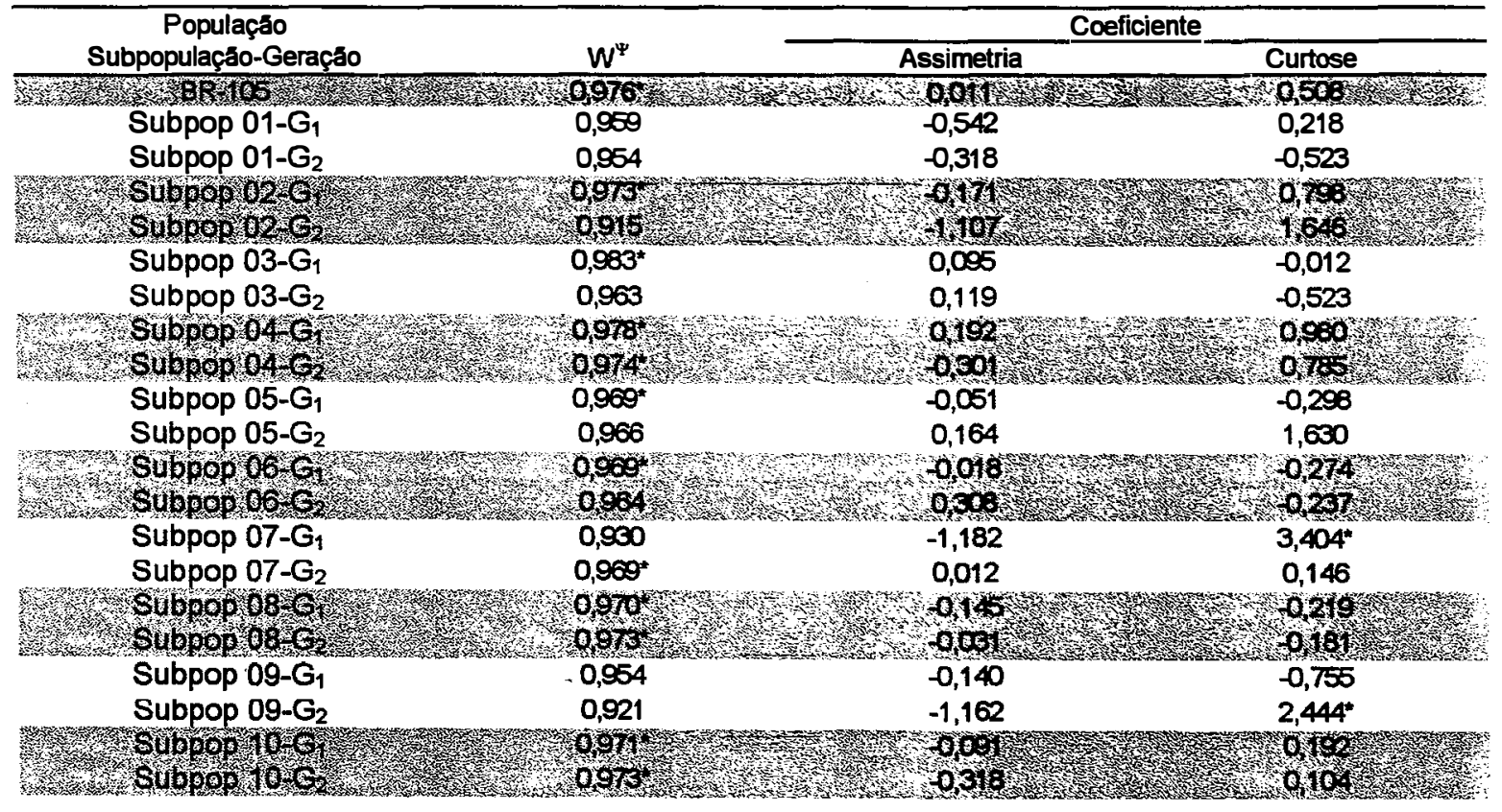

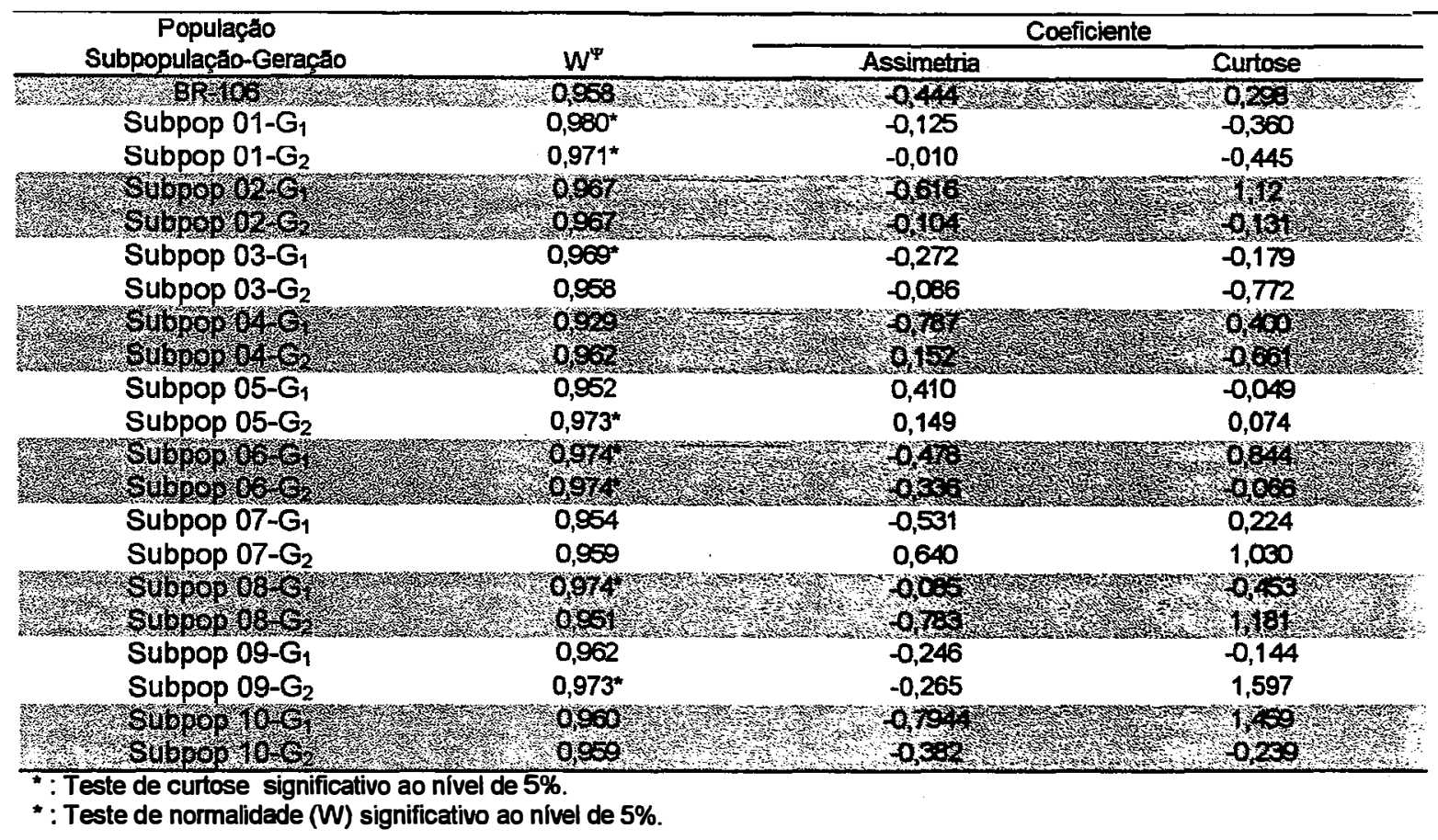


Tabela 27 - Teste de normalidade (W) e estimativas dos coeficientes de assimetria e curtose das distribuições de frequência de uma amostra de 120 plantas da população BR-105 e BR-106, das 10 subpopulações da primeira geração $\left(G_{1}\right)$ e respectivas subpopulações da segunda geração $\left(G_{2}\right)$ de amostragem de tamanho efetivo reduzido para o caráter altura da espiga $(\mathrm{cm} / \mathrm{pl})$. Piracicaba, SP, 1996/97.

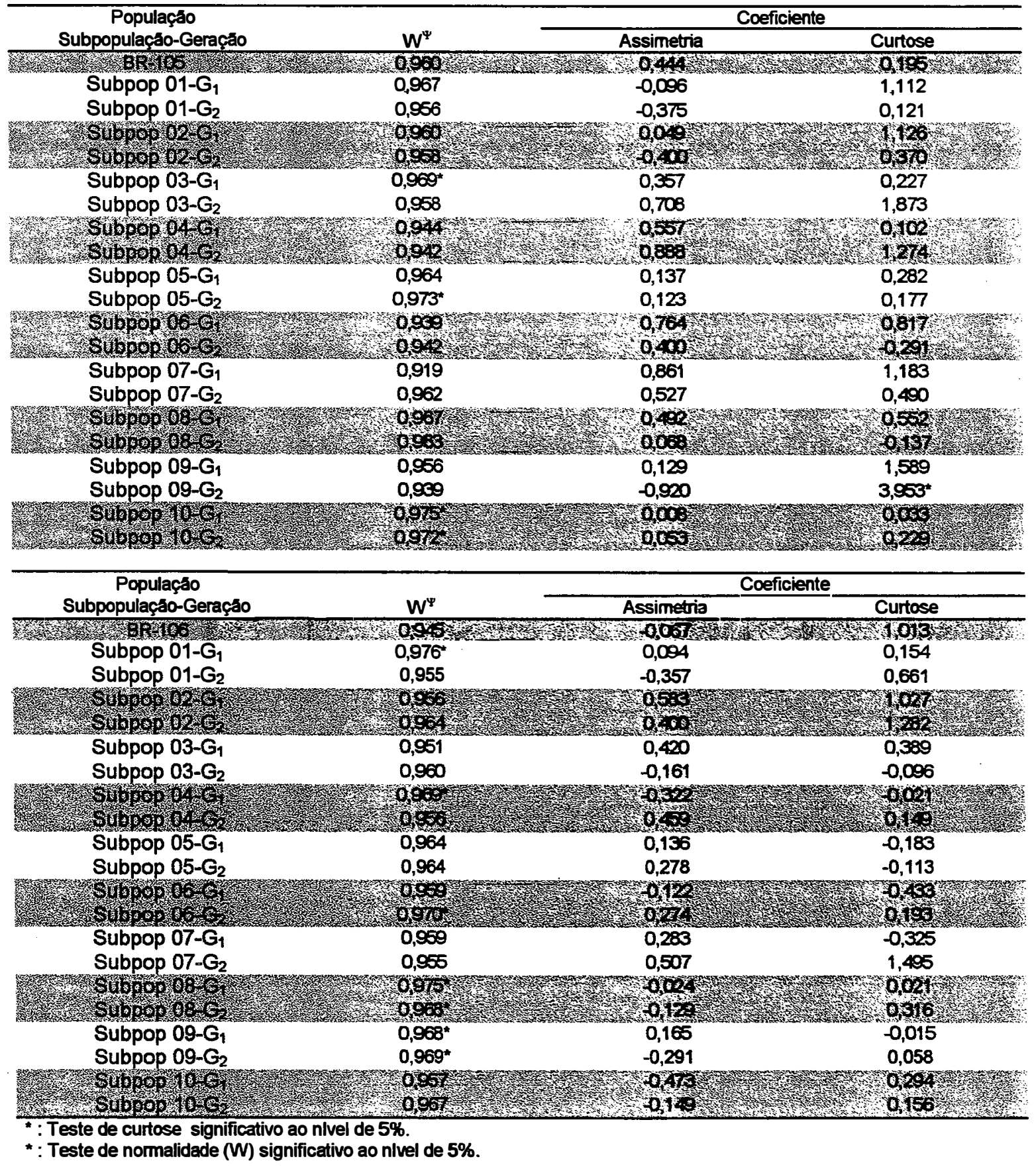


FIGURAS 
BR-105

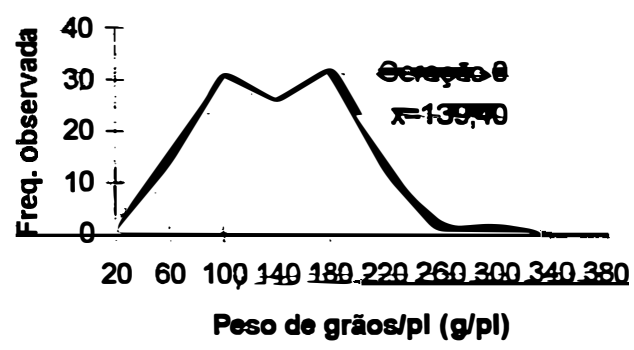

Subpopulação 01
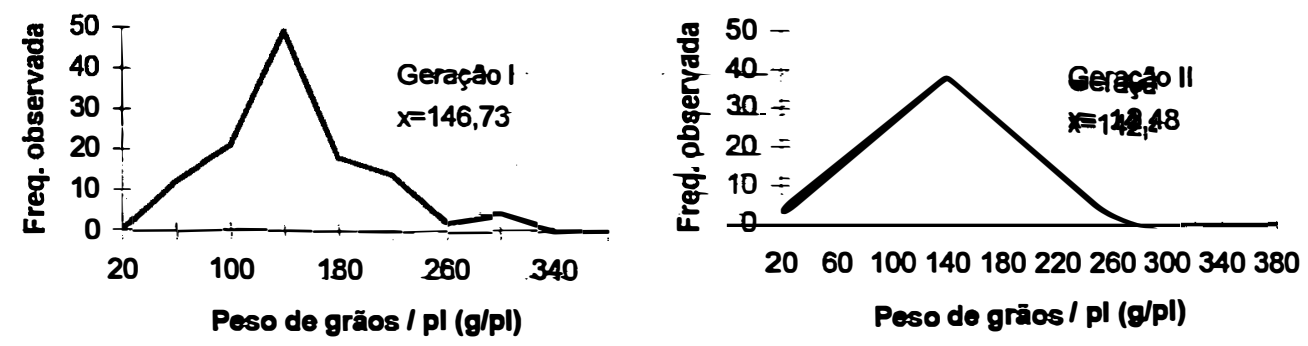

Subpopulação 02
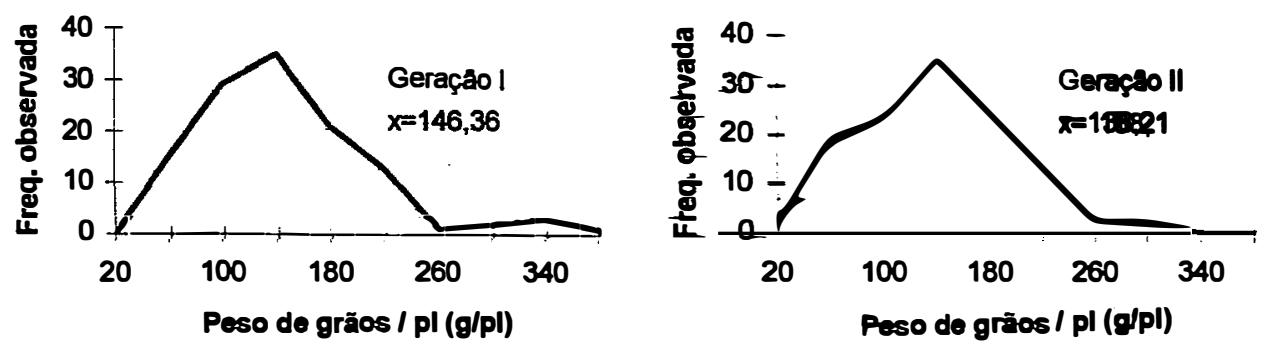

Subpopulação 03
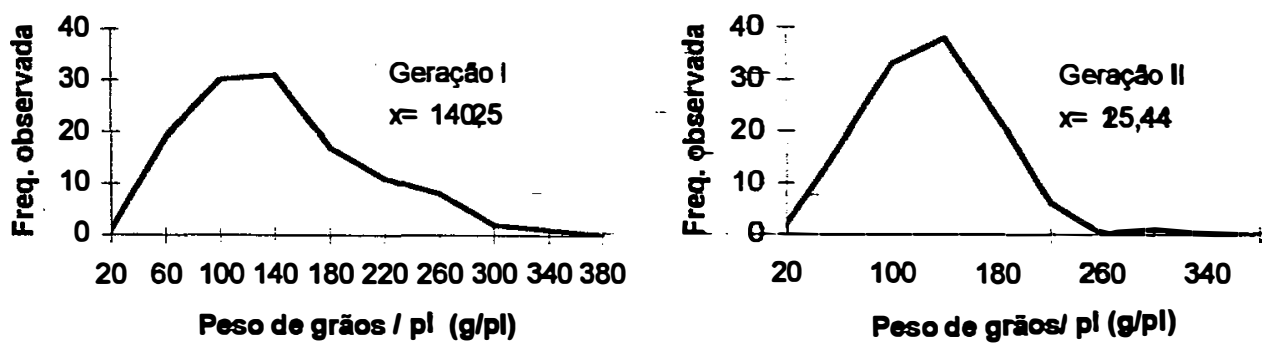

Figura 1 - Distribuição de médias do caráter peso de grãos por planta (g/pl) na população BR-105 e nas subpopulações 01, 02 e 03 nas duas gerações de amostragens de tamanho reduzido. 
Subpopulação 04
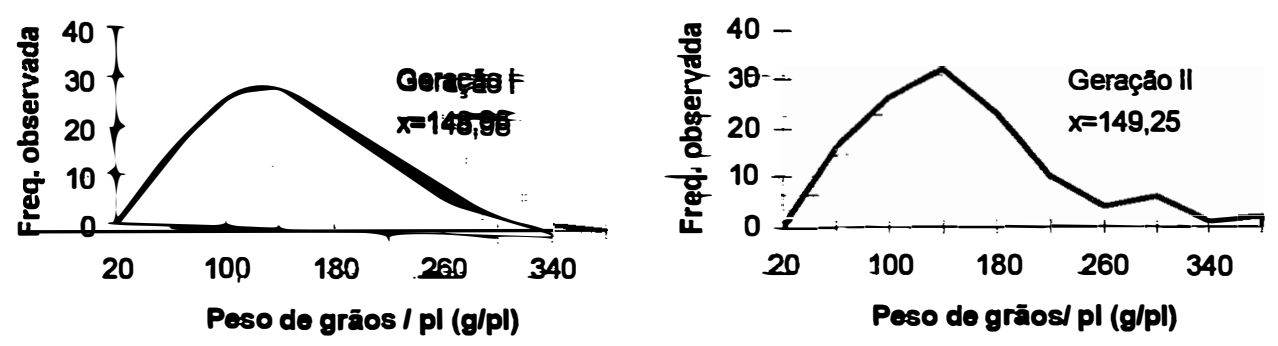

Subpopulação 05
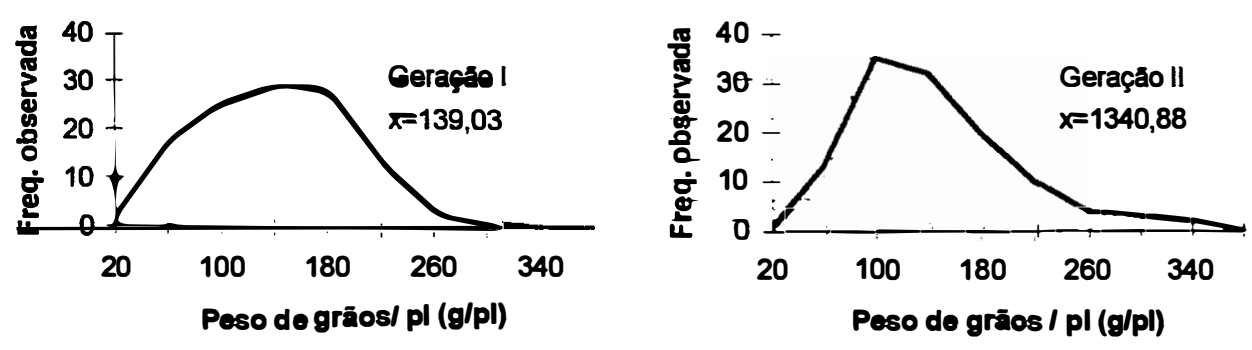

Subpopulação 06
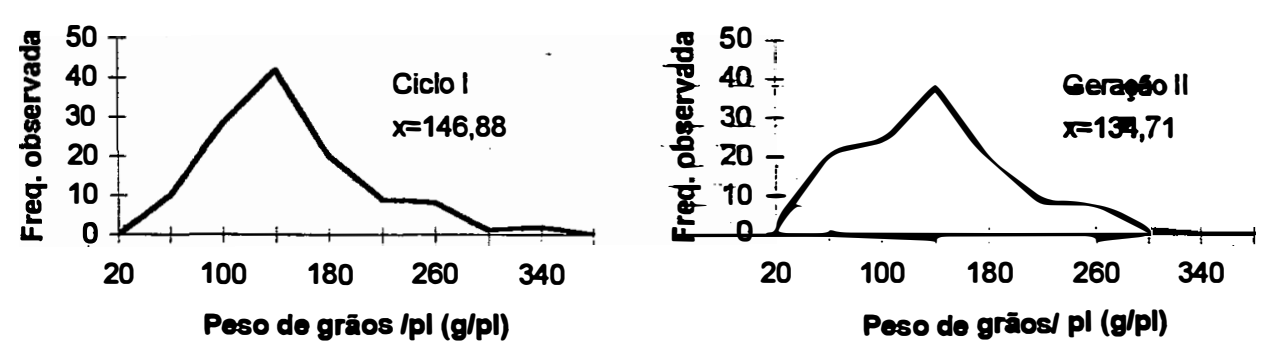

Subpopulação 07
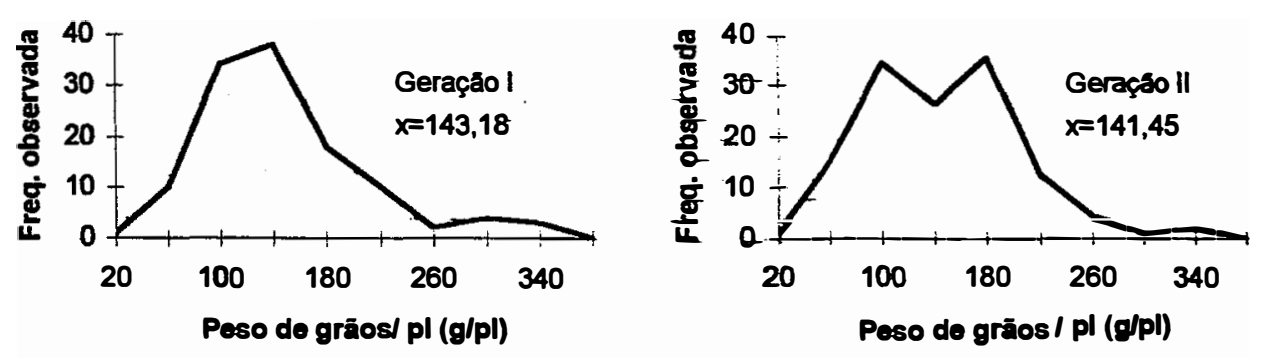

Figura 2 - Distribuição de médias do caráter peso de grãos por planta (g/pl) das subpopulações 04, 05, 06 e 07 da população BR-105, nas duas gerações de amostragens de tamanho reduzido. 
Subpopulação 08
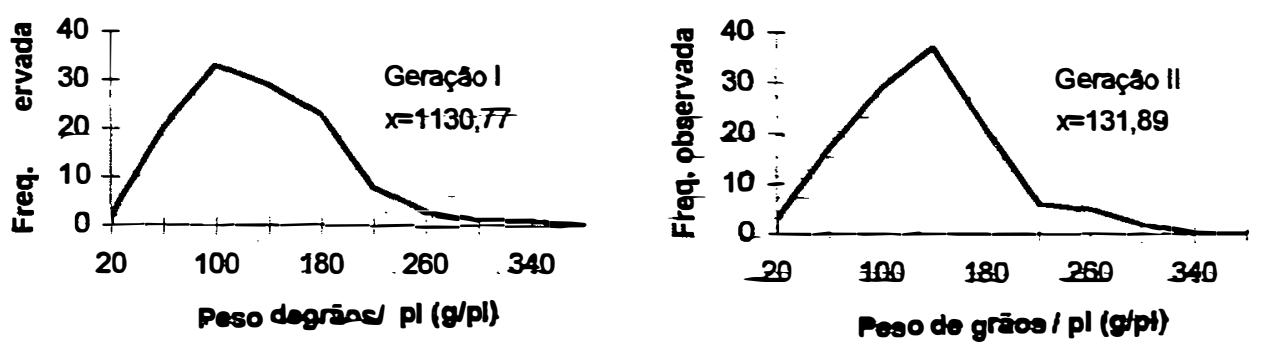

Subpopulação 09
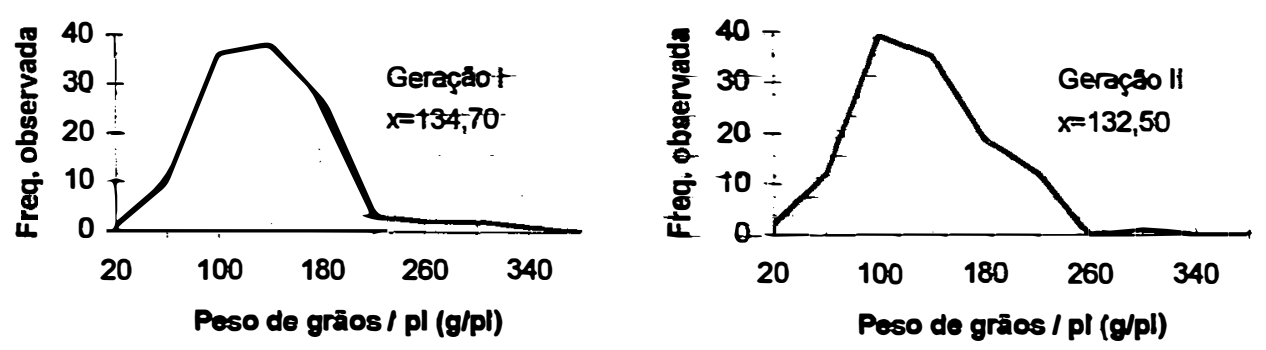

Subpopulação 10
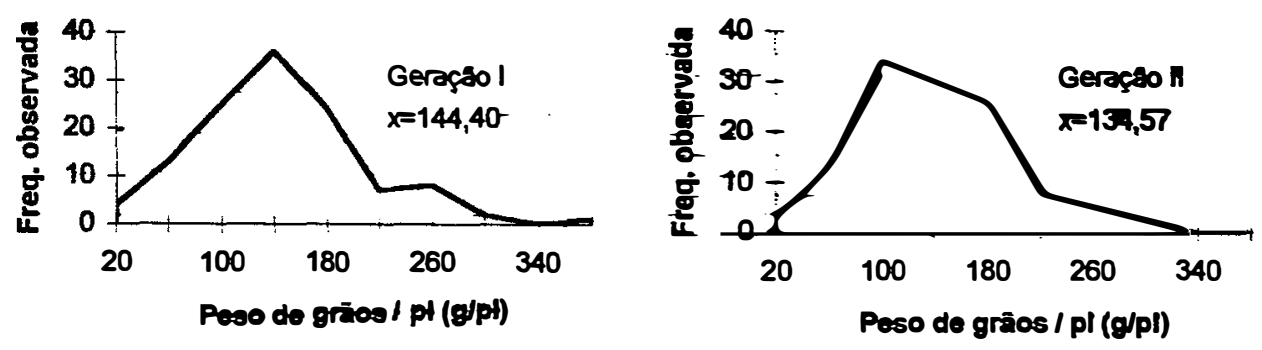

Figura 3 - Distribuição de médias do caráter peso de grãos por planta $(g / p l)$ das subpopulações 08, 09 e 10 da população BR-105, nas duas gerações de amostragens de tamanho reduzido. 


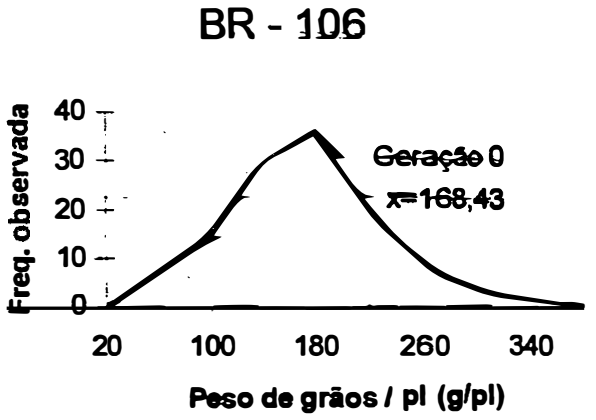

Subpopulação 01
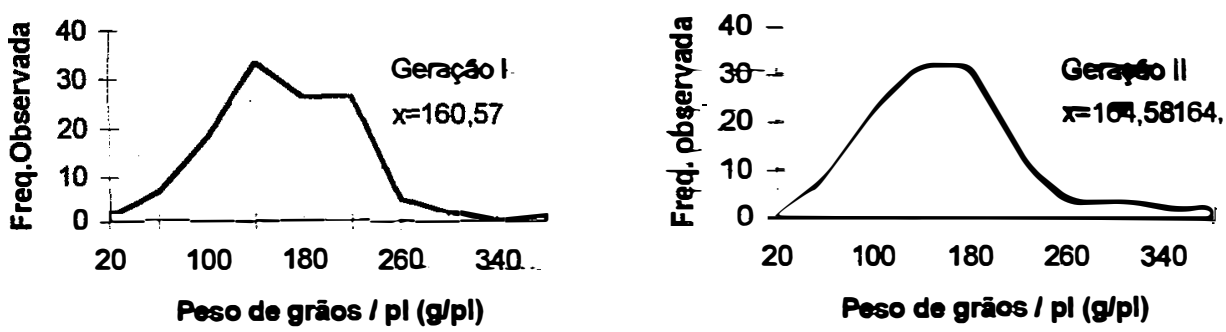

Subpopulação 02
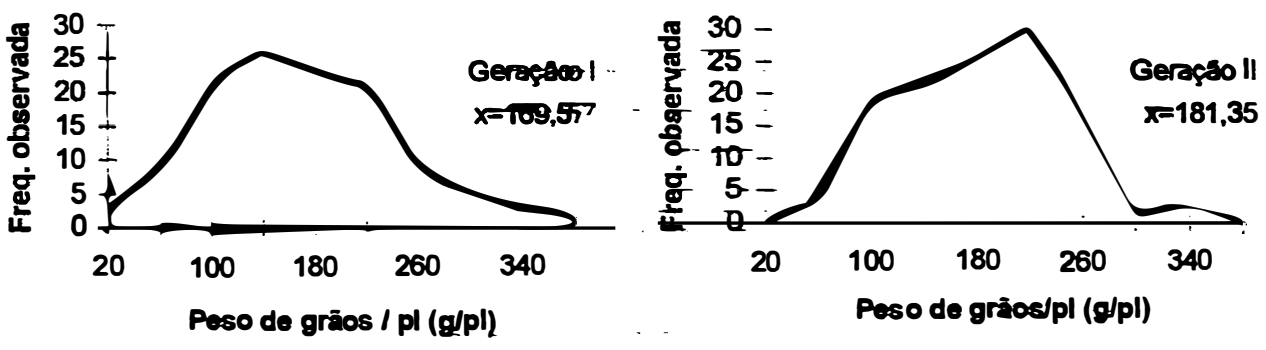

Subpopulação 03
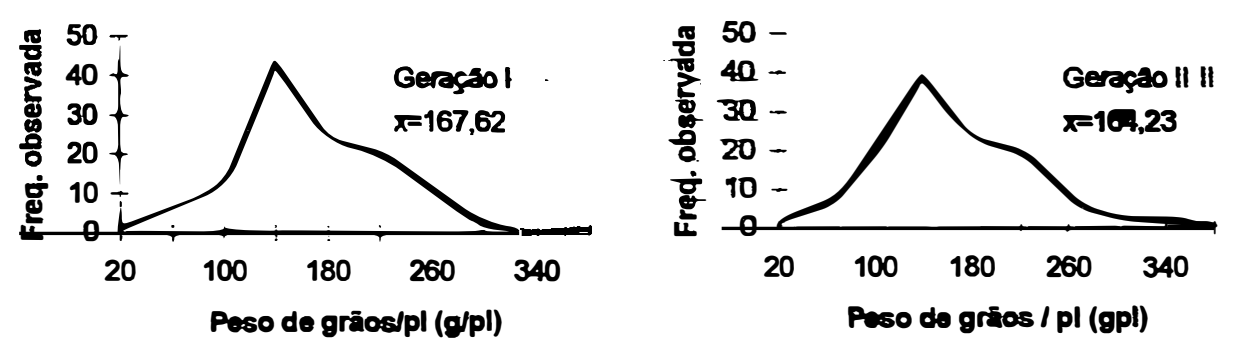

Figura 4 - Distribuição de médias do caráter peso de grãos por planta $(\mathrm{g} / \mathrm{pl})$ na população BR-106 e nas subpopulações 01,02 e 03 nas duas geraçōes de amostragens de tamanho reduzido. 
Subpopulação 04
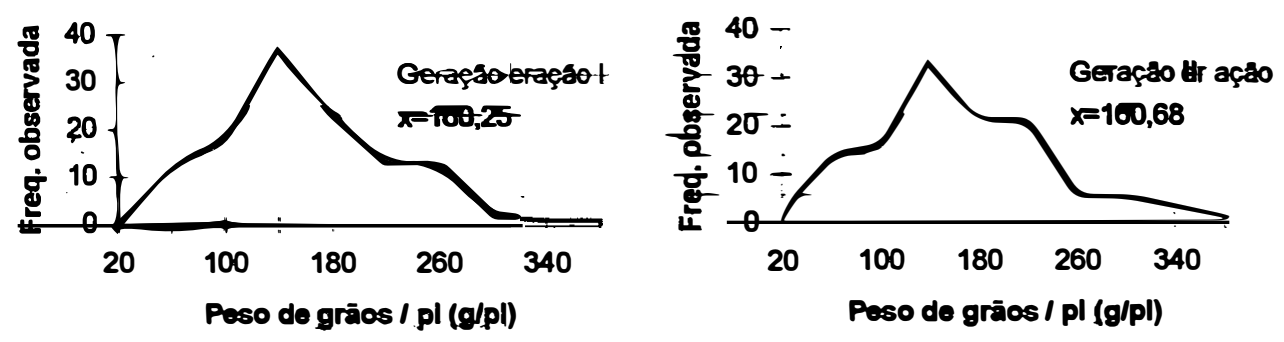

Subpopulação 05
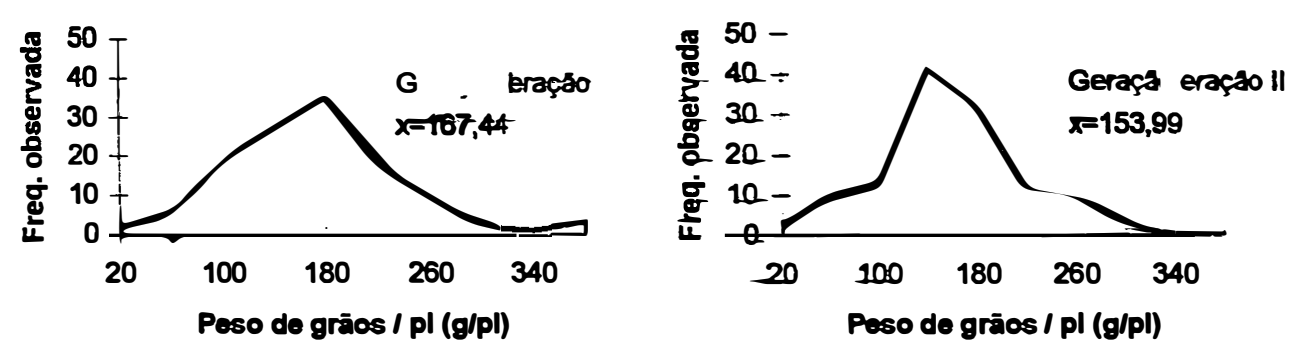

Subpopulação 06
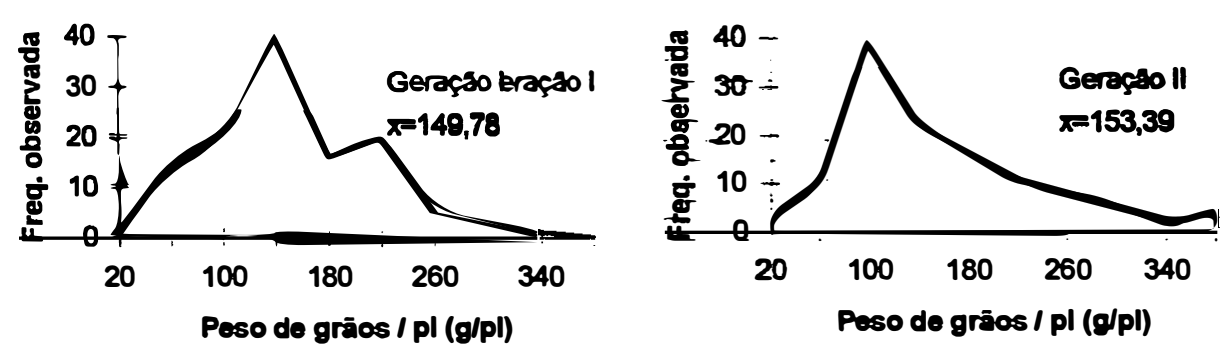

Subpopulação 07
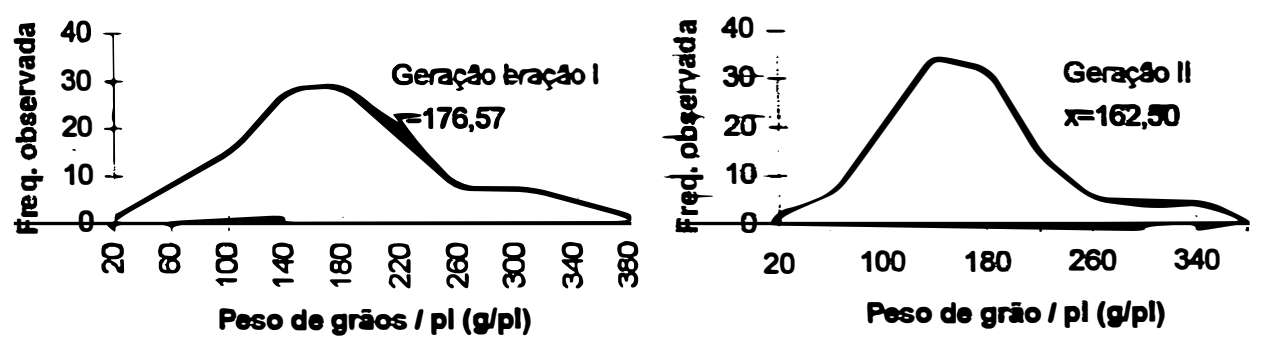

Figura 5 - Distribuição de médias do caráter peso de grãos por planta $(g / p l)$ das subpopulações 04, 05, 06 e 07 da população BR-106, nas duas gerações de amostragens de tamanho reduzido. 
Subpopulação 08
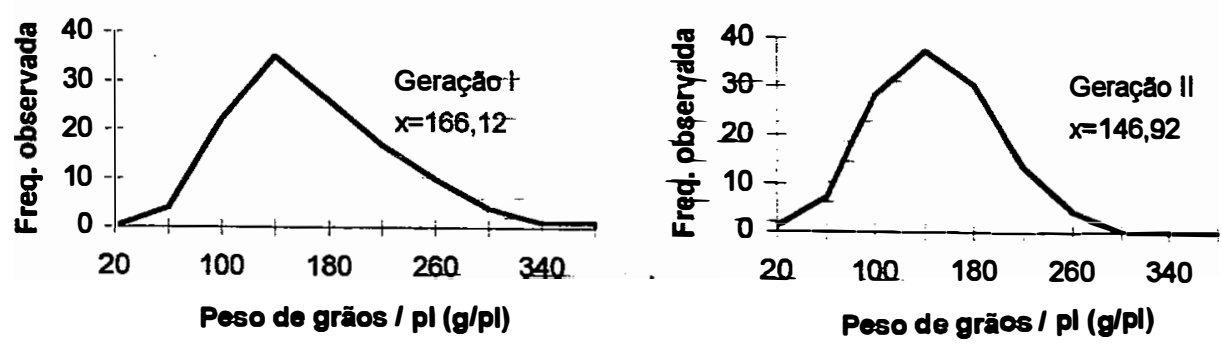

Subpopulação 09
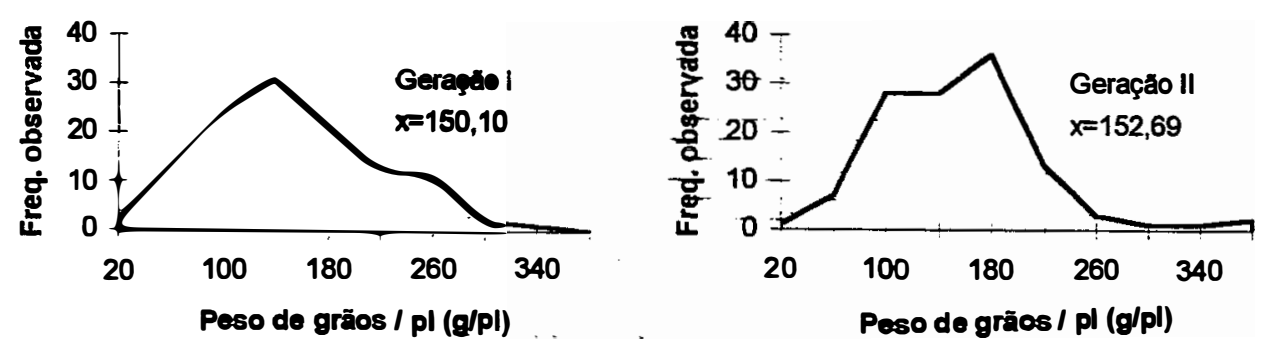

Subpopulação 10
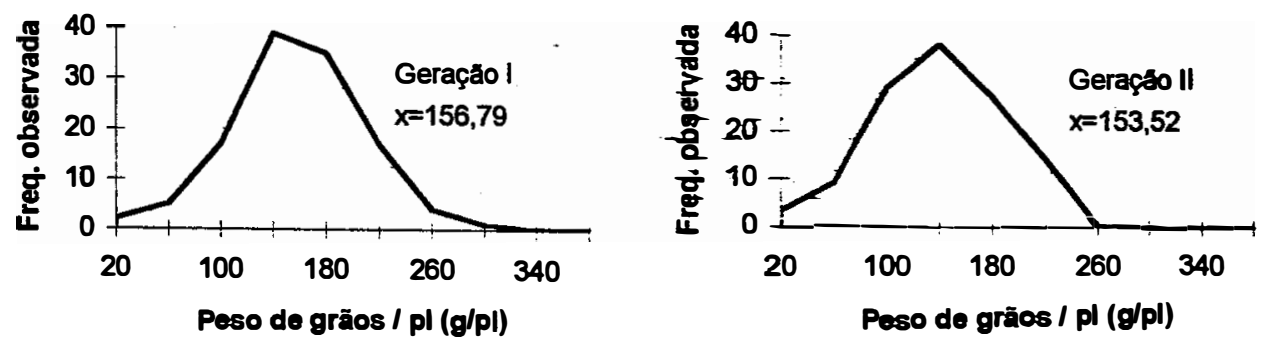

Figura 6 - Distribuição de médias do caráter peso de grãos por planta (g/pl) das subpopulações 08, 09 e 10 da população BR-106, nas duas gerações de amostragens de tamanho reduzido. 
BR-105

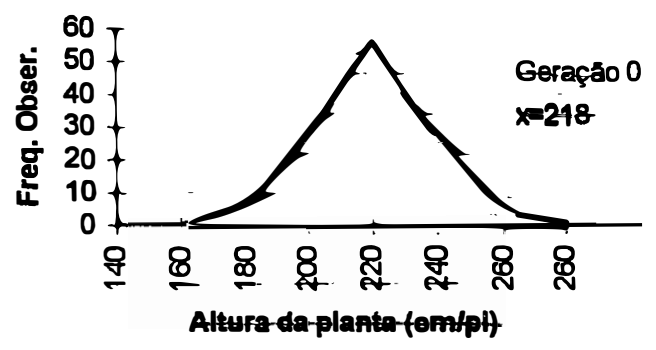

Subpopulação 01
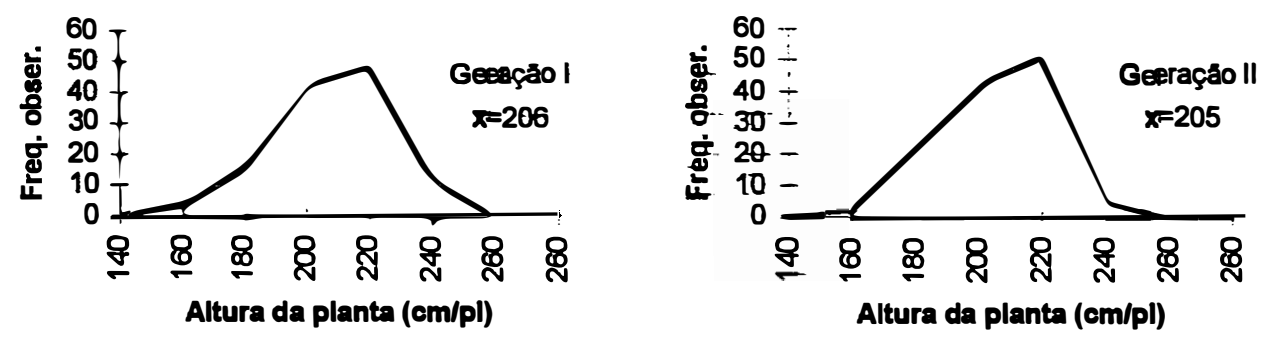

Subpopulação 02
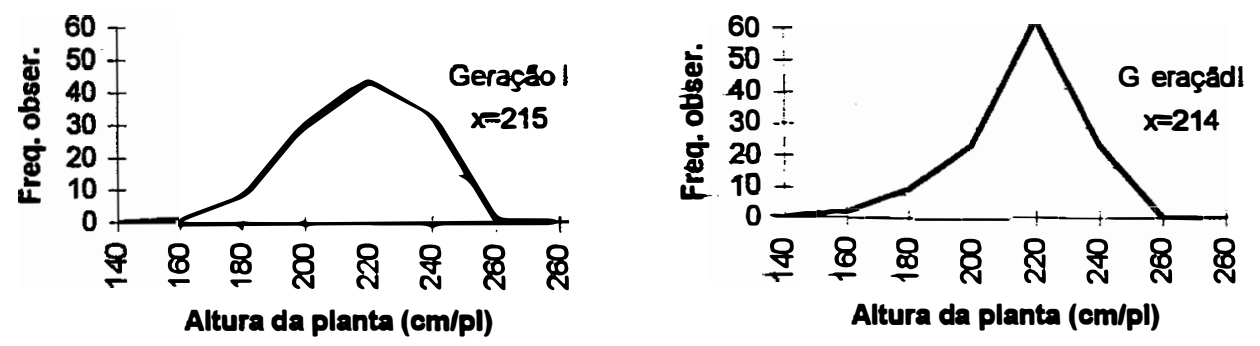

Subpopulação 03
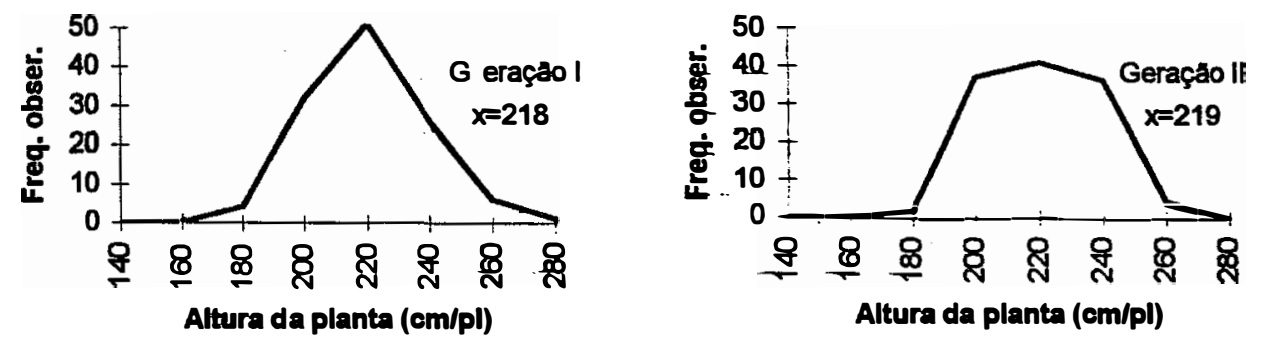

Figura 7 - Distribuição de médias do caráter altura da planta $(\mathrm{cm} / \mathrm{pl})$ na população BR-105 e nas subpopulações 01, 02 e 03 nas duas geraçōes de amostragens de tamanho reduzido. 
Subpopulação 04
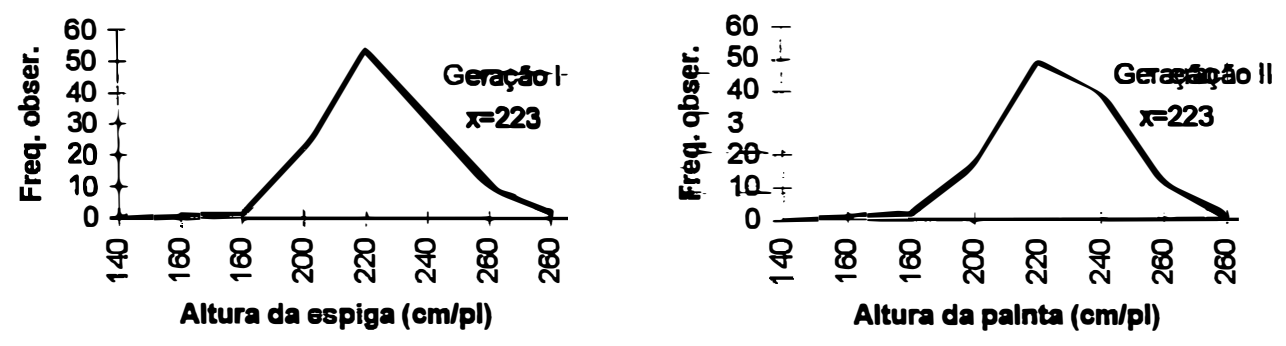

Subpopulação 05
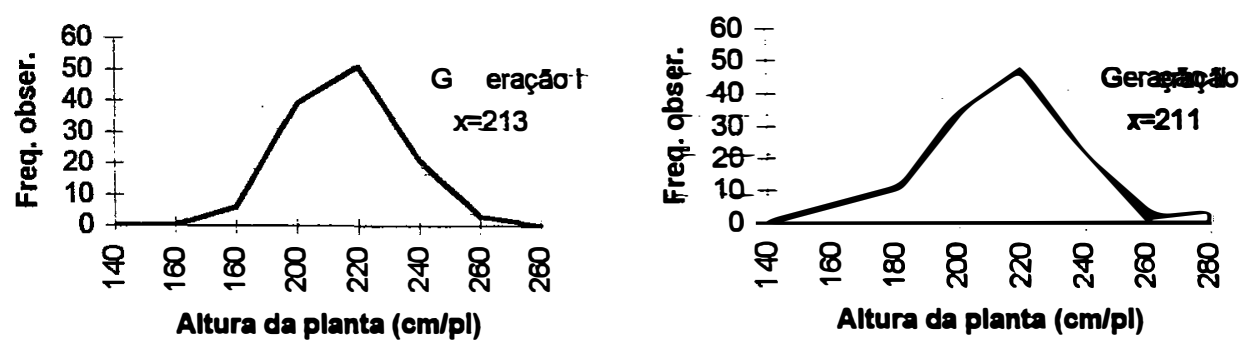

Subpopulação 06
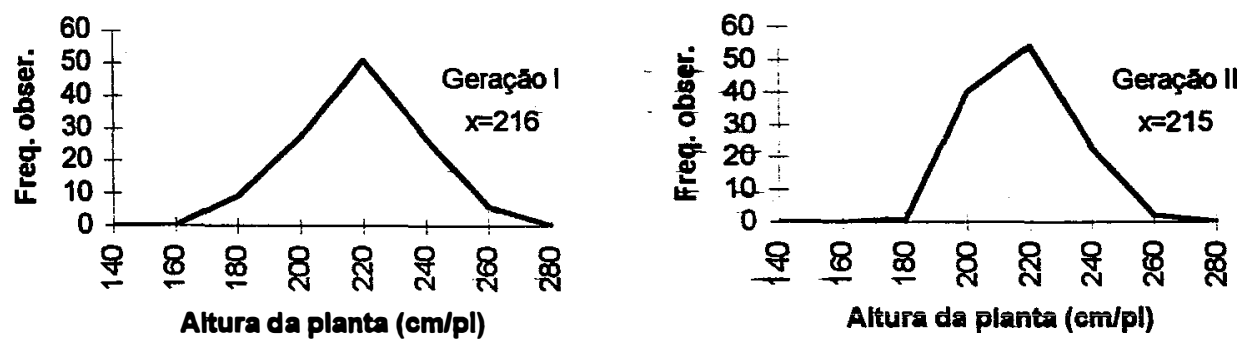

Subpopulação 07
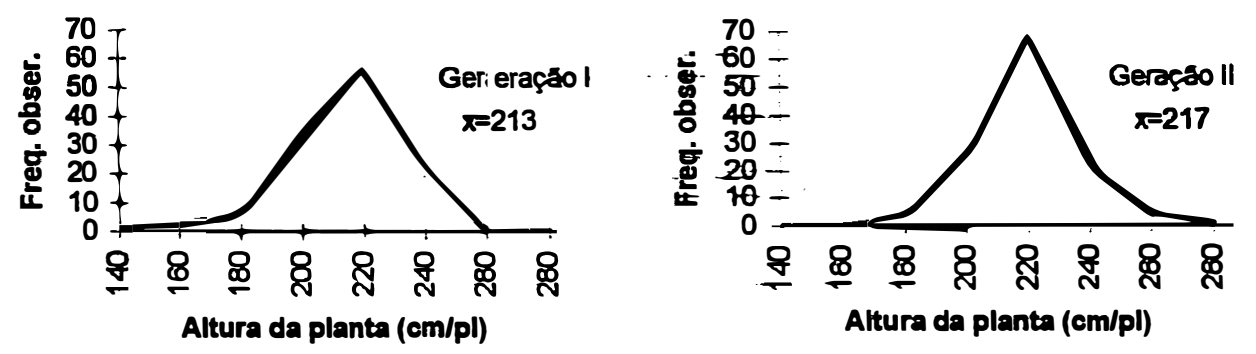

Figura 8 - Distribuição de médias do caráter altura da planta $(\mathrm{cm} / \mathrm{pl})$ das subpopulações 04, 05, 06 e 07 da população BR-105, nas duas gerações de amostragens de tamanho reduzido. 
Subpopulação 08
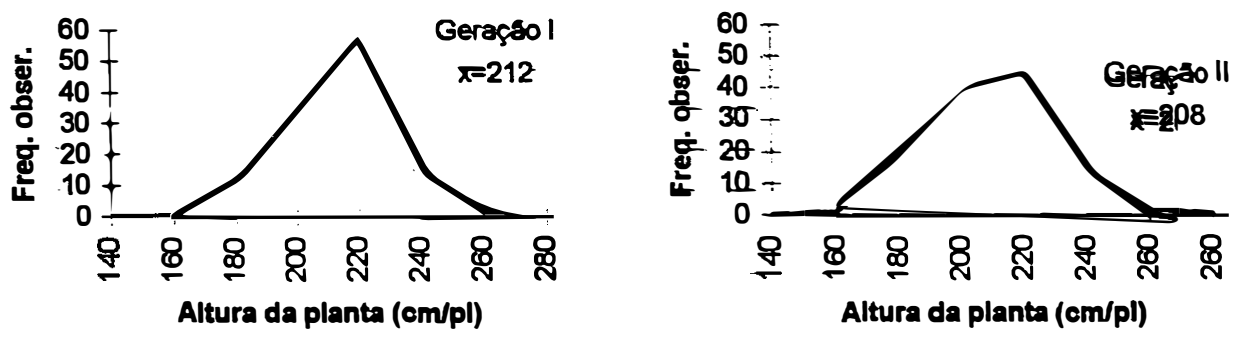

Subpopulação 09
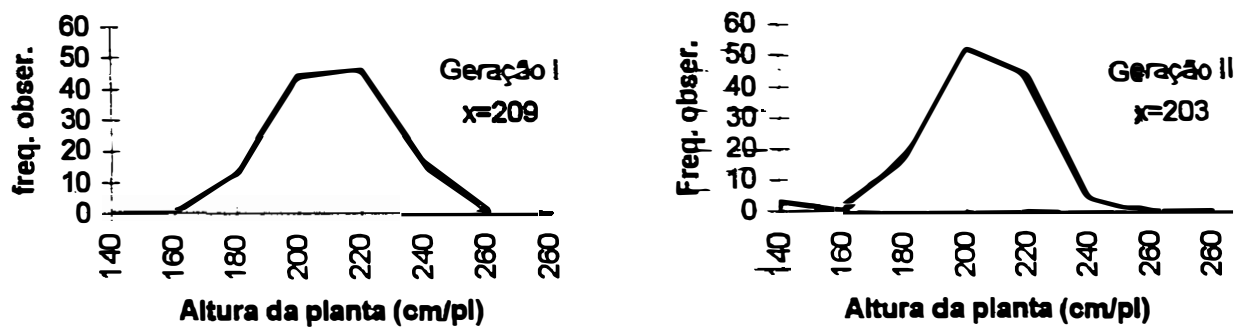

Subpopulação 10
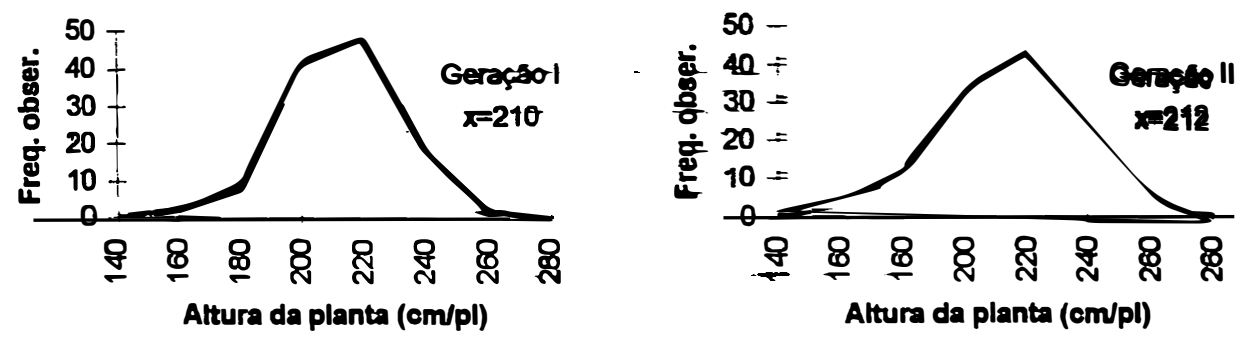

Figura 9 - Distribuição de médias do caráter altura da planta $(\mathrm{cm} / \mathrm{pl})$ das subpopulações 08,09 e 10 da população BR-105, nas duas gerações de amostragens de tamanho reduzido. 
BR-106

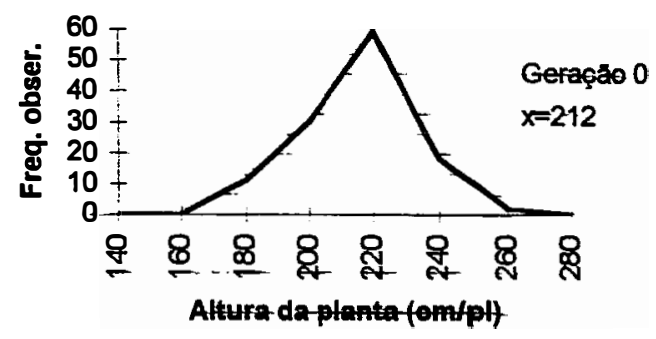

Subpopulação 01
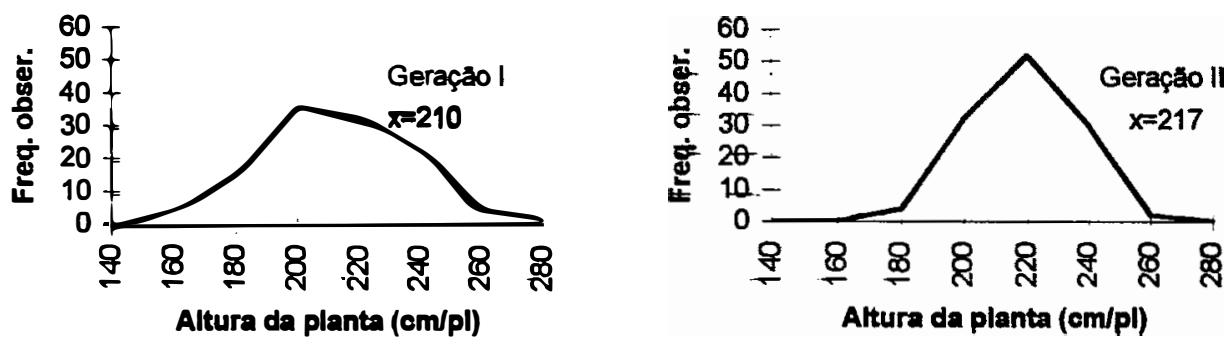

Subpopulação 02
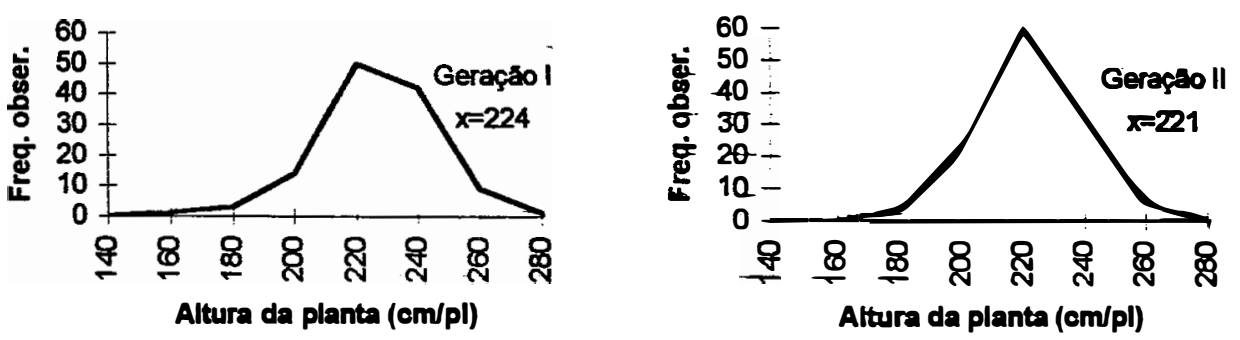

Subpopulação 03
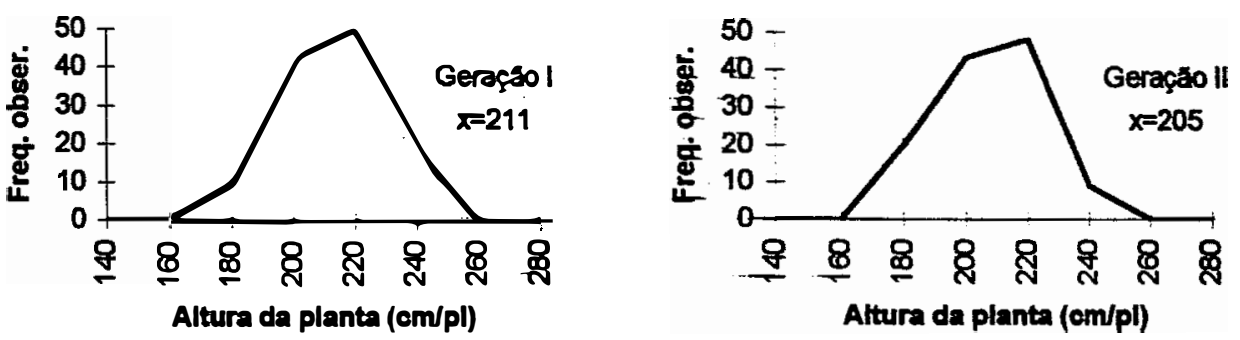

Figura 10 - Distribuição de médias do caráter altura da planta $(\mathrm{cm} / \mathrm{pl})$ na população BR-106 e nas subpopulações 01, 02 e 03 nas duas gerações de amostragens de tamanho reduzido. 
Subpopulação 04
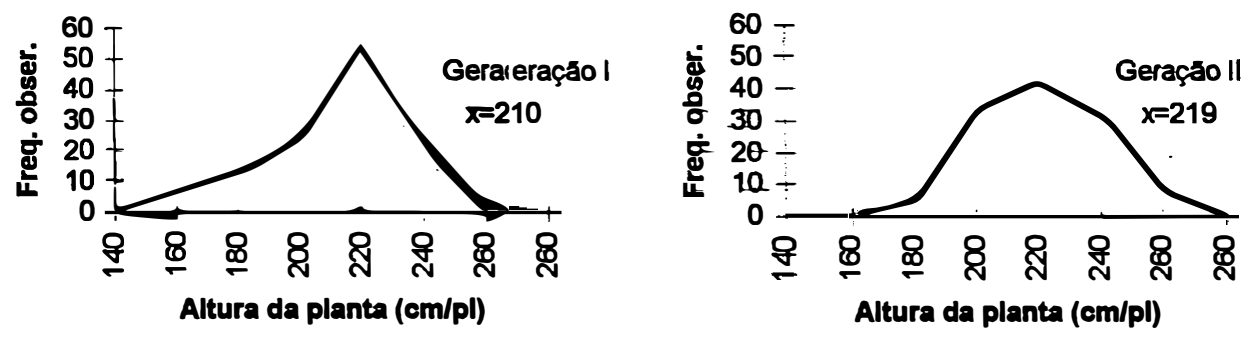

Subpopulação 05
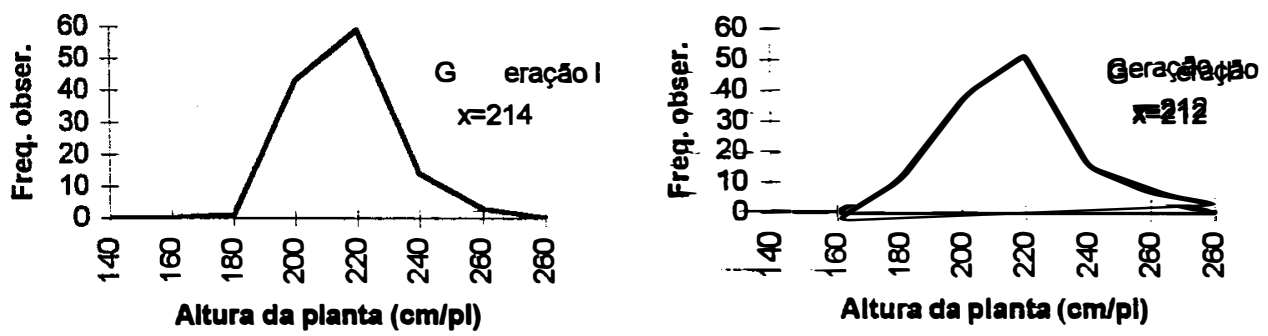

Subpopulação 06
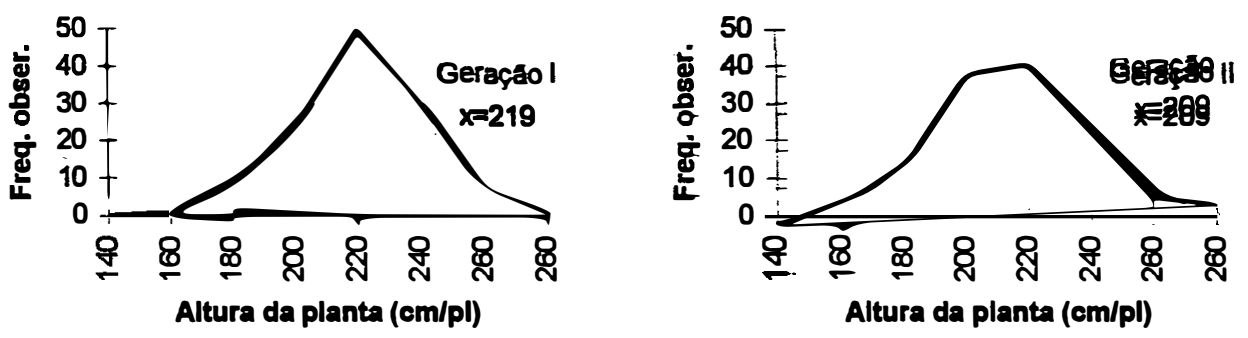

Subpopulação 07
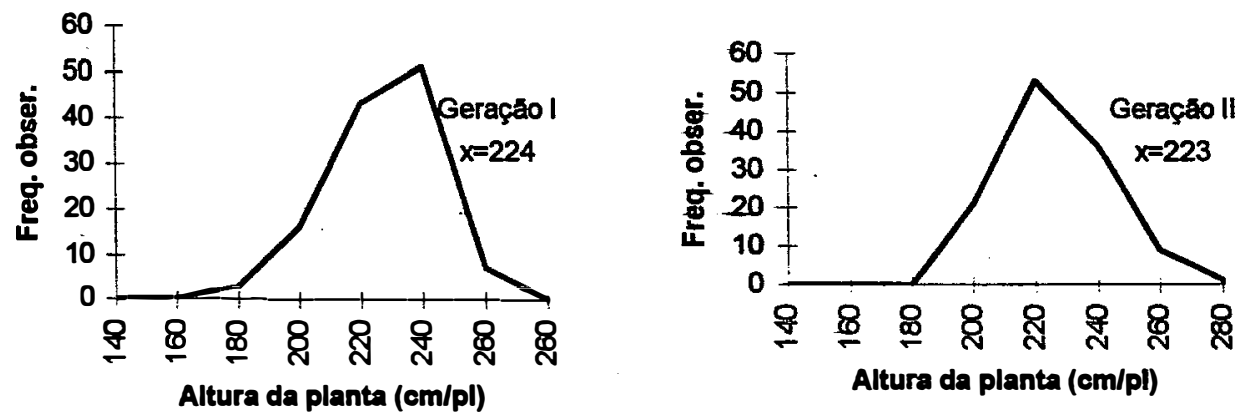

Figura 11 - Distribuição de médias do caráter altura da planta $(\mathrm{cm} / \mathrm{pl})$ das subpopulações 04, 05, 06 e 07 da populaçāo BR-106, nas duas gerações de amostragens de tamanho reduzido. 
Subpopulação 08
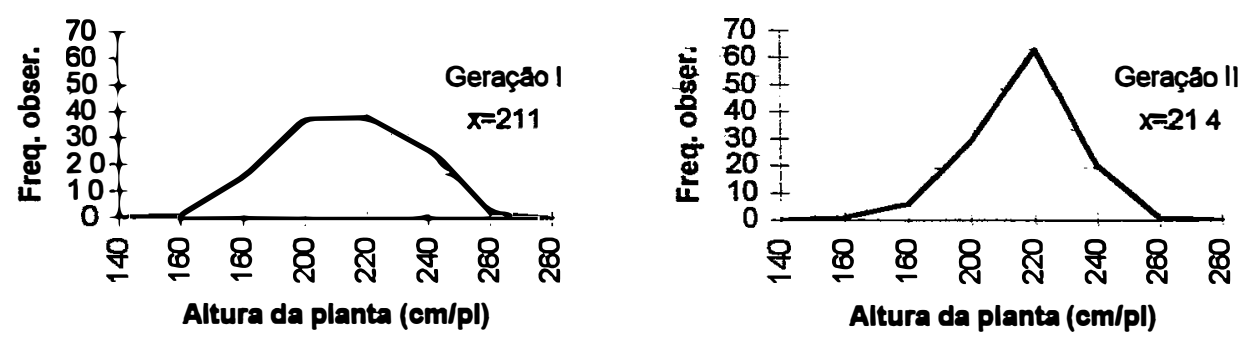

Subpopulação 09
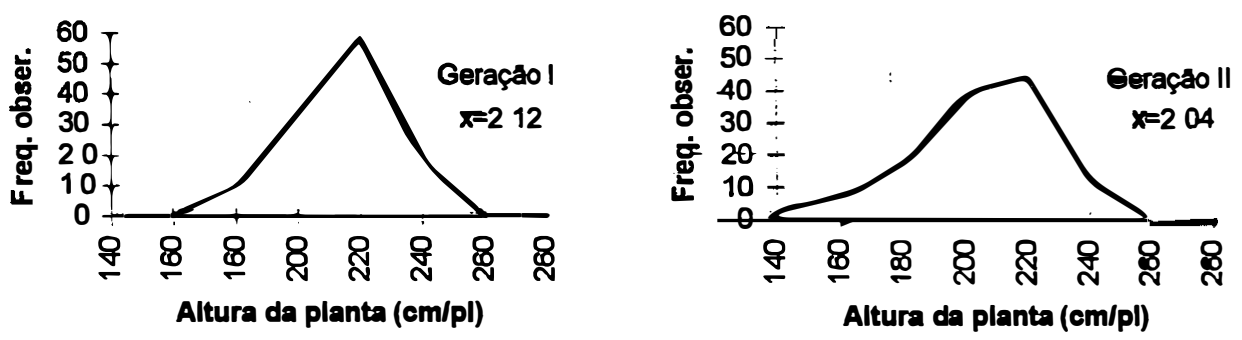

Subpopulação 10
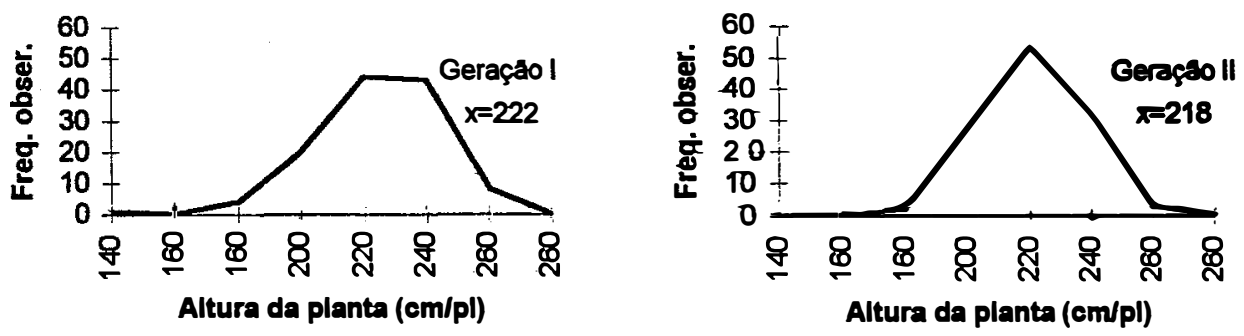

Figura 12 - Distribuição de médias do caráter altura da planta $(\mathrm{cm} / \mathrm{pl})$ das subpopulações 08, 09 e 10 da população BR-106, nas duas gerações de amostragens de tamanho reduzido. 
BR-105

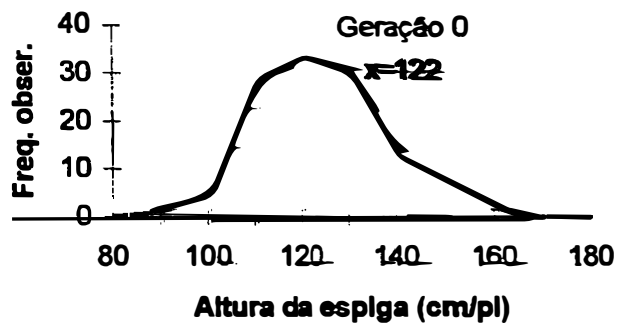

Subpopulação 01
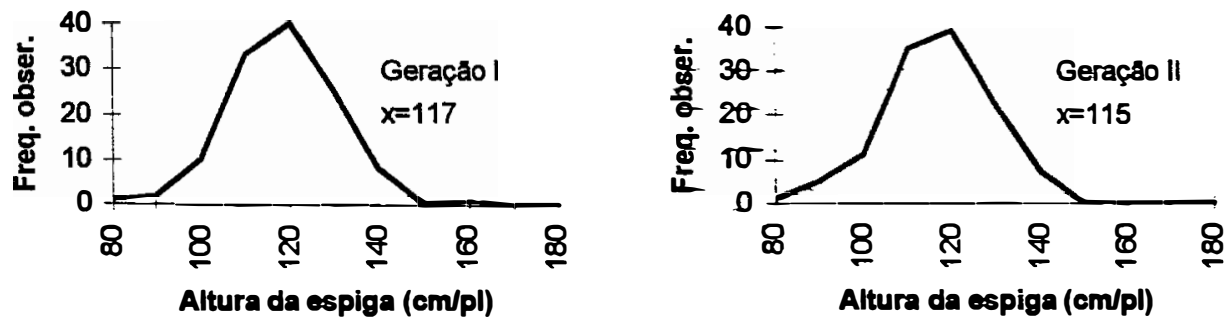

Subpopulação 02
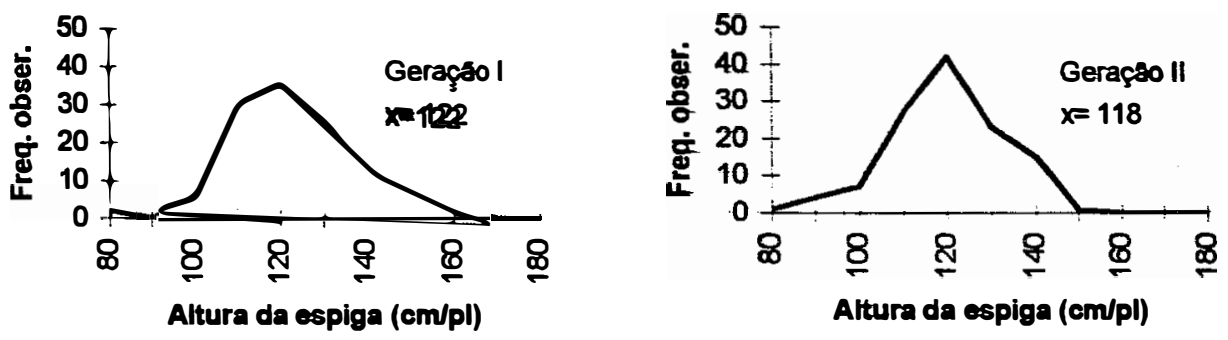

Subpopulação 03
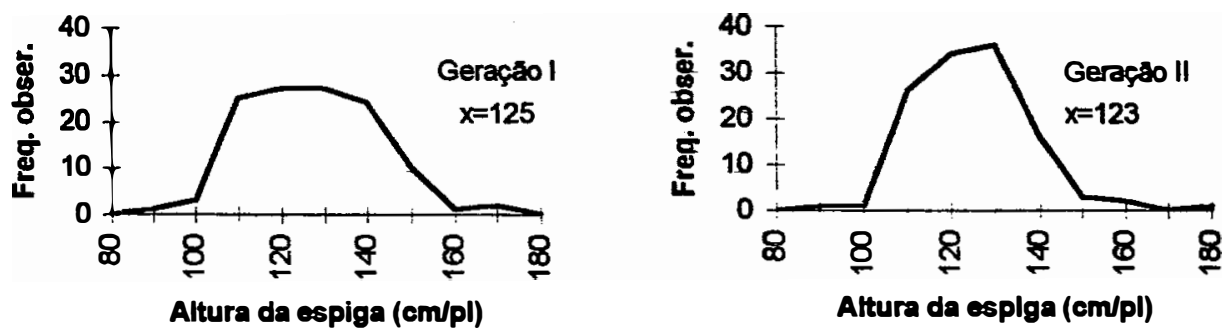

Figura 13 - Distribuição de médias do caráter caráter altura da espiga (cm/pl) na população BR-105 e nas subpopulações 01, 02 e 03 nas duas gerações de amostragens de tamanho reduzido. 
Subpopulação 04
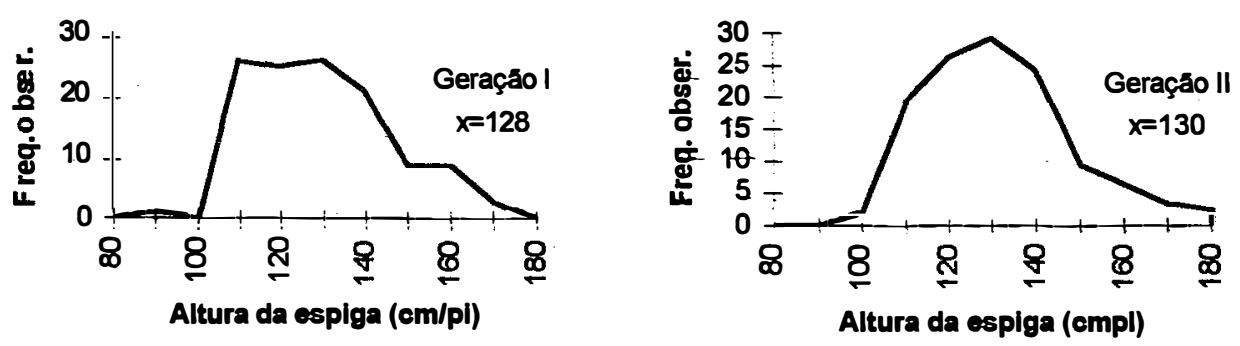

Subpopulação 05
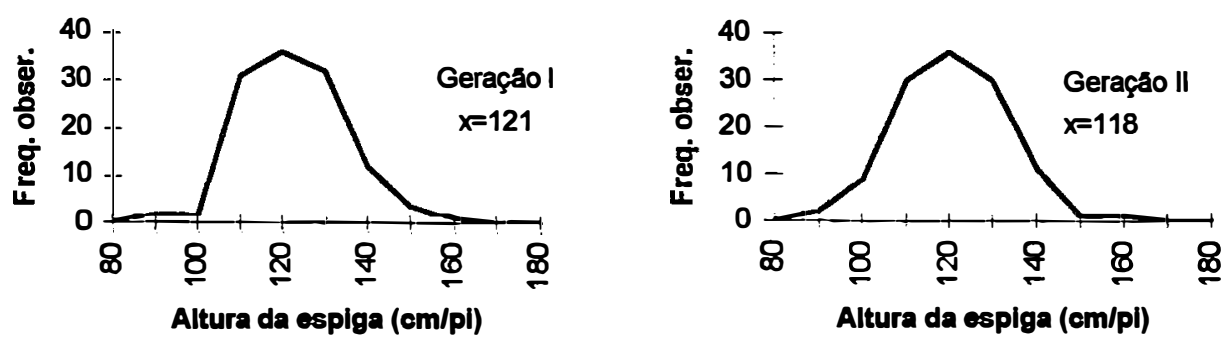

Subpopulação 06
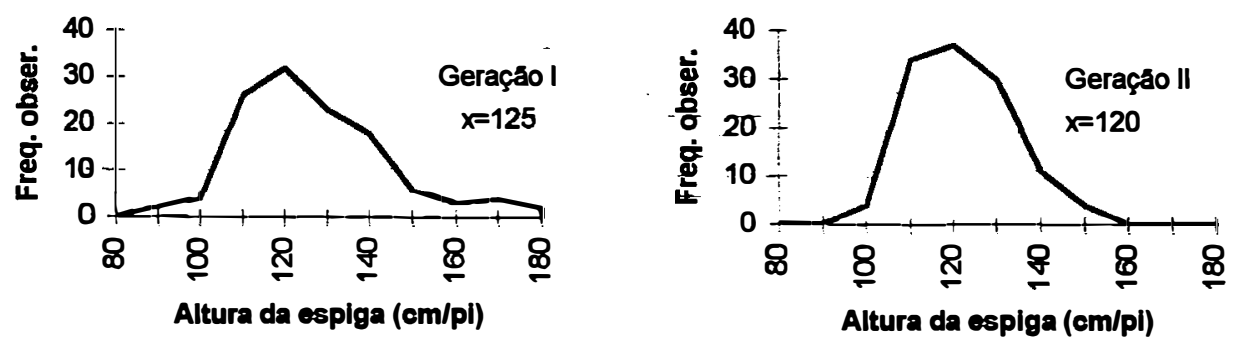

Subpopulação 07
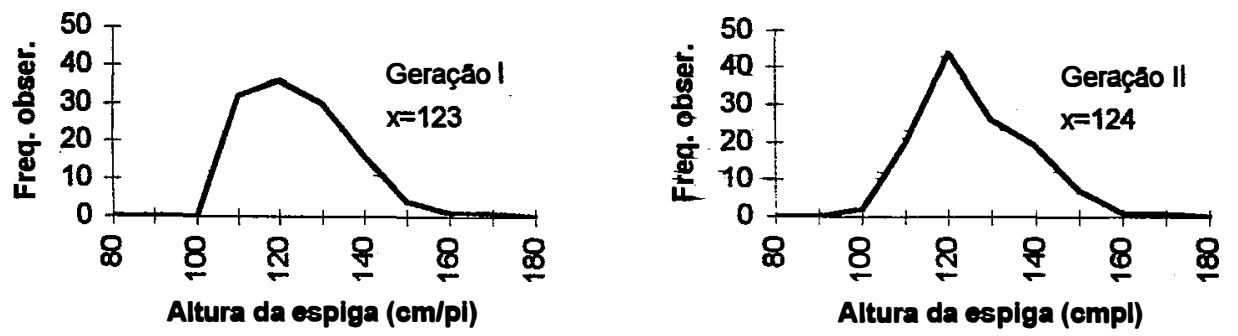

Figura 14 - Distribuição de médias do caráter altura da espiga $(\mathrm{cm} / \mathrm{pl})$ das subpopulações 04, 05, 06 e 07 da população BR-105, nas duas geraçōes de amostragens de tamanho reduzido. 
Subpopulação 08
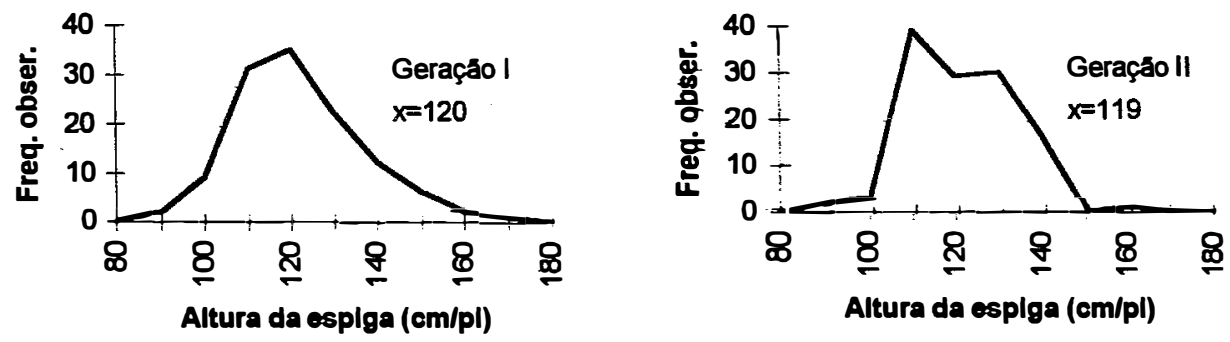

Subpopulação 09
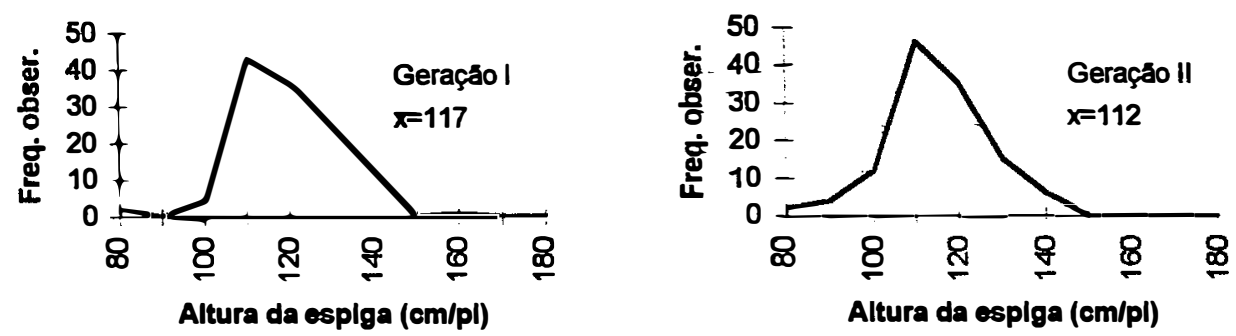

Subpopulação 10
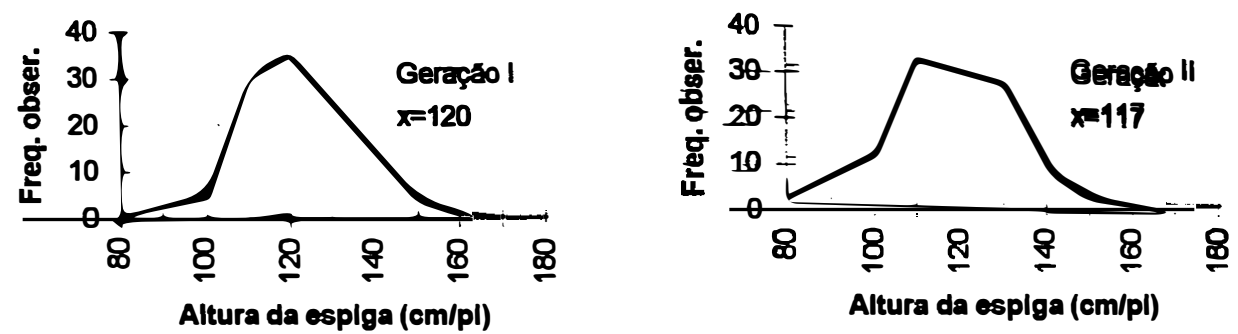

Figura 15 - Distribuição de médias do caráter altura da espiga $(\mathrm{cm} / \mathrm{pl})$ das subpopulações 08,09 e 10 da população BR-105, nas duas gerações de amostragens de tamanho reduzido. 
BR-106

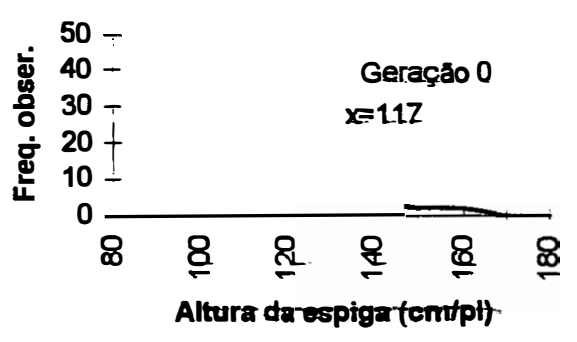

Subpopulação 01
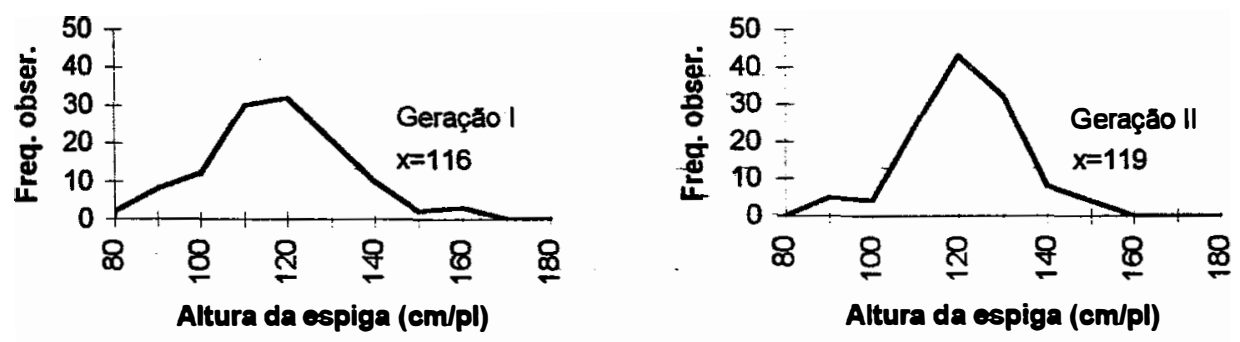

Subpopulação 02
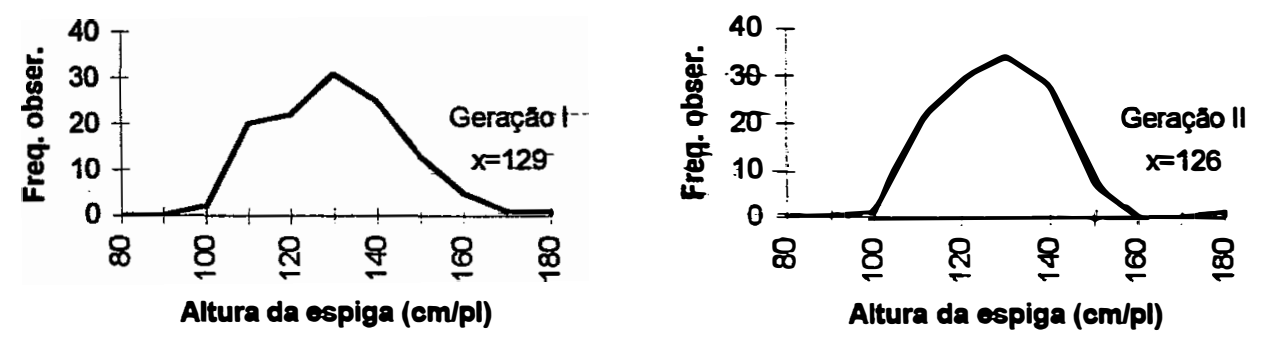

Subpopulação 03
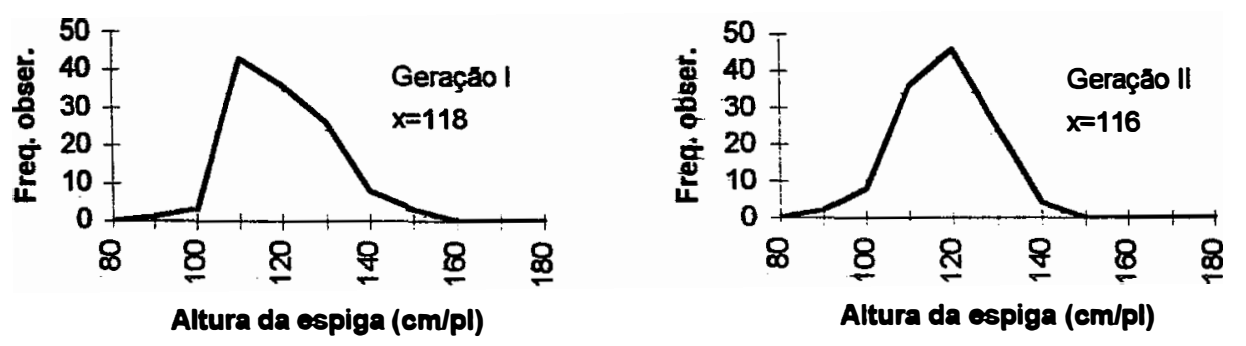

Figura 16 - Distribuição de médias do caráter altura da espiga $(\mathrm{cm} / \mathrm{pl})$ na população BR-106 e nas subpopulações 01, 02 e 03 nas duas gerações de amostragens de tamanho reduzido. 
Subpopulação 04
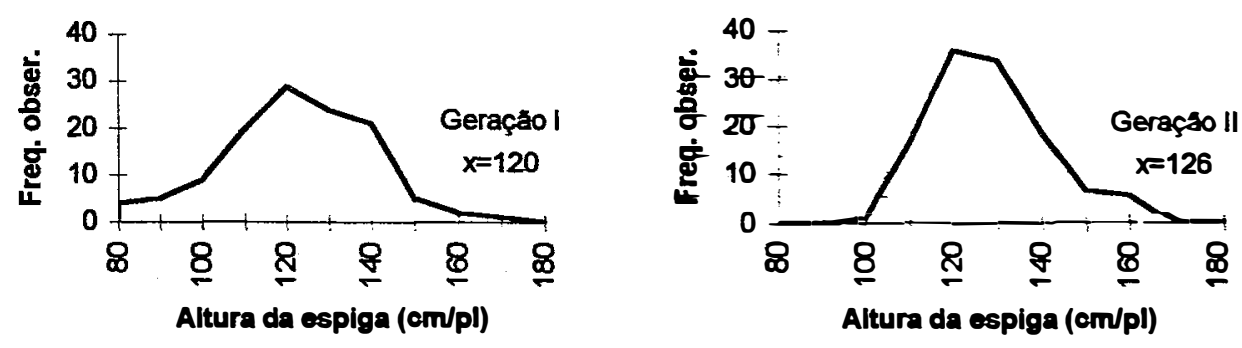

Subpopulação 05
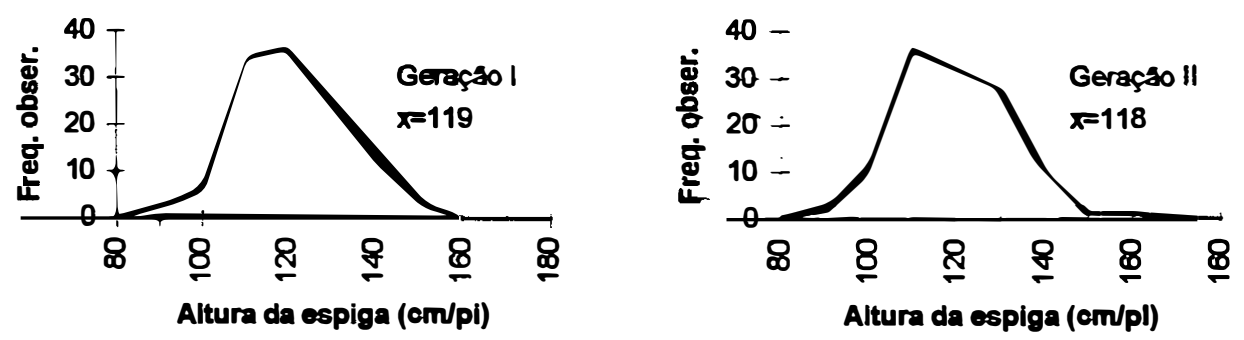

Subpopulação 06
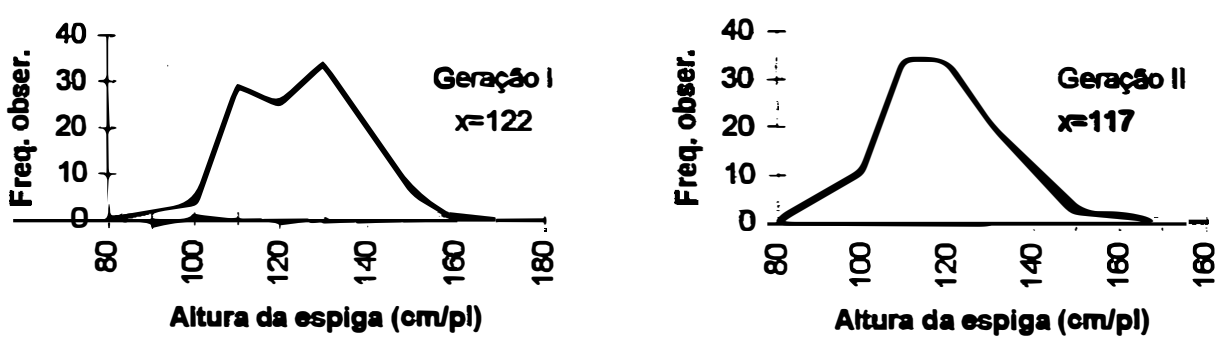

Subpopulação 07
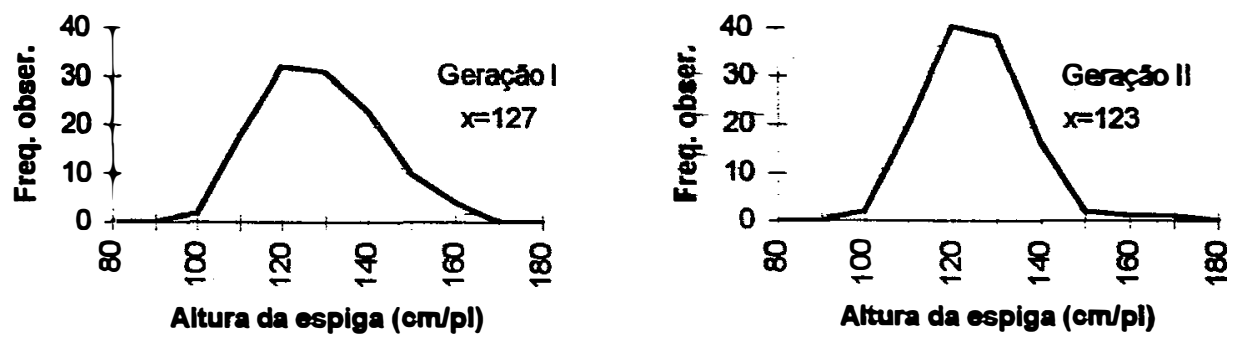

Figura 17 - Distribuição de médias do caráter altura da espiga $(\mathrm{cm} / \mathrm{pl})$ das subpopulações 04, 05, 06 e 07 da população BR-106, nas duas geraçōes de amostragens de tamanho reduzido. 
Subpopulação 08
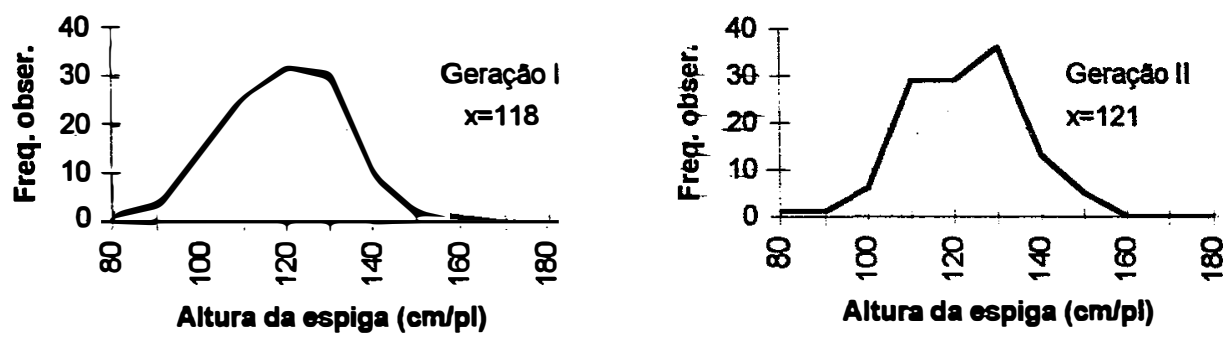

Subpopulação 09
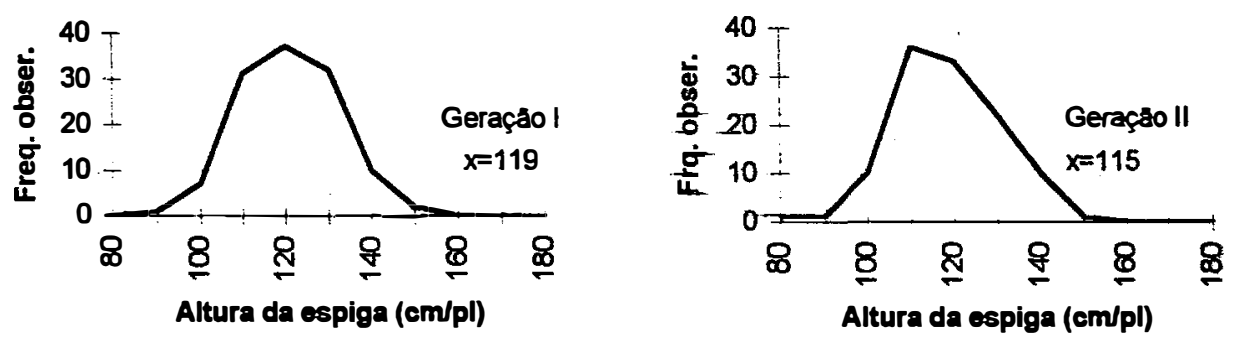

Subpopulação 10
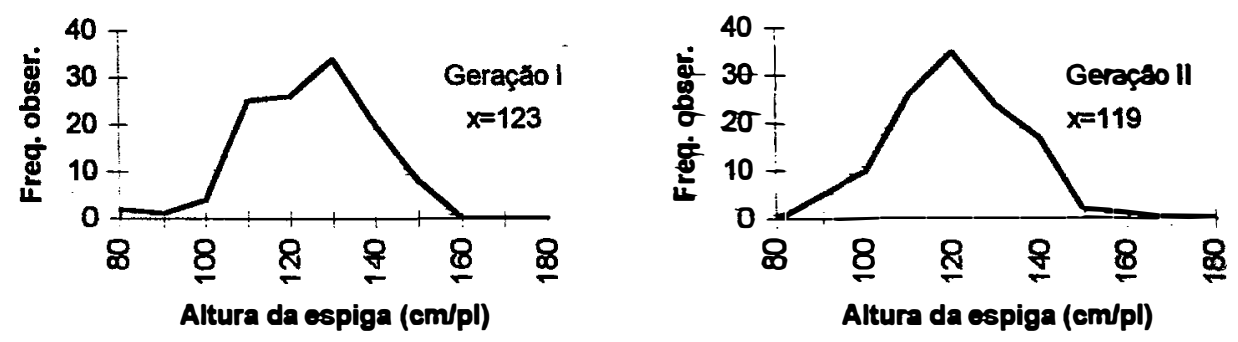

Figura 18 - Distribuição de médias do caráter altura da espiga $(\mathrm{cm} / \mathrm{pl})$ das subpopulações 08, 09 e 10 da população BR-106, nas duas gerações de amostragens de tamanho reduzido. 


\section{ERRATAS}

Pág. vii, $2^{\circ}$ parág., $4^{a}$ linha, onde se lê 'entradas' leia-se 'tratamentos';

Pág. viii, $3^{\circ}$ parág., penúltima linha, onde se lê 'manutenção de bancos germoplasma' leia-se 'manutenção de acessos em bancos de germoplasma;

Pág. ix, título, onde se lê 'POPPULATIONS' leia-se 'POPULATIONS';

Pág. ix, onde se lê 'Advisor' leia-se 'Adviser';

Pág. $x, 1^{\circ}$ parág., $4^{\mathrm{a}}$ linha, onde se lê 'dominace' leia-se 'dominance';

Pág. 1, $3^{\circ}$ parág. $6^{\mathrm{a}}$ linha, onde se lê 'pode ocorrer' leia-se 'podendo ocorrer';

Pág. 9, $1^{\underline{0}}$ parág., $5^{\underline{a}}$ linha, onde se lê 'Holdem \& Williams (1994)' leia-se 'Gale \& Lawrence (1984)';

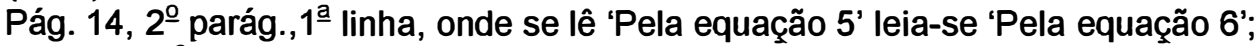

Pág. 23, $1^{\underline{0}}$ parág.,última linha, onde se lê 'Metter \& Gregg, (1973)' leia-se 'Mettler \& Gregg, (1973)';

Pág. 26, $3^{\text {}}$ parág., última linha, onde se lê 'afetando' leia-se 'afeta';

Pág. $31,3^{\circ}$ parág., $2^{\mathrm{a}}$ linha, onde se lê 'foram plantadas lotes' leia-se 'foram instalados em lotes';

Pág. 32, $1^{\circ}$ parág., $1^{\text {a }}$ linha, onde se lê 'plantadas 50 fileiras' leia-se 'utilizadas 50 fileiras';

Pág. 33, 2o parág., $3^{\text {a }}$ linha, onde se lê 'plantas por fileira' leia-se 'plantas por parcela';

Pág. 36, Tabela 3, onde se lê 'Blocos(Locais)' leia-se 'Blocos/Locais';

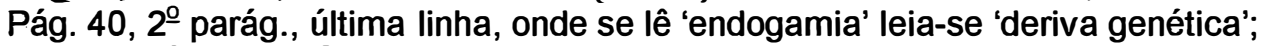

Pág. 46, $3^{\circ}$ parág., $5^{a}$ linha, onde se lê 'sâo muito distantes' leia-se 'são muito contrastantes';

Pág. 49, $2^{0}$ parág., $8^{\mathrm{a}}$ linha, onde se lê 'subpopulação 4 (0,94 esp/pl)' leia-se 'subpopulação 5 (0,94 esp/pl);

Pág. 54, $2^{\circ}$ parág.,14 $4^{a}$ linha, onde se lê 'redução de $1270 \mathrm{Kg} / \mathrm{ha}$ ' leia-se 'redução de $670 \mathrm{Kg} / \mathrm{ha}$ ';

Pág. 54, $2^{\circ}$ parág., $21^{a}$ linha, onde se lê ' $1003 \mathrm{Kg} / \mathrm{ha}$ ' leia-se '1030 Kg/ha';

Pág. 55, $2^{\circ}$ parág., $11^{\mathrm{a}}$ linha, onde se lê ' $-0,36 \mathrm{Kg} / \mathrm{ha}$ ' leia-se '-0,00036 ton/ha';

Pág. 56, $1^{0}$ parág. $7^{\mathrm{a}}$ linha, onde se lê 'contribui' leia-se 'contribuir';

Pág. 56, $2^{\circ}$ parág., $4^{a}$ linha, onde se lê 'subpopulaçãoulaçoes' leia-se 'subpopulações';

Pág. 56, $2^{\circ}$ parág., $6^{\text {a }}$ linha, onde se lê 'aumentou' leia-se 'aumento';

Pág. 58, $2^{\circ}$ parág. , $2^{a}$ linha, onde se lê 'ocorre porque,' leia-se 'é que,';

Pág. 60, $2^{\circ}$ parág., $7^{\underline{a}}$ linha,onde se lê '(452g/pl-subpopulação 1)' leia-se '(452g/pl-subpopulação 7)';

Pág. $60,2^{\circ}$ parág., $7^{\text {a }}$ linha, onde se lê '(465g/pl-subpopulação 7$)^{\prime}$ leia-se '(465g/plsubpopulação 1)';

Pág. $60,2^{\underline{0}}$ parág.,8 $8^{\text {a }}$ linha, onde se lê '(220g/pl-subpopulação 2)' leia-se '(228g/plsubpopulação 10)';

Pág. $65,1^{\underline{a}}$ parág. $4^{\underline{a}}$ linha, onde se lê 'subpopulações 1 e $10^{\prime}$ ' leia-se 'subpopulações 1,2,3,4 e 10;

Pág. $65,1^{\circ}$ parág. $5^{\text {a }}$ linha, onde se lê 'e 8 na ...' leia-se 'e 5,8 e 10 na ... ';

Pág. 65, 1 parág. 6 6 linha, onde se lê 'subpopulações 3 e 4 na...' leia-se 'subpopulações 2 , 3 e as subpopulações 4, 5, 6, 8 e 10 na ...;

Pág. 65, 3ำ parág., 1 linha, onde se lê 'subpopulações 2 e 9' leia-se 'subpopulações 2 e 10';

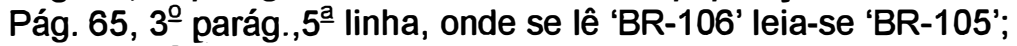

Pág. 74, 4a posição, incluir a referência GALE, J.S.; LAWRENCE, M.J. The decay of variability. In: HOLDEM, J.H.W. ; WILLIAMS,.J.T. Crop genetic resources: conservation e evaluation. George Allen \& Unwin, London. 1984. p.77-101. 